pubs.acs.org/joc

\title{
Design and Synthesis of $\alpha$-Carboxy Phosphononucleosides
}

\author{
Sebastien Debarge, ${ }^{\dagger}$ Jan Balzarini, ${ }^{*}$ and Anita R. Maguire*, ${ }^{\S}$ \\ ${ }^{\dagger}$ Department of Chemistry, Analytical and Biological Chemistry Research Facility, University College Cork, \\ Ireland, ${ }^{*}$ Rega Institute for Medical Research, Katholieke Universiteit Leuven, Minderbroedersstraat, \\ 3000 Leuven, Belgium, and ${ }^{\S}$ Department of Chemistry and School of Pharmacy, Analytical and Biological \\ Chemistry Research Facility, University College Cork, Ireland \\ a.maguire@ucc.ie
}

Received September 3, 2010

\section{Introduction}

Advances in the development of nucleoside analogues as antiviral and specifically anti-HIV and antihepatitis agents have been substantial over the past 25 years. ${ }^{1}$ A number of $2^{\prime}, 3^{\prime}$-dideoxynucleoside analogues have been approved for the treatment of HIV including AZT, ddI, ddC, d4T, ABC and $3 \mathrm{TC}^{2}$ To exhibit antiviral activity, via inhibition of reverse transcriptase, these pro-drugs require in vivo conversion to the corresponding triphosphates. To bypass the initial phosphorylation, which can be rate limiting and therefore problematic in practice, ${ }^{3}$ one of the strategies that has been employed is to use phosphonate analogues of nucleosides as stable nonhydrolyzable isosteres of the natural monophosphate derivatives (Figure 1). While most attention has focused on acyclic nucleoside

(1) (a) De Clercq, E. Future Virol. 2008, 3, 393. (b) De Clercq, E. Int. J. Antimicrob. Agents 2009, 33, 307.

(2) (a) De Clercq, E. J. Clin. Virol. 2004, 30, 115. (b) El Kouni, M. H. Curr. Pharm. Design 2002, 8, 581.

(3) (a) Balzarini, J.; Degrève, B.; De Clercq, E. Nat. Med. 1998, 4, 132. (b) Kukhanova, M.; Krayesvsky, A.; Prusoff, W.; Cheng, Y. C. Curr. Pharm. Design 2000, 6, 585 .

(4) (a) De Clercq, E. Antiviral Res. 2007, 75, 1. (b) De Clercq, E. Biochem. Pharmacol. 2007, 73, 911. (c) Holy, A. Antiviral Res. 2006, 71, 248 and references therein.

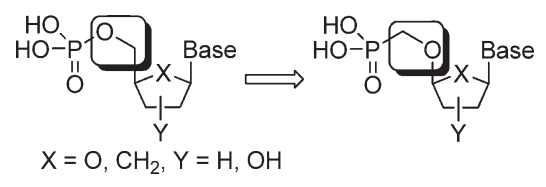

FIGURE 1. Use of phosphonate derivatives as stable nonhydrolyzable isosteres of the nucleoside phosphate.

phosphonates, ${ }^{4}$ some reports have appeared of antiviral activity in phosphonate derivatives of nucleosides and carbocyclic nucleosides (Figure 2). ${ }^{5}$ For example, the phosphonate derivatives 1-7 exhibit antiviral activity. The phosphononucleoside $\mathbf{1}^{5 \mathrm{e}-\mathrm{h}}$ and the carbocyclic analogue $7^{6}$ exhibit anti-HIV activity, while the pyrophosphoryl phosphonate $\mathbf{8}^{6}$ derivative, the triphosphate isostere, is a potent inhibitor of HIV reverse transcriptase. Notably the unnatural enantiomer of $\mathbf{8}$ is the more active compound. Phosphonate analogues of carbocyclic and acyclic nucleosides have also been investigated as cytotoxic agents. $^{7}$

As illustrated in Figure 3, phosphonate derivatives of acyclic nucleosides have also proved successful in antiviral chemotherapy - for example (R)PMPA undergoes diphosphorylation in vivo to form the diphosphate which is a 


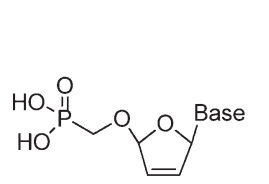

1 Base $=A, d_{4} A P$

2 Base $=\mathrm{T}, \mathrm{d}_{4} \mathrm{TP}$

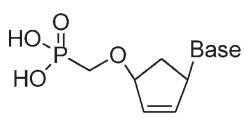

6 Base $=A, 4^{\prime} \mathrm{C}-\mathrm{d}_{4} \mathrm{AP}$ 7 Base $=$ G, $4^{\prime} C-d_{4} G P$

FIGURE 2. Examples of biologically active phosphonate derivatives of nucleosides and carbocyclic nucleosides.

potent inhibitor of HIV reverse transcriptase. A lipophilic pro-drug of (R)PMPA, Viread or Tenofovir Disoproxil has been FDA-approved for treatment of HIV and recently also $\mathrm{HBV} .{ }^{8}$ Notably this drug is marketed in enantiopure form.

The antiviral properties of phosphonoacetic acid 9 (PAA), a strong inhibitor of herpes virus deoxynucleic acid polymerase but ineffective against HIV-1 RT, and phosphonoformic acid $\mathbf{1 0}$ (PFA) a potent inhibitor of RT, have been known for over two decades (Figure 4). ${ }^{9}$ A variety of halogen-substituted analogues of PAA possess greater biological activity than the parent compound with a number of viruses such as HSV-1 and HSV2, while the $\alpha$-keto derivative $\mathbf{1 1}$ is significantly more potent than PAA. The keto diphosphonic acid $\mathbf{1 2}$ is a moderately active RT inhibitor while the methylene derivative $\mathbf{1 3}$ is inactive. ${ }^{9}$

Strategy-Target Design. In the context of the above, it is envisaged that the combination of the structural features of

(5) (a) Mackman, R. L.; Lin, K. Y.; Boojamra, C. G.; Hui, H.; Douglas, J.; Grant, D.; Petrakovsky, O.; Prasad, V.; Ray, A. S.; Cihlar, T. Bioorg. Med. Chem. Lett. 2008, 18, 1116. (b) Mackman, R. L.; Boojamra, C. G.; Prasad, V.; Zhang, L.; Lin, K. Y.; Petrakovsky, O.; Babusis, D.; Chen, J.; Douglas, J.; Grant, D.; Hui, H. C.; Kim, C. U.; Markevitch, D. Y.; Vela, J.; Ray, A.; Cihlar, T. Bioorg. Med. Chem. Lett. 2007, 17, 6785. (c) Mackman, R. L.; Zhang, L.; Prasad, V.; Boojamra, C. G.; Douglas, J.; Grant, D.; Hui, H. C.; Kim, C. U.; Laflamme, G.; Parrish, J.; Stoycheva, A. D.; Swaminathan, S.; Wang, K.; Cihlar, T. Bioorg. Med. Chem. 2007, 15, 5519. (d) Mackman, R. L.; Zhang, L.; Prasad, V.; Boojamra, C. G.; Chen, J.; Douglas, J.; Grant, D.; Laflamme, G.; Hui, H.; Kim, C. U.; Parrish, J.; Stoycheva, A. D.; Swaminathan, S.; Wang, K.; Cihlar, T. Nucleosides Nucleotides 2007, 26, 573. (e) Kim, C. U.; Luh, B. Y.; Martin, J. C. J. Org. Chem. 1991, 56, 2642. (f) Kim, C. U.; Luh, B. Y.; Misco, P. F.; Martin, J. C. Nucleosides Nucleotides 1991, 10, 371. (g) Kim, C. U.; Luh, B. Y.; Martin, J. C. Bioorg. Med. Chem. Lett. 1992, 2, 307. (h) Kim, C. U.; Bronson, J. J.; Ferrara, L. M.; Martin, J. C. Bioorg. Med. Chem. Lett. 1992, 2, 367. (i) Bronson, J. J.; Ferrara, L. M.; Martin, J. C.; Mansuri, M. M. Bioorg. Med. Chem. Lett. 1992, 2, 685. (j) Wu, T.; Froeyen, M.; Kempeneers, V.; Pannecouque, C.; Wang, J.; Busson, R.; De Clercq, E.; Herdewijn, P. J. Am. Chem. Soc. 2005, 127, 5056. (k) Khandazhinskaya, A. L.; Shirokova, E. A.; Skoblov, Y. S.; Victorova, L. S.; Goryunova, L. Y.; Beabealashvilli, R. S.; Pronyaeva, T. R.; Fedyuk, N. V.; Zolin, V. V.; Pokrovsky, A. G.; Kukhanova,

M. K. J. Med. Chem. 2002, 45, 1284.

(6) (a) Coe, D. M.; Orr, D. C.; Roberts, S. M.; Storer, R. J. Chem. Soc., Perkin Trans. 1 1991, 3378. (b) Coe, D. M.; Hilbert, H.; Noble, S. A.; Peel, M. R.; Roberts, S. M.; Storer, R. J. Chem. Soc., Chem. Commun. 1991, 312. (c) Coe, D. M.; Roberts, S. M.; Storer, R. J. Chem. Soc., Perkin Trans. 11992 , 2695. (d) Merlo, V.; Roberts, S. M.; Storer, R.; Bethell, R. C. J. Chem. Soc., Perkin Trans. 1 1994, 1477. (e) Coe, D. M.; Garofalo, A.; Roberts, S. M.; Storer, R.; Thorpe, A. J. J. Chem. Soc., Perkin Trans. 1 1994, 3061. (f) Drake, A. F.; Garofalo, A.; Hillman, J. M. L.; Merlo, V.; McCague, R.; Roberts, S. M. J. Chem. Soc., Perkin Trans. 1 1996, 2739. (g) Hamilton, C. J.; Roberts, S. M.; Shipitsin, A. Chem. Commun. 1998, 1087. (h) Hamilton, C. J.; Roberts, S. M. J. Chem. Soc., Perkin Trans. 1 1999, 1051. (i) Shipitsin, A. V.; Victorova, L. S.; Shirokova, E. A.; Dyatkina, N. B.; Goryunova, L. E.; Beabealashvilli, S. S.; Hamilton, C. J.; Roberts, S. M.; Krayevsky, A. J. Chem. Soc., Perkin Trans. 1 1999, 1039.

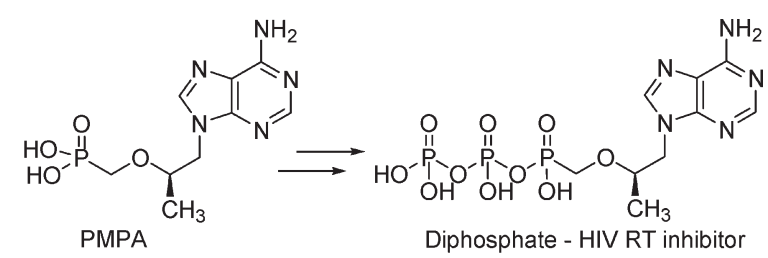<smiles>[3H]P(=O)(CO[C@@H](C)Cn1cnc2c(N)ncnc21)OCOC(=O)OC(C)CC</smiles>

FIGURE 3. Viread, Tenofovir Disoproxil-FDA approved prodrug.<smiles>O=C(O)CP(=O)(O)O</smiles><smiles>O=C(O)C(=O)P(=O)(O)O</smiles>

FIGURE 4. Phosphonoacetic acid, phosphonoformic acid and derivatives.

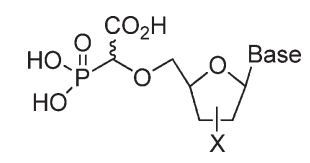

FIGURE 5. Target compounds.

phosphononucleosides and PAA would provide novel compounds (Figure 5), in which the phosphonate bears an $\alpha$ carboxylic acid substituent, with potential as antiviral agents. Interestingly, attachment of PAA and PFA to the $5^{\prime}-O$ or $N^{4}$ position of $3 \mathrm{TC}$ or to the $5^{\prime}$-OH group of AZT has been described, but in each case, the anti-HIV-1 activity in vitro was less than that of 3TC. ${ }^{10}$

While the majority of research with phosphononucleosides has been conducted with simple $\mathrm{CH}_{2} \mathrm{PO}(\mathrm{OH})_{2}$ substituents, there have been some reports of derivatives bearing substituents geminal to the phosphonic acid group. Investigation of

(7) (a) Elliott, R. D.; Rener, G. A.; Riordan, J. M.; Secrist, J. A., III; Bennett, L. L.; Parker, W. B.; Montgomery, J. A. J. Med. Chem. 1994, 37, 739. (b) De Clercq, E.; Andrei, G.; Balzarini, J.; Hatse, S.; Liekens, S.; Naesens, L.; Neyts, J.; Snoeck, R. Nucleosides Nucleotides 1999, 18, 759. (c) Liekens, S.; Neyts, J.; De Clercq, E.; Verbeken, E.; Ribatti, D.; Presta, M. Cancer Res. 2001, 61, 5057. (d) Bubenik, M.; Rej, R.; Nguyen-Ba, N.; Attardo, G.; Ouellet, F.; Chan, L. Bioorg. Med. Chem. Lett. 2002, 12, 3063. (8) De Clercq, E. Med. Chem. Res. 2004, 13, 439.

(9) (a) McKenna, C. E.; Levy, J. N. J. Chem. Soc., Chem. Commun. 1989, 4, 246. (b) McKenna, C. E.; Khawli, L. A.; Bapat, A.; Harutunian, V.; Cheng, Y. C. Biochem. Pharmacol. 1987, 36, 3103. (c) Erikson, B.; Oberg, B.; Wahren, G. Biochem. Biophys. Acta 1982, 696, 115. (d) McKenna, C. E.; Khare, A.; Ju, J. Y.; Li, Z. M.; Duncan, G.; Cheng, Y. C.; Kilkuskie, R. Phosphorus, Sulfur Silicon 1993, 76, 139.

(10) Charvet, A. S.; Camplo, M.; Faury, P.; Graciet, J. P.; Mourier, N.; Chermann, J. C.; Kraus, J. L. J. Med. Chem. 1994, 37, 2216. 
<smiles>CN(O)OP(=O)(O)OP(=O)(O)OP(=O)(O)O</smiles><smiles>CCONC(=O)CC(O)(CC(=O)O)C(=O)O</smiles>

citrate isostere 14

\section{FIGURE 6}

$\alpha$-fluoro and $\alpha, \alpha$-difluorophosphonate analogues of nucleosides has been reported as these derivatives are closer phosphate analogues, in both electronic and structural terms, to phosphates. ${ }^{11,12}$ Synthesis of $\alpha$-hydroxy and $\alpha$-aminophosphonate nucleoside derivatives has also been described. ${ }^{13}$ However, to the best of our knowledge, synthesis of phosphononucleosides with an $\alpha$-carboxylic acid moiety has not been reported.

It was envisaged that the novel phosphononucleosides illustrated in Figure 5 bearing a carboxylic acid moiety could act as analogues of a nucleoside diphosphate. Gilbert and co-workers have synthesized the citrate derivatives of nucleosides $\mathbf{1 4}$ as potential triphosphate isosteres (Figure 6) ${ }^{14}$ but found that they were inactive, indicating that the citrate isostere is not a good replacement for the triphosphate group in this case. In 2007, Vederas reported the synthesis of nucleoside dicarboxylates as potential mimics of nucleoside diphosphates. ${ }^{15}$

Strategy - Synthesis. The most commonly employed method for the attachment of phosphonate moieties to nucleoside derivatives involves nucleophilic displacement of precursors such as (RO) $)_{2} \mathrm{OPCH}_{2} \mathrm{OTs}$ with an alkoxide anion under strongly basic conditions. ${ }^{16}$ However, the harsh conditions associated with this method is limiting in terms of the substrate range which can tolerate the high $\mathrm{pH}$. In the context of our ongoing program of research in rhodium and copper catalyzed transformation of $\alpha$-diazocarbonyl derivatives, ${ }^{17}$ we devised an alternative attractive synthetic strategy. We envisaged that transition metal catalyzed $\mathrm{O}-\mathrm{H}$ insertion reactions with diazophosphonate derivatives could be employed to attach phosphonate moieties to nucleoside derivatives under mild conditions, at neutral $\mathrm{pH}$ (Figure 7).

Moody and co-workers have extensively investigated $\mathrm{O}-\mathrm{H}$ insertion reactions of $\alpha$-diazophosphonate derivatives, ${ }^{18}$ and

(11) Wnuk, S. F.; Robins, M. J. J. Am. Chem. Soc. 1996, 118, 2519.

(12) (a) Romanenko, V. D.; Kukhar, V. P. Chem. Rev. 2006, 106, 3868. (b) Chen, W.; Flavin, M. T.; Filler, R.; Xu, Z. Q. Tetrahedron Lett. 1996, 37, 8975. (c) Chen, W.; Flavin, M. T.; Filler, R.; Xu, Z. Q. J. Chem. Soc., Perkin Trans. 1 1998, 3979. (d) Matulic-Adamic, J.; Haeberli, P.; Usman, N. J. Org. Chem. 1995, 60, 2563.

(13) (a) Kralikova, S.; Budesinsky, M.; Masojidkova, M.; Rosenberg, I. Tetrahedron Lett. 2000, 41, 955. (b) Chen, X.; Wiemer, A. J.; Hohl, R. J.; Wiemer, D. F. J. Org. Chem. 2002, 67, 9331. (c) Chen, X.; Wiemer, D. F. J. Org. Chem. 2003, 68, 6108 .

(14) (a) Weaver, R.; Gilbert, I. H. Tetrahedron 1997, 53, 5537. (b) Weaver, R.; Gilbert, I. H.; Mahmood, N.; Balzarini, J. Bioorg. Med. Chem. Lett. 1996, 6,2405 .

(15) Boudreau, M. A.; Vederas, J. C. Org. Biomol. Chem. 2007, 5, 627.

(16) (a) Pérez-Pérez, M. J.; Rozenski, J.; Busson, R.; Herdewijn, P. J. Org.

Chem. 1995, 60, 1531. (b) Holy, A.; Rosenberg, I. Collect. Czech. Chem.

Commun. 1982, 47, 3447. (c) Coe, D. M.; Orr, D. C.; Roberts, S. M.; Storer,

R. J. Chem. Soc., Perkin Trans. 1 1991, 12, 3378.

(17) O'Keeffe, S.; Harrington, F.; Maguire, A. R. Synlett 2007, 15, 2367.

(18) (a) Miller, D. J.; Moody, C. J. Tetrahedron 1995, 51, 10811. (b) Cox,

G. G.; Miller, D. J.; Moody, C. J.; Sie, E. R. H. H.; Kulagowski, J. J.

Tetrahedron 1994, 50, 3195. (c) Cox, G. G.; Kulagowski, J. J.; Moody, C. J.;

Sie, E. R. H. B. Synlett 1992, 975 and references therein.
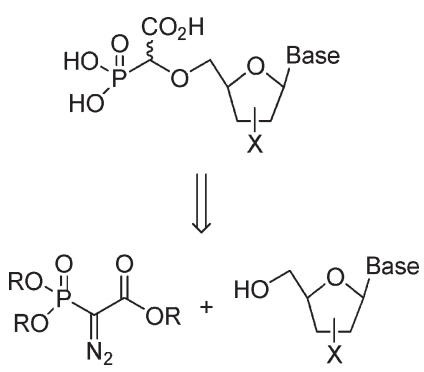

FIGURE 7. Transition metal catalyzed process-neutral and mild conditions.<smiles></smiles>

$\begin{array}{lll}\text { 15a,b Base= } & \text { Thymine } a, X=O H \\ 16 a, b & \text { Uracil b, } \mathrm{X}=\mathrm{H} \\ 17 \mathbf{a}, \mathbf{b} & \text { Cytosine } \\ 18 \mathbf{a}, \mathbf{b} & \text { Adenine } \\ \text { 19a,b } & \text { Guanine }\end{array}$

FIGURE 8. Target compounds.

some examples of $\mathrm{O}-\mathrm{H}$ insertion reactions with more highly functionalized alcohols have been reported. ${ }^{19} \mathrm{O}-\mathrm{H}$ insertion has also been previously reported with some phenol derivatives and triethyl diazophosphonoacetate. ${ }^{20}$ However, to the best of our knowledge, we are not aware of any reports of transition metal catalyzed $\mathrm{O}-\mathrm{H}$ insertion reactions of diazophosphonates with nucleosides, or carbocyclic analogues. At the outset of the project, catalyst inhibition through co-ordination with the heterocyclic bases was envisaged as a potential complication; however, this did not prove to be a significant problem in practice, as judicious protecting group selection overcame catalyst poisoning. Kim et al. reported intramolecular $\mathrm{C}-\mathrm{H}$ insertion of diazomalonates with nucleosides, ${ }^{21}$ indicating that generation and reaction of rhodium carbenoids in the presence of nucleosides is possible.

Herein, we report our results concerning the successful application of this strategy to the synthesis of a series of phosphononucleosides bearing an $\alpha$-carboxylic acid moiety, envisaged as potential diphosphate mimics. A general route to these compounds, involving a rhodium catalyzed $\mathrm{O}-\mathrm{H}$ insertion reaction with trimethyl diazophosphonoacetate and suitably protected nucleosides has been developed. Using appropriate protecting groups, efficient $\mathrm{O}-\mathrm{H}$ insertion at the $5^{\prime}$-hydroxyl substituent could be achieved.

\section{Results and Discussion}

Chemistry. The target compounds 15a,b-19a,b (Figure 8), including both nucleosides and their $2^{\prime}$-deoxy analogues, were selected for investigation. The commercially available thymidine, uridine, 5-methyluridine, 2 '-deoxyuridine, cytidine,

(19) (a) Pansare, S. V.; Jain, R. P.; Bhattacharyya, A. Tetrahedron Lett. 1999, 40, 5255. (b) Kettle, J. G.; Faull, A. W.; Fillery, S. M.; Flynn, A. P.; Hoyle, M. A.; Hudson, J. A. Tetrahedron Lett. 2000, 41, 6905. (c) Nelson, T. D.; Song, Z. J.; Thompson, A. S.; Zhao, M. Z.; DeMarco, A.; Reamer, R. A.; Huntington, M. F.; Grabowski, E. J. J.; Reider, P. J. Tetrahedron Lett. 2000, 41, 1877.

(20) Shah, A.; Font, J. L.; Miller, M. J.; Ream, J. E.; Walker, M. C.; Sikorski, J. A. Bioorg. Med. Chem. 1997, 5, 323.

(21) Lim, J.; Choo, D. J.; Kim, Y. H. Chem. Commun. 2000, 553. 
2'-deoxycytidine, adenosine, 2 -deoxyadenosine and guanosine were employed as starting materials. These targets were selected as, in addition to the primary $5^{\prime}-\mathrm{OH}$ group, they contain at least one further alcohol substituent (at C-3', and in addition at $\mathrm{C}-2^{\prime}$ in some cases) and thereby demonstrate the ability to selectively attach the phosphonate group to the primary alcohol at C-5' through appropriate use of protecting groups. In all cases the phosphonates are formed as an essentially equimolar mixture of the two epimers, thereby enabling biological evaluation of the two epimers.

A series of $\alpha$-diazophosphonoacetates 20-22 were prepared for evaluation as precursors for the $\mathrm{O}-\mathrm{H}$ insertions. In addition to the efficiency of the $\mathrm{O}-\mathrm{H}$ insertion processes, which is influenced by the nature of the substituents, the ease of deprotection to reveal the phosphononuceloside was a consideration. The tribenzyl derivative $\mathbf{2 2}$ was explored with a view to cleavage via hydrogenolysis under neutral conditions following $\mathrm{O}-\mathrm{H}$ insertion. Trimethyl diazophosphonoacetate $\mathbf{2 0}$ was found to be the most suitable precursor in the $\mathrm{O}-\mathrm{H}$ insertion reaction, resulting in efficient $\mathrm{O}-\mathrm{H}$ insertion and the resulting trimethyl phosphonate ester was readily cleaved to reveal the fully deprotected phosphonic acids as discussed below. The $\mathrm{O}-\mathrm{H}$ insertion proceeds well with the triethyl derivative $\mathbf{2 1}$ but the deprotection is less clean, while with the more sterically hindered tribenzyl derivative 22 the rate of the $\mathrm{O}-\mathrm{H}$ insertion is decreased resulting in lower yields. Diazo transfer to trimethyl phosphonoacetate with tosyl azide and potassium carbonate in acetonitrile afforded the corresponding trimethyl diazophosphonoacetate $\mathbf{2 0}$ in good yields (ca. 80\%) after purification. ${ }^{22}$ The key $\mathrm{O}-\mathrm{H}$ insertion reactions were carried out using the suitably protected nucleosides bearing a free $5^{\prime}$-hydroxyl group, trimethyl diazophosphonoacetate $\mathbf{2 0}$ and rhodium acetate $(\sim 1 \mathrm{~mol} \%)$ as catalyst.

Synthesis of Protected Nucleoside Derivatives. The nucleoside precursors are challenging substrates for rhodium catalyzed $\mathrm{O}-\mathrm{H}$ insertion reactions bearing both primary and secondary hydroxyl groups, potentially leading to regioisomeric products, and an electron rich purine or pyrimidine base which potentially can coordinate to the catalyst leading to poisoning or indeed undergo reaction with the carbene intermediates. Thus, judicious use of protecting groups to selectively block the secondary hydroxyl groups and prevent competing reaction at the base is required to results in efficient $\mathrm{O}-\mathrm{H}$ insertion at $\mathrm{C}-5^{\prime}$. Perbenzoylated nucleosides bearing free $5^{\prime}$-hydroxyl groups were identified as key precursors for the $\mathrm{O}-\mathrm{H}$ insertion reaction. Thus, we envisioned the synthetic sequence outlined in Scheme 1.

The synthetic approach to the protected nucleoside precursors involved the following sequence based on known literature procedures: (i) selective silylation of $5^{\prime}-\mathrm{OH}$ of nucleosides using the tert-butyldimethylsilyl (TBDMS) group, ${ }^{23}$ (ii) perbenzoylation of the TBDMS derivatives with an excess of benzoyl chloride, 4- $N, N$-(dimethylamino)pyridine (DMAP) and triethylamine and (iii) deprotection of the TBDMS group using a mixture of TFA/ $\mathrm{H}_{2} \mathrm{O} / \mathrm{THF}(1: 1: 4)$ (Scheme 2$) .{ }^{24}$ 652.

(22) Koskinen, A. P.; Munoz, L. J. Chem. Soc., Chem. Commun. 1990,

(23) Olgivie, K. K.; Schifman, A. L.; Penney, C. L. Can. J. Chem. 1979, 57,2230 .

(24) Zhu, X. F.; Scott, A. I. Synth. Commun. 2008, 38, 1346.

\section{SCHEME 1. Synthetic Strategy}

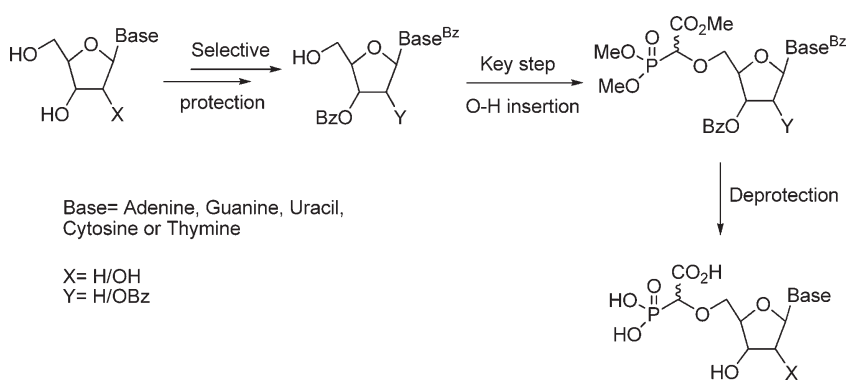

This strategy has been applied to thymidine and 5-methyluridine, uridine, cytidine, adenosine and their $2^{\prime}$-deoxy analogues as summarized in Scheme 2 and Table 1.

Excellent yields were obtained in this sequence with thymidine and 5-methyluridine, uridine, adenosine and their 2'deoxy analogues. The overall yields of the selective protection/deprotection for cytidine and its $2^{\prime}$-deoxy analogue were lower due to the perbenzoylation reaction step which led to the 4- $N, N$-dibenzoylation side product as an impurity, which could be removed by chromatography.

In the 5-methyluridine series, compounds $\mathbf{2 5 a}$ and $\mathbf{2 6 a}$ are novel, whereas in the $2^{\prime}$-deoxyuridine series, compound $29 \mathbf{b}$ is novel while all the other compounds synthesized have been previously reported in literature. This work provided a useful series of orthogonally protected nucleosides with some compounds which have not been previously described.

During later work focused on the guanosine series (see below), we discovered that this synthetic sequence leading to the desired compounds 26a, b, 30a, b, 34a, b, 38a, b could potentially have been simplified to a three step, one purification procedure following the work from Scott et al. ${ }^{24}$ with expected increases in overall yield as a result.

Due to complications in the $\mathrm{O}-\mathrm{H}$ insertion reaction of guanosine derivatives, a number of differently protected guanosine precursors were synthesized. First, the $N$-2-amine of guanosine was protected as the isobutyryl amide $\mathbf{3 9}$ by the "transient protection" method developed by Jones and coworkers ${ }^{25,26}$ and the $2^{\prime}$ - and $3^{\prime}$-hydroxy groups were then protected as an isopropylidene acetal $\mathbf{4 0}$ by reaction with 2 , 2-dimethoxypropane under acidic catalysis (Scheme 3). ${ }^{27} \mathrm{As}$ the guanosine derivative $\mathbf{4 0}$ was totally insoluble in organic solvents, it did not react during the $\mathrm{O}-\mathrm{H}$ insertion reaction.

Accordingly we decided to explore differently protected guanosine derivatives such as $\mathbf{4 3}$ in which the $2^{\prime}$ - and $3^{\prime}$ hydroxyl groups are benzoylated as illustrated below (Scheme 4). ${ }^{28}$ However, once again the guanosine deriviative 43 was insoluble in benzene or dichloromethane at reflux and no $\mathrm{O}-\mathrm{H}$ insertion reaction could be observed.

A further protection strategy to enhance the solubility of guanosine derivatives suitable for the $\mathrm{O}-\mathrm{H}$ insertion reaction was explored. Guanosine was first protected by $N, N$ dimethylaminomethylene at the $N$-2-amine of guanine by reaction with $N, N$-dimethylformamide dimethyl acetal in

(25) Ti, G. S.; Gaffney, B. L.; Jones, R. A. J. Am. Chem. Soc. 1982, 104, 1316.

(26) McLaughlin, L. W.; Piel, N.; Hellmann, T. Synthesis 1985, 3, 322.

(27) Eisenfuhr, A.; Arora, P. S.; Sengle, G.; Takaoka, L. R.; Nowick, J. S.; Famulok, M. Bioorg. Med. Chem. 2003, 11, 235.

(28) Mourani, R.; Damha, M. J. Nucleosides, Nucleotides Nucleic Acids 2006, 25, 203. 
SCHEME 2. Selective Protection of Thymidine, Uridine, Cytidine, and Adenosine ${ }^{a}$

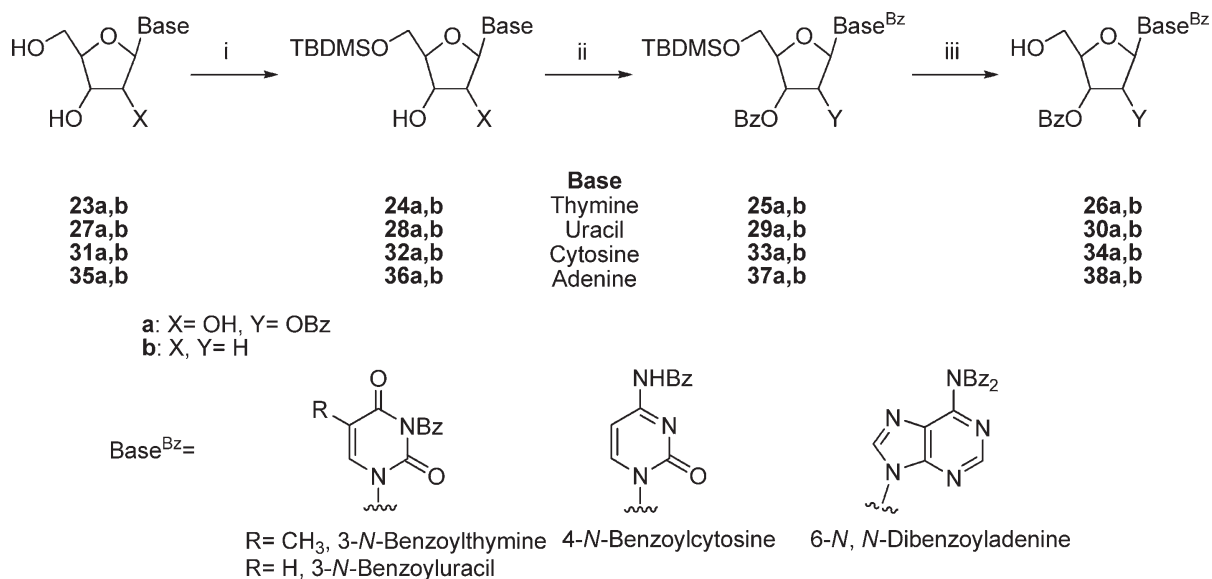

${ }^{a}$ Reagents and conditions: (i) TBDMSCl, Imidazole, DMF, rt, overnight. (ii) $\mathrm{BzCl}$, DMAP, $\mathrm{NEt}_{3}, \mathrm{CH}_{2} \mathrm{Cl}_{2}$, rt, overnight. (iii) THF/TFA/H $\mathrm{H}_{2} \mathrm{O}$ (4:1:1), rt, $3 \mathrm{~h}$.

TABLE 1. Preparation of Nucleosides 26a:b, 30a:b, 34a:b, and 38a:b

\begin{tabular}{|c|c|c|c|c|c|c|}
\hline substrate & $X$ & Y & $\begin{array}{l}\text { conditions }^{a}(\mathrm{i}) \\
\text { product }(\%)^{b}\end{array}$ & $\begin{array}{l}\text { conditions }^{a}(\mathrm{ii}) \\
\text { product }(\%)^{b}\end{array}$ & $\begin{array}{l}\text { conditions }^{a}(\mathrm{iii}) \\
\text { product }(\%)^{b}\end{array}$ & $\begin{array}{c}\text { product } \\
(\text { overall yield } \%)^{b}\end{array}$ \\
\hline $23 \mathbf{a}$ & $\mathrm{OH}$ & $\mathrm{OBz}$ & 24a (85) & $\mathrm{A}, \mathbf{2 5 a}(81)$ & 4 h, 26a (89) & 26a (61) \\
\hline 23b & $\mathrm{H}$ & $\mathrm{H}$ & $\mathbf{2 4 b}(92)$ & B, 25b (89) & 3 h, 26b (92) & $26 b(75)$ \\
\hline $27 \mathbf{a}$ & $\mathrm{OH}$ & $\mathrm{OBz}$ & 28a (93) & A, 29a (75) & 4 h, 30a (88) & 30a (61) \\
\hline $27 \mathrm{~b}$ & $\mathrm{H}$ & $\mathrm{H}$ & $28 b(69)$ & B, 29b (76) & $5 \mathrm{~h}, \mathbf{3 0 b}(91)$ & 30b (48) \\
\hline $31 \mathrm{a}$ & $\mathrm{OH}$ & $\mathrm{OBz}$ & 32a (91) & $\mathrm{C}, \mathbf{3 3} \mathbf{a}(64)^{c}$ & $4 \mathrm{~h}, \mathbf{3 4 a}(53)$ & 34a (33) \\
\hline $31 \mathrm{~b}$ & $\mathrm{H}$ & $\mathrm{H}$ & 32b (91) & D, 33b (48) & $3 \mathrm{~h}, \mathbf{3 4 b}(77)$ & 34b (34) \\
\hline $35 \mathbf{a}$ & $\mathrm{OH}$ & $\mathrm{OBz}$ & 36a (68) & E, 37a (66) & $3 \mathrm{~h}, \mathbf{3 8 a}(88)$ & 38a (39) \\
\hline $35 \mathrm{~b}$ & $\mathrm{H}$ & $\mathrm{H}$ & $36 \mathbf{b}(72)$ & $\mathrm{F}, \mathbf{3 7 b}(75)$ & 5 h, $\mathbf{3 8 b}(89)$ & $\mathbf{3 8 b}(48)$ \\
\hline
\end{tabular}

${ }^{a}$ Reaction conditions: (i) TBDMSCl (1.05 equiv), Imidazole (2 equiv), DMF, 12 h. (ii) (Method A) $\mathrm{BzCl}$ ( 5 equiv), NEt ${ }_{3}$ ( 6 equiv), DMAP ( 0.5 equiv), $\mathrm{CH}_{2} \mathrm{Cl}_{2}, 12 \mathrm{~h}$. (Method B) BzCl (3 equiv), $\mathrm{NEt}_{3}$ (4 equiv), DMAP (0.3 equiv), $\mathrm{CH}_{2} \mathrm{Cl}_{2}, 12 \mathrm{~h}$. (Method C) BzCl (4 equiv), $\mathrm{NEt}_{3}$ ( 4 equiv), DMAP (0.4 equiv), $\mathrm{CH}_{2} \mathrm{Cl}_{2}, 12$ h. (Method D) $\mathrm{BzCl}$ (2.4 equiv), $\mathrm{NEt}_{3}$ (2.4 equiv), DMAP (0.2 equiv), $\mathrm{CH}_{2} \mathrm{Cl}_{2}, 12$ h. (Method E) BzCl (8 equiv), $\mathrm{NEt}$ ( $(8$ equiv), DMAP (0.8 equiv), $\mathrm{CH}_{2} \mathrm{Cl}_{2}, 12$ h. (Method F) BzCl (6 equiv), $\mathrm{NEt}_{3}$ (6 equiv), DMAP (0.6 equiv), $\mathrm{CH}_{2} \mathrm{Cl}_{2}, 12$ h. (iii) TFA/ $\mathrm{H}_{2} \mathrm{O} / \mathrm{THF}$ (1:1:4). ${ }^{b} \mathrm{After}$ purification by flash chromatography. ${ }^{c}$ Contains around $20 \%$ of impurity.

SCHEME 3. Selective Protection of Guanosine ${ }^{a}$<smiles></smiles>

${ }^{a}$ Reagents and conditions: (i) (1) TMSCl, pyridine, rt, $2 \mathrm{~h}$; (2) Isobutyryl chloride, rt, $3 \mathrm{~h}$; (3) conc. $\mathrm{NH}_{4} \mathrm{OH}, \mathrm{rt}, 15$ min. (ii) 2,2'-dimethoxypropane, p-toluenesulfonic acid, DMF, rt, overnight.

methanol to give 2-(N,N-dimethylaminomethylene) guanosine $44 .^{29}$ This product was then treated with tert-butyldimethylsilyl chloride in pyridine followed by benzoyl chloride

(29) Sheppard, T. L.; Rosenblatt, A. T.; Breslow, R. J. Org. Chem. 1994, 59,7243 .
SCHEME 4. Selective Protection of Guanosine ${ }^{a}$<smiles>CC(C)C(=O)Nc1nc2c(ncn2C2OC(CO)C(O)C2O)c(=O)[nH]1</smiles><smiles>CC(C)C(=O)Nc1nc2c(ncn2C2OC(CO)C(OC(=O)c3ccccc3)C2OC(C)(C)C)c(=O)[nH]1</smiles>

${ }^{a}$ Reagents and conditions: (i) (1) TMSCl, Pyridine, rt, 2 h; (2) Isobutyryl chloride, rt, $3 \mathrm{~h}$; (3) conc. $\mathrm{NH}_{4} \mathrm{OH}$, rt, 15 min. (ii) Trityl chloride, DMAP, pyridine, rt, overnight. (iii) $\mathrm{BzCl}$, DMAP, $\mathrm{NEt}_{3}, \mathrm{CH}_{2} \mathrm{Cl}_{2}$, rt, overnight. (iv) p-Toluenesulfonic acid, $\mathrm{CH}_{2} \mathrm{Cl}_{2}, \mathrm{rt}, 15 \mathrm{~min}$.

to give compound 45. Finally the $5^{\prime}$-TBDMS group was removed using a mixture of TFA $/ \mathrm{H}_{2} \mathrm{O} / \mathrm{THF}$ (1:1:4) to afford compound 46 (Scheme 5). While the protected guanosine 46 proved more soluble than the other derivatives, it still did not lead to successful $\mathrm{O}-\mathrm{H}$ insertion as discussed below.

Compounds 45 and $\mathbf{4 6}$ are novel and may prove useful synthetically in other transformations. 


\section{SCHEME 5. Selective Protection of Guanosine ${ }^{a}$}
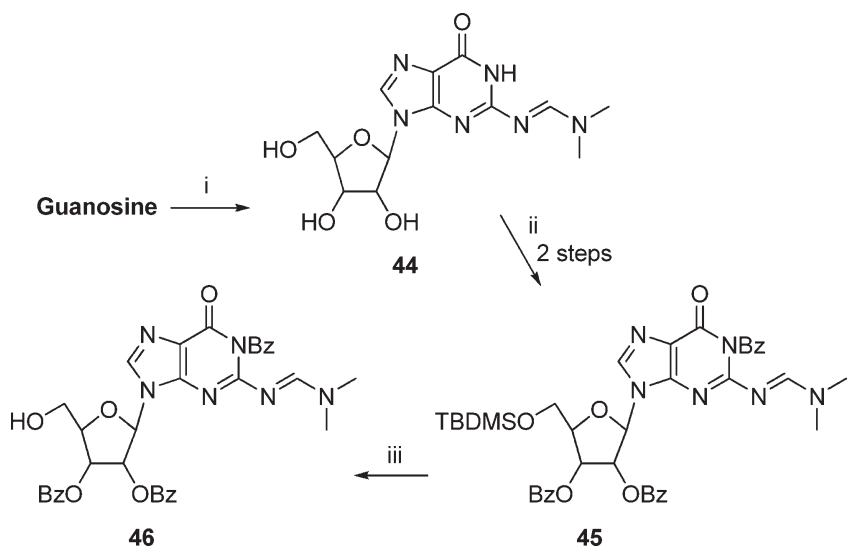

${ }^{a}$ Reagents and conditions: (i) $\mathrm{Me}_{2} \mathrm{NCH}(\mathrm{OMe})_{2}, \mathrm{MeOH}$, rt, overnight. (ii) (1) TBDMSCl, DMAP, pyridine, rt, overnight; (2) $\mathrm{BzCl}$, rt, overnight. (iii) $\mathrm{TFA} / \mathrm{H}_{2} \mathrm{O} / \mathrm{THF}(1: 1: 4)$, rt, $3 \mathrm{~h}$.

O-H Insertion Reactions. With the series of protected nucleoside precursors bearing a free $5^{\prime}$-hydroxyl group in hand, rhodium acetate catalyzed coupling with trimethyl diazophosphonoacetate $\mathbf{2 0}$ gave $\mathbf{4 7} \mathbf{a}, \mathbf{b}-\mathbf{5 0 a}, \mathbf{b}$ in good yields (Scheme 6 and Table 2). The best results were obtained with rhodium acetate $(1 \mathrm{~mol} \%)$ and 1.2 equivalents of the diazophosphonate $\mathbf{2 0}$ in benzene at reflux overnight. Molecular sieves (freshly activated) were added to the mixture to prevent competing insertion of the carbenoid into adventitious traces of water. Notably, use of the lower boiling dichloromethane as solvent does not result in any $\mathrm{O}-\mathrm{H}$ insertion, indicating the increased stability of diazophosphonates compared to diazocarbonyl derivatives, in agreement with Moody's work. ${ }^{30,18 \mathrm{c}}$ In each case, the products of $\mathrm{O}-\mathrm{H}$ insertion were isolated as an essentially equimolar mixture of two epimers readily identified spectroscopically from the characteristic signals in the ${ }^{1} \mathrm{H}$ and ${ }^{13} \mathrm{C}$ NMR spectra for the $\mathrm{CH}$ adjacent to the phosphonate (Scheme 6). On occasion, a slight excess of one epimer can be observed but the ratio (estimated by NMR) was never greater than 60:40, indicating very low diastereoselection in the insertion as had been previously observed. ${ }^{30,18 c}$ Interconversion of the epimers via enolization can be envisaged so the ratio observed may be due to thermodynamic rather than kinetic factors. Interestingly, the NMR signals even at positions quite removed from the epimeric center were frequently quite well distinguished in the two epimers, possibly due to different conformations; for example, in the thymidine series for compound $\mathbf{4 7 b}, \mathrm{C}-6$ appears at $136.0 \mathrm{ppm}$ for the major epimer and at $135.6 \mathrm{ppm}$ for the minor epimer and $\mathrm{C}-1^{\prime}$ appears at $85.0 \mathrm{ppm}$ for the major epimer and at $84.5 \mathrm{ppm}$ for the minor epimer, while for the cytidine series for compound 49a, $\mathrm{C}-1^{\prime}$ appears at 87.2 and $86.8 \mathrm{ppm}$ for the two epimers and $\mathrm{C}-2^{\prime}$ appears at 75.3 and $74.7 \mathrm{ppm}$ for the two epimers, and in the adenosine series for compound 50a, C-1' ${ }^{\prime}$ appears at 85.7 and $85.1 \mathrm{ppm}$ for the two epimers and $\mathrm{C}-2^{\prime}$ appears at

(30) (a) Moody, C. J.; Taylor, R. J. J. Chem. Soc., Perkin Trans. 1 1989, 721. (b) Heslin, J. C.; Moody, C. J. J. Chem. Soc., Perkin Trans. 1 1988, 1471. (c) Davies, M. J.; Moody, C. J.; Taylor, R. J. J. Chem. Soc., Perkin Trans. 1 1991, 1. (d) Moody, C. J. Sie, E.-R. H. B ; Kulagowski, J. J. J Chem. Soc. Perkin Trans. 1 1994, 501. (e) Doyle, M. P.; Yan, M. Tetrahedron Lett. 2002, 43, 5929. (f) Moody, C. J.; Sie, E.-R. H. B.; Kulagowski, J. J. Tetrahedron 1992, 48, 3991.
SCHEME 6. O-H Insertion Reaction

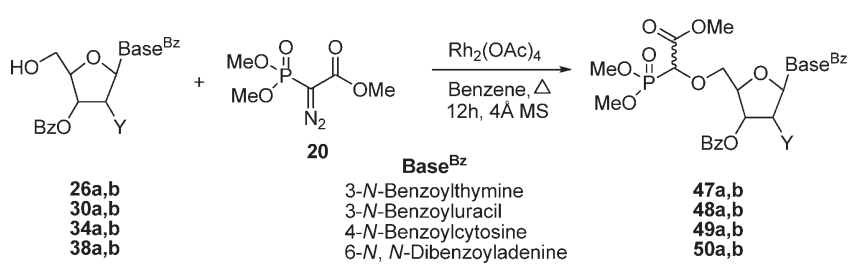

TABLE 2. O-H Insertion Reaction

\begin{tabular}{clccc}
\hline substrate & $\mathrm{Y}$ & conditions $^{a}$ & $\begin{array}{c}\text { product } \\
\text { (overall yield \%) }\end{array}$ & $\begin{array}{c}\text { ratio of } \\
\text { epimers }^{b}\end{array}$ \\
\hline $\mathbf{2 6 a}$ & $\mathrm{OBz}$ & $12 \mathrm{~h}$ & $\mathbf{4 7 a}(61)$ & $1.2: 1$ \\
$\mathbf{2 6 b}$ & $\mathrm{H}$ & $12 \mathrm{~h}$ & $\mathbf{4 7 b}(86)$ & $1.5: 1$ \\
$\mathbf{3 0 a}$ & $\mathrm{OBz}$ & $12 \mathrm{~h}$ & $\mathbf{4 8 a}(72)$ & $1.2: 1$ \\
$\mathbf{3 0 b}$ & $\mathrm{H}$ & $12 \mathrm{~h}$ & $\mathbf{4 8 b}(78)$ & $1: 1$ \\
$\mathbf{3 4 a}$ & $\mathrm{OBz}$ & $12 \mathrm{~h}$ & $\mathbf{4 9 a}(52)$ & $1: 1$ \\
$\mathbf{3 4 b}$ & $\mathrm{H}$ & $12 \mathrm{~h}$ & $\mathbf{4 9 b}(45)$ & $1: 1$ \\
$\mathbf{3 8 a}$ & $\mathrm{OBz}$ & $12 \mathrm{~h}$ & $\mathbf{5 0 a}(66)$ & $1: 1$ \\
$\mathbf{3 8 b}$ & $\mathrm{H}$ & $12 \mathrm{~h}$ & $\mathbf{5 0 b}(28)$ & $1: 1$
\end{tabular}

${ }^{a}$ Reaction conditions: Trimethyl diazophosphonoacetate 20 (1.2 equiv), $\mathrm{Rh}_{2}(\mathrm{OAc})_{4}\left(0.01\right.$ equiv), molecular sieves, benzene, reflux. ${ }^{b}$ After purification by flash chromatography.

75.1 and $74.2 \mathrm{ppm}$ for the two epimers. Phosphorus NMR spectra also prove to be very useful in identifying and quantifying epimeric mixtures.

In the case of guanosine, all the attempts to effect $\mathrm{O}-\mathrm{H}$ insertion reaction using the protected precursors $\mathbf{4 0}$ or $\mathbf{4 3}$ were unsuccessful and in all cases, the starting material was recovered unchanged. This was thought to be due to the insolubility of the selectively protected guanosine precursors 40 and 43 in refluxing benzene or dichloromethane. However, when the more soluble guanosine derivative $\mathbf{4 6}$ was then treated with trimethyl diazophosphonoacetate $\mathbf{2 0}$ and rhodium acetate, rhodium trifluoroacetate or copper(II) acetate, no $\mathrm{O}-\mathrm{H}$ insertion occurred and the starting material 46 was recovered. As catalyst poisoning through complexation to the guanosine base is the most likely cause, use of a stoichiometric amount of copper(II) acetate was attempted, but this led to total degradation of the guanosine derivative $\mathbf{4 6}$.

Thus the key transformation leading to attachment of the phosphono ester moiety proceeds very efficiently with most of the nucleoside precursors. Notably the $\mathrm{O}-\mathrm{H}$ insertions to lead to $\mathbf{4 7 - 5 0}$ are readily conducted on synthetically useful multigram scale without any significant challenges. Each of the phosphonate esters produced are relatively stable compounds which can be stored without degradation.

Deprotection Reactions. With the heavily protected phosphono nucleosides in hand, attention was next focused on efficient deprotection strategies, ideally cleaving multiple protecting groups in single steps. Deprotection of perbenzoylated nucleoside derivatives is generally accomplished with aqueous methanolic ammonia. Treatment of closely related phosphono esters under these conditions resulted in debenzoylation accompanied by conversion of the carboxylic esters to the analogous primary amide. Deprotection involving basic ester hydrolysis using $\mathrm{NaOH} / \mathrm{MeOH}$ was also tried; ${ }^{31}$ while the ester was efficiently hydrolyzed, the subsequent deprotection of phosphonate dialkyl esters using the McKenna procedure with bromotrimethylsilane

(31) Koester, H.; Kulikowskit, K.; Liese, T.; Heikens, W.; Kohli, V. Tetrahedron 1981, 37, 363 . 
SCHEME 7. Deprotection Strategy

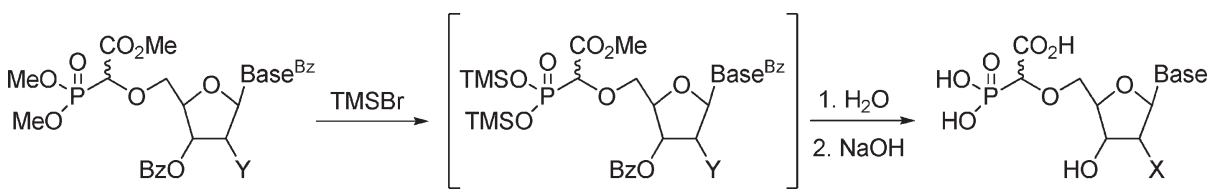

\section{SCHEME 8. Full Deprotection of 47a,b, 48a,b, and 49a}<smiles>CO[13C](=O)c1ccccc1</smiles>

$$
\begin{aligned}
& \text { 1. } \mathrm{TMSBr}, \mathrm{CH}_{2} \mathrm{Cl}_{2} \\
& \text { reflux T} \mathrm{T}^{\circ} \mathrm{C}, 2 \mathrm{~h} \\
& \text { 2. } \mathrm{H}_{2} \mathrm{O}, \mathrm{RT}, 10 \mathrm{~min} \\
& \underset{\text { 3. } \mathrm{NaOH} 1 \mathrm{M}, \mathrm{rt}, 12 \mathrm{~h}}{\longrightarrow} \\
& \text { 4. charcoal column }
\end{aligned}
$$<smiles>[X]C1C([18O])OC(COC(C(=O)O)[PH](O)(O)ON)C1O</smiles>

47a,b 3-N-Benzoylthymine 48a,b 3-N-Benzoyluracil 49a,b 4-N-Benzoylcytosine

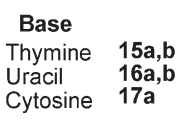

a: $\mathrm{X}=\mathrm{OH}, \mathrm{Y}=\mathrm{OBz} ; \mathbf{b}: \mathrm{X}, \mathrm{Y}=\mathrm{H}$

(TMSBr) followed by the addition of water ${ }^{32}$ led to decomposition of nucleosides.

Accordingly we decided to develop the complete deprotection as a one pot reaction ${ }^{20}$ using first the McKenna procedure with TMSBr to cleave the phosphonate esters, followed by basic hydrolysis of the remaining carboxylate methyl ester and benzoyl groups using a solution of $\mathrm{NaOH}$ (1 M, excess) at room temperature (Scheme 7).

By using this method, full deprotection of the phosphonates was readily achieved in all of the compounds bearing the $2^{\prime}$-hydroxyl group to obtain $15 \mathbf{a}, 16 \mathbf{a}, 17 \mathbf{a}$, and $\mathbf{1 8 a}$. In the case of the adenosine derivative $\mathbf{5 0 a}$, complete deprotection to $\mathbf{1 8 a}$ occurs by using very similar conditions but by heating at reflux temperature during the $\mathrm{NaOH}$ hydrolysis step; when the basic hydrolysis is conducted at room temperature in this case, one benzoyl group remains attached to the 6-amino group of the adenine base to afford the partially deprotected compound $\mathbf{1 8 c}$ (Scheme 9).

However, in the $2^{\prime}$-deoxy series while thymidine and $2^{\prime}$ deoxyuridine derivatives $\mathbf{1 5 b}$ and $\mathbf{1 6} \mathbf{b}$ were readily isolated and characterized, all attempts to obtain the fully deprotected $2^{\prime}$-deoxy cytidine and adenosine derivatives $\mathbf{1 7} \mathbf{b}, \mathbf{1 8 b}$ using TMSBr or $\mathrm{TMSI}^{33}$ failed, leading to complete degradation of the nucleosides (Scheme 8, Scheme 9 and Table 3). These results highlight the increased stability of the 2 -deoxynucleosides with thymine or uracil as bases, with the cytidine and adenosine derivative much more prone to hydrolytic cleavage.

Recovery of the very polar deprotected phosphono nucleosides in pure form from the deprotection steps is not trivial. First the aqueous reaction mixture following the base hydrolysis is acidified to $\mathrm{pH} \approx 1.0-1.5$ using a solution of $\mathrm{HCl}(2 \mathrm{M})$ and extracted several times with dichloromethane to remove benzoic acid. The acidic aqueous residue was then concentrated and adsorbed on a column of activated charcoal for purification. ${ }^{34}$ Elution with water first removed inorganic impurities. Then, elution with a solution of ammonia $(20 \%)$ released the

(32) McKenna, C. E.; Schmidhauser, J. J. Chem. Soc., Chem. Commun. 1979, 739 .

(33) Wu, T.; Froyen, M.; Kempeneer, V.; Pannecouque, C.; Wang, J.; Busson, R.; De Clercq, E.; Herdewijn, P. J. Am. Chem. Soc. 2005, 127, 5056.

(34) Personal communication from Dr. Richard Storer. For one example of charcoal column chromatography see: Tedetti, M.; Kawamura, K.; Charrire, B.; Chevalier, N.; Sempr, R. Anal. Chem. 2006, 78, 6012.

\section{SCHEME 9. Partial and Full Deprotection of 50a}

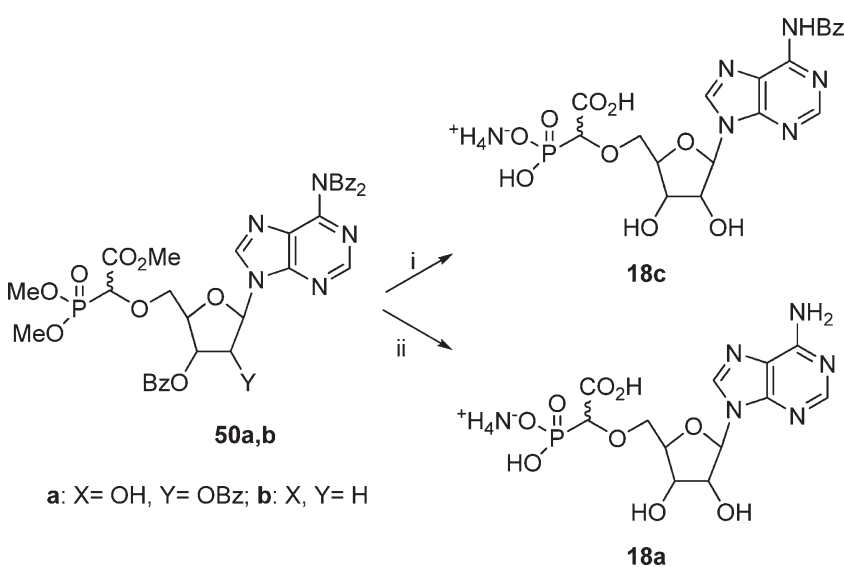

${ }^{a}$ Reagents and conditions: (i) (1) TMSBr (8.0 equiv), reflux, 2 h. (2) $\mathrm{H}_{2} \mathrm{O}, \mathrm{rt}, 10$ min. (3) $\mathrm{NaOH}$ (1 M, excess), room temperature, overnight.

\begin{tabular}{|c|c|c|c|c|c|}
\hline substrate & $\mathrm{Y}$ & $\mathrm{X}$ & conditions $^{a}$ & $\begin{array}{c}\text { product } \\
(\text { overall yield } \%)^{b}\end{array}$ & $\begin{array}{c}\text { ratio of } \\
\text { epimers }\end{array}$ \\
\hline $47 a$ & $\mathrm{OBz}$ & $\mathrm{OH}$ & A & 15a (82) & $1.2: 1$ \\
\hline $47 \mathrm{~b}$ & $\mathrm{H}$ & $\mathrm{H}$ & A & 15b $(57)$ & $1.5: 1$ \\
\hline $48 a$ & $\mathrm{OBz}$ & $\mathrm{OH}$ & A & $16 \mathbf{a}(56)$ & $1.2: 1$ \\
\hline $48 \mathrm{~b}$ & $\mathrm{H}$ & $\mathrm{H}$ & A & 16b (61) & 1:1 \\
\hline $49 a$ & $\mathrm{OBz}$ & $\mathrm{OH}$ & B & 17a (57) & $1: 1$ \\
\hline $49 \mathrm{~b}$ & $\mathrm{H}$ & $\mathrm{H}$ & B & - & - \\
\hline $50 \mathrm{a}$ & $\mathrm{OBz}$ & $\mathrm{OH}$ & $\mathrm{C}$ & 18a (61) & $1: 1$ \\
\hline $50 \mathrm{~b}$ & $\mathrm{H}$ & $\mathrm{H}$ & $\mathrm{C}$ & - & - \\
\hline
\end{tabular}
(ii) (1) $\mathrm{TMSBr}$ (8.0 equiv), reflux, 2 h. (2) $\mathrm{H}_{2} \mathrm{O}$, rt, 10 min. (3) $\mathrm{NaOH}$ (1 M, excess), reflux temperature, overnight.

TABLE 3. Total deprotection

${ }^{a}$ Reaction conditions: (Method A) 1. TMSBr (4.0 equiv), reflux, 2 h. 2. $\mathrm{H}_{2} \mathrm{O}, \mathrm{rt}, 10$ min. 3. $\mathrm{NaOH}$ (1 M, excess), rt, overnight. (Method B) 1. TMSBr (8.0 equiv), reflux, 2 h. $2 . \mathrm{H}_{2} \mathrm{O}$, rt, 10 min. 3 . $\mathrm{NaOH}$ ( $1 \mathrm{M}$, excess), rt, overnight. (Method C) 1. TMSBr (8.0 equiv), reflux, 2 h. 2. $\mathrm{H}_{2} \mathrm{O}$, rt, 10 min. 3. $\mathrm{NaOH}\left(1 \mathrm{M}\right.$, excess), reflux, overnight. ${ }^{b}$ After purification by charcoal column.

desired products as their ammonium salts $\mathbf{1 5 a}, \mathbf{b}, \mathbf{1 6} \mathbf{a}, \mathbf{b}, \mathbf{1 7} \mathbf{a}$, and 18a. In the case of the partially deprotected phosphonate 18c, a mixture of ethanol $/ \mathrm{H}_{2} \mathrm{O} / \mathrm{NH}_{4} \mathrm{OH}(10: 10: 3)$ was needed to elute the product as no organic compound was released by elution with a solution of ammonia (20\%). The purification is followed by the presence of UV-visible spots on TLC. The fractions containing the phosphonates were lyophilized to give the desired phosphonates 15a,b, 16a,b, 17a, and 18a as their ammonium salt. In the case of cytidine $\mathbf{1 7} \mathbf{a}$ and adenosine $\mathbf{1 8 a}$, it is essential to acidify accurately to $\mathrm{pH} 2.5$ for optimal purification. At $\mathrm{pH} \approx$ $1.0-2.0$, or at $\mathrm{pH}>3.0$, some compounds are released from the charcoal column with the first fractions of water along with the inorganic impurities. Use of activated charcoal as an absorbent allowed elution of the very polar compounds $\mathbf{1 5 a}, \mathbf{b}, \mathbf{1 6}, \mathbf{a}, \mathbf{b}, \mathbf{1 7} \mathbf{a}$, and 18a with good recovery and high purity.

Compounds 15a,b, 16a,b, 17a, and 18a,c were isolated in stable form as ammonium salts after purification by charcoal 


\section{SCHEME 10. Synthesis of AZT Derivatives ${ }^{a}$}
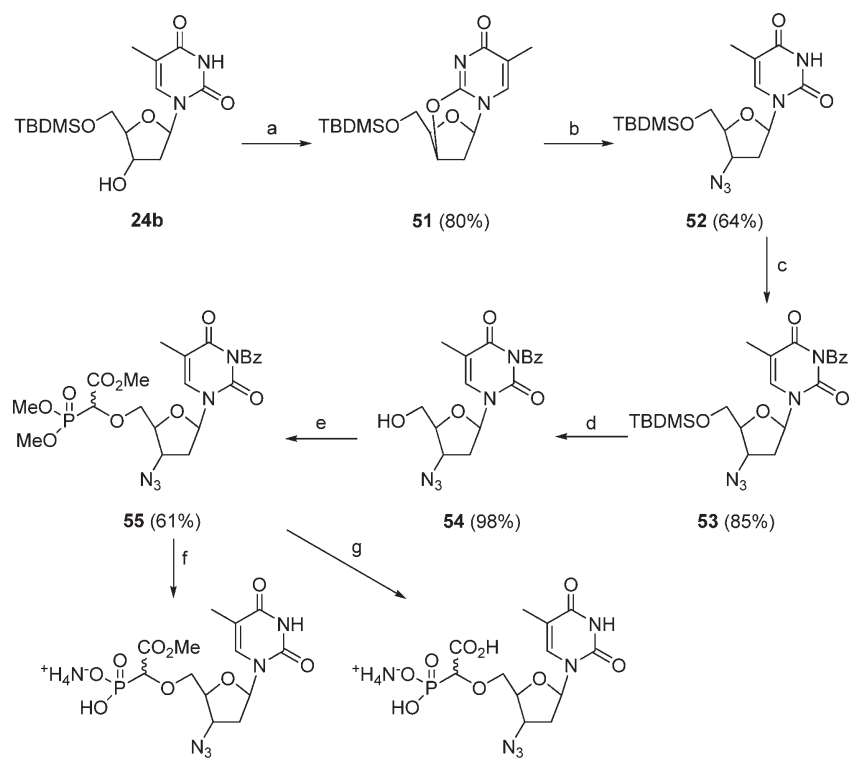

$54(98 \%)$

$53(85 \%)$

$56(60 \%)$

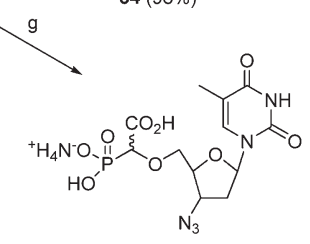

$57(69 \%)$

\begin{abstract}
${ }^{a}$ Reagents and conditions: (a) DIAD, $\mathrm{PPh}_{3}, \mathrm{DMF}, \mathrm{rt}, 2$ h. (b) $\mathrm{NaN}_{3}$, DMF, rt, overnight. (c) BzCl, DMAP, $\mathrm{NEt}_{3}, \mathrm{CH}_{2} \mathrm{Cl}_{2}, \mathrm{rt}$, overnight. (d) TFA $/ \mathrm{H}_{2} \mathrm{O} / \mathrm{THF}$ (1:1:4), rt, 3 h. (e) 20 (1.1 equiv), $\mathrm{Rh}_{2}(\mathrm{OAc})_{4}$, benzene, reflux temperature, overnight. (f) (1) $\mathrm{TMSBr}$ (5.0 equiv), $\mathrm{CH}_{2} \mathrm{Cl}_{2}$, reflux temperature, $2 \mathrm{~h}$; (2) $\mathrm{H}_{2} \mathrm{O}$, rt, 10 min; (3) $\mathrm{NaOH}$ (1 M, 1.4 equiv). (g) 1) TMSBr (5.0 equiv), $\mathrm{CH}_{2} \mathrm{Cl}_{2}$, reflux temperature, $2 \mathrm{~h}$; (2) $\mathrm{H}_{2} \mathrm{O}$, rt, $10 \mathrm{~min}$; (3) $\mathrm{NaOH}(1 \mathrm{M}$, excess).
\end{abstract}

column chromatography and could be effectively characterized by ${ }^{1} \mathrm{H},{ }^{13} \mathrm{C},{ }^{31} \mathrm{P}$ NMR, and mass spectrometry. In each case, a pair of epimers is seen. After lyophilization, these salts are isolated as fine white powders that can be readily stored for extended periods without noticeable decomposition.

Interestingly, in some of the deprotected phosphonic acid derivatives the signals for the CHP carbon were not detected in the ${ }^{13} \mathrm{C}$ NMR; it is believed that this is due to deuterium exchange in $\mathrm{D}_{2} \mathrm{O}$ used as NMR solvent.

Strategy Applied to AZT. Use of our neutral transition metal catalyzed transformation to generate the AZT derivative 57 bearing the phosphono acetic acid group at $5^{\prime}$ was next attempted. At the outset of the work the stability of the azide substituent to the carbenoid intermediates and the rhodium catalyst was uncertain. Interestingly, a phosphonomethoxy AZT analog has been recently reported in literature. ${ }^{5 \mathrm{~d}}$ However, in this case the introduction of the phosphonate moiety is effected in an acidic glycosylation.

The phosphono AZT analog was prepared from thymidine according to Scheme 10. In the first step, $5^{\prime}$-O-tert-butyldimethylsilylthymidine $\mathbf{2 4 b}$ was treated with diisopropyl azodicarboxylate (DIAD) and triphenylphosphine $\left(\mathrm{PPh}_{3}\right)$ in $\mathrm{DMF}$ to give $2^{\prime}, 3^{\prime}$-anhydro-5'-O-tert-butyldimethylsilylthymidine $\mathbf{5 1}$ via an intramolecular Mitsunobu reaction. ${ }^{35}$ Introduction of the azido group to the $3^{\prime}$-position was then carried out by ring-opening with sodium azide in DMF to afford the previously reported $5^{\prime}-O$-TBDMS protected AZT derivative

(35) (a) Czernecki, S.; Valery, J. M. J. Chem. Soc., Chem. Commun. 1990, 801. (b) Hiebl, J.; Zbiral, E.; Balzarini, J.; De Clercq, E. J. Med. Chem. 1990, 33,845 .
52. ${ }^{35 b}$ Insertion of the azide group was confirmed by ${ }^{1} \mathrm{H}$, IR (absorbance at $2105 \mathrm{~cm}^{-1}$ ) and mass spectrometry. The $N-1$ amine was subsequently protected by benzoylation with benzoyl chloride, 4- $N, N$-(dimethylamino)pyridine (DMAP), triethylamine (to prevent any $\mathrm{N}-\mathrm{H}$ insertion on exposure to the diazophosphonate 20), followed by desilylation using a mixture of TFA $/ \mathrm{H}_{2} \mathrm{O} / \mathrm{THF}(1: 1: 4)$ to afford $3^{\prime}$-azido-3'-deoxy, 3- $\mathrm{N}$-benzoylthymidine 54 suitably protected for the $\mathrm{O}-\mathrm{H}$ insertion reaction. The selectively protected AZT derviatives 53 and 54 are novel and are likely to have other synthetic applications in generation of AZT derivatives.

Despite concerns regarding the stability of the azido group in the carbenoid insertion step, the key reaction proceeded very well and afforded the desired product $\mathbf{5 5}$ with a good yield of $60 \%$ without any degradation of the azide group. This highlights the scope of the novel methodology and its compatibility with the relatively reactive azido substituent.

On the basis of the earlier work, deprotection was effected in a one pot process using bromotrimethylsilane (TMSBr) to cleave the phosphonate esters followed by basic (1 M NaOH, excess) hydrolysis of the remaining methyl carboxylate ester and $\mathrm{N}$ benzoyl group at room temperature; purification by charcoal column by elution with a solution of ammonia (20\%) afforded the AZT analogue $\mathbf{5 7}$ as its ammonium salt in an impressive overall yield of $69 \%$ for the multiple deprotection processes.

Interestingly by using just $1.5 \mathrm{~mol}$ equiv of $\mathrm{NaOH}$ in the deprotection sequence, the partially deprotected methyl ester 56 was obtained cleanly in good yield after charcoal column. As in the same case of the partially deprotected compound 18c, a mixture of ethanol $/ \mathrm{H}_{2} \mathrm{O} / \mathrm{NH}_{4} \mathrm{OH}(10: 10: 3)$ was needed to elute the product as the ammonium salt. This interesting observation offers potential for the synthesis of prodrugs bearing lipophilic chains at the ester moiety.

Di- and Triphosphorylation Steps. As compounds 56 and 57 were found to be active against HIV-1 and -2 albeit at low levels (Table 5), phosphorylation of these AZT derivatives was required for enzymatic testing to establish if they display RT inhibition. At the outset of the project the phosphononucleosides bearing an $\alpha$-carboxylic acid moiety were envisaged to act as potential diphosphate mimics, with the carboxylic acid mimicking one phosphate unit. Therefore, the monophosphorylated phosphononucleosides $\mathbf{5 8}$ and $\mathbf{5 9}$ were key targets for synthesis with both the free carboxylic acid and the methyl ester at the $\alpha$-position, for evaluation as AZT triphosphate mimics as illustrated in Figure 9. Furthermore, the analogous diphosphorylated phosphononucleosides $\mathbf{6 0}$ and $\mathbf{6 1}$ were also identified as key synthetic targets for exploration; involvement of the carboxylic acid group may not in fact occur, and therefore 60 and 61 would be essential to be evaluated as potential AZT triphosphate mimics.

Thus attachment of phosphate and pyrophosphate units to the novel phosphononucleoside of AZT was next undertaken as summarized in Scheme 11.

Two principal strategies were explored to selectively phosphorylate the $5^{\prime}$-phosphonate 57 bearing the free $\alpha$ carboxylic acid function: the first was to attempt selective phosphorylation at the phosphonate in the presence of the carboxylic acid, while the second involved initial phosphorylation of the partially deprotected methyl ester phosphonate 56 followed by deprotection of the methyl ester without cleavage of the phosphate bond. Both strategies had associated challenges at the outset-selective phosphorylation at 


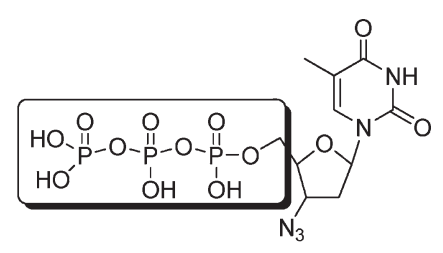

AZT-triphosphate
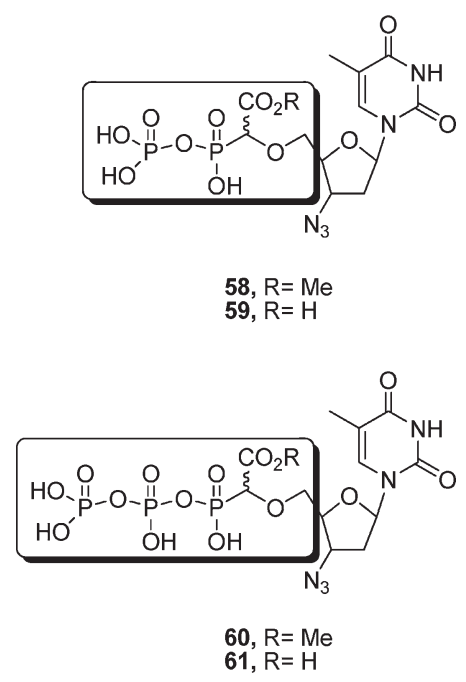

FIGURE 9. Monophosphorylated phosphononucleosides $\mathbf{5 8}$ and 59 diphosphorylated phosphononucleosides $\mathbf{6 0}$ and $\mathbf{6 1}$ as AZT triphosphate mimics.

a phosphonic acid moiety in the presence of an adjacent carboxylic acid group has not been previously described, to the best of our knowledge, and indeed it is difficult to envisage activation of the phosphonic acid moiety without interference by the carboxylic acid. Use of the ester avoids the challenges associated with competing reaction at the carboxylic acid moiety, but in this case it is necessary to effect ester hydrolysis without cleavage of the newly attached phosphate groups. In the event, the second strategy proved very successful and led to both the phosphate and pyrophosphate derivatives 58-61 with both the ester and carboxylic acid groups.

Initial attempts focused on direct phosphorylation of the $\alpha$-carboxyl phosphonate $\mathbf{5 7}$ using the procedure described by Hoard et al. ${ }^{36}$ Compound $\mathbf{5 7}$ was first converted to its triethylammonium salt in order to confer solubility in organic solvents. Activation of this nucleoside $5^{\prime}$-phosphonate salt with 1,1-carbonyldiimidazole (CDI) was undertaken, then the excess of CDI was decomposed with methanol, and then condensation of the $5^{\prime}$-phosphoroimidazolidate intermediate with tributylammonium phosphate was attempted. All attempts at this direct phosphorylation led to complex mixtures of products. Mass spectrometry showed a molecular peak at $\mathrm{m} / z 564.0$ suggesting phosphorylation on both the carboxylic acid and the phosphonate. Clearly selective activation of phosphonic acid for phosphorylation in the presence of the free carboxylic moiety is not feasible.

(36) (a) Hoard, D. E.; Ott, D. G. J. Am. Chem Soc. 1965, 87, 1785. (b) Crauste, C.; Perigaud, C.; Peyrottes, S. J. Org. Chem. 2009, 74, 9165. (c) Freeman, G. A.; Rideout, J. L.; Miller, W. H.; Reardon, J. E. J. Med. Chem. 1992, 35, 3192 .

\section{SCHEME 11. Mono and diphosphorylation reactions. ${ }^{a}$}

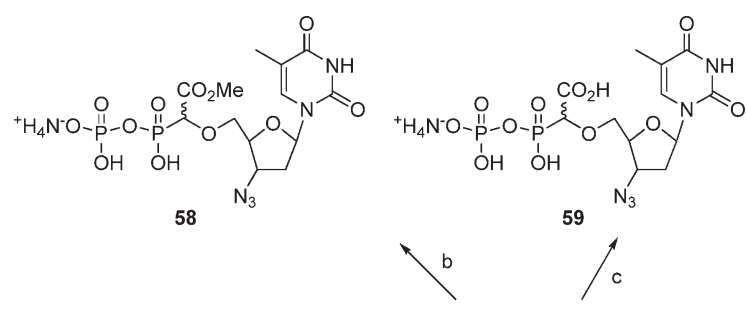

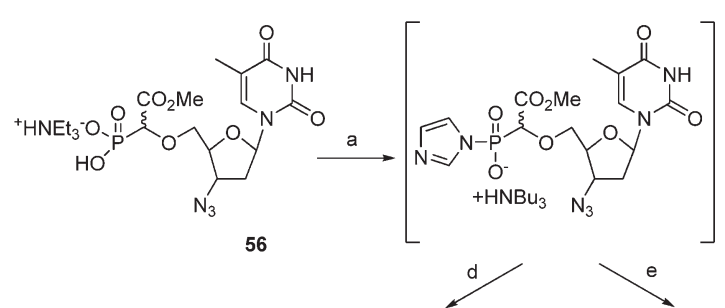

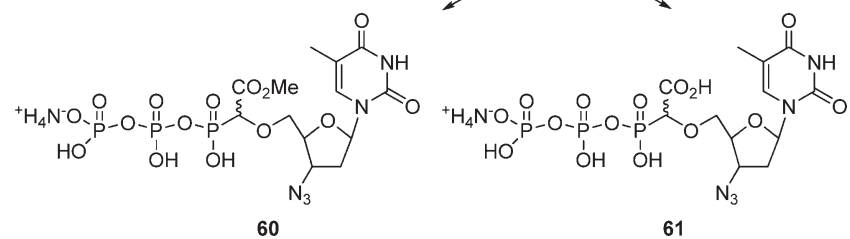

${ }^{a}$ Reagents and conditions: (a) (1) CDI (6 equiv), DMF, rt, 5 h; (2) $\mathrm{MeOH}$ (12 equiv), rt, $30 \mathrm{~min}$. (b) (1) tri- $n$-butylammonium phosphate (1 M solution in DMF, 6 equiv), rt, overnight; (2) $\mathrm{H}_{2} \mathrm{O}, \mathrm{rt}, 10 \mathrm{~min}$; (3) DEAE A-25 (ammonium bicarbonate solution). (c) (1) tri- $n$-butylammonium phosphate (1 M solution in DMF, 6 equiv), rt, overnight; (2) $\mathrm{NaOH}$ (1 M, excess), rt, $6 \mathrm{~h}$; (3) DEAE A-25 (ammonium bicarbonate solution). (d) (1) tri- $n$-butylammonium pyrophosphate (6 equiv), rt, overnight; (2) $\mathrm{H}_{2} \mathrm{O}, \mathrm{rt}, 10 \mathrm{~min}$; (3) DEAE A-25 (ammonium bicarbonate solution). (e) (1) tri- $n$-butylammonium pyrophosphate (6 equiv), rt, overnight; (2) NaOH (1 M, excess), rt, 6 h; (3) DEAE A-25 (ammonium bicarbonate solution).

TABLE 4. Mono- and Diphosphorylation Reactions

\begin{tabular}{cccccc}
\hline compounds & $\mathbf{5 8}$ & $\mathbf{5 9}$ & $\mathbf{6 0}$ & $\mathbf{6 1}$ \\
\hline procedure & $\mathrm{B}$ & $\mathrm{c}$ & $\mathrm{d}$ & $\mathrm{e}$ \\
yield $^{a}(\%)$ & 71 & 64 & 58 & 84 \\
${ }^{31} \mathrm{P} \mathrm{NMR}$ & $\alpha$ & $\sim-7.7$ & $\sim-10.2$ & $\sim-8.2$ & $\sim-8.1$ \\
& $\beta$ & $\sim-0.2$ & $\sim-2.9$ & $\sim-22.2$ & $\sim-22.0$ \\
& $\gamma$ & - & - & $\sim-8.2$ & $\sim-8.5$
\end{tabular}

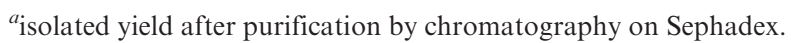

Accordingly we next explored the same procedure described by Hoard et al. ${ }^{36}$ on the partially deprotected methyl ester phosphonate $\mathbf{5 6}$ to avoid competing activation of the carboxylic acid (Scheme 11). Compound $\mathbf{5 6}$ was first converted to the triethylammonium salt, again to effect solubility in the reaction medium, then transformed to the imidazolidate intermediate in the presence of an excess of CDI (6 equiv). Unreacted CDI was decomposed with methanol and then an excess of inorganic phosphate (6 equiv) was added. We first carried out the reaction using the readily available disodium hydrogen phosphate, and while the reaction occurred the product isolated was not very clean probably due to the poor solubility of disodium hydrogen phosphate in DMF. Therefore a solution of tributylammonium phosphate $(1 \mathrm{M} \text { in } \mathrm{DMF})^{37}$ was prepared to confer solubility to the inorganic phosphate in organic solvents. After addition of the solution of tributylammonium phosphate in DMF (1M, 6 equiv) to the activated imidazolidate intermediate, the phosphorylation was completed overnight at room temperature in

(37) Kore, A. R.; Parmar, G. Synth. Commun. 2006, 36, 3393. 
TABLE 5. Inhibitory Activity of AZT Derivatives against HIV and MSV in Cell Culture and HIV-1 RT in a Cell-Free Enzyme Assay

\begin{tabular}{|c|c|c|c|c|c|c|}
\hline & \multicolumn{4}{|c|}{$\mathrm{EC}_{50}{ }^{a}(\mu \mathrm{g} / \mathrm{mL})$} & \multirow{3}{*}{$\begin{array}{c}\mathrm{CC}_{50}^{b}(\mu \mathrm{g} / \mathrm{mL}) \\
(\mathrm{CEM} / 0)\end{array}$} & \multirow{3}{*}{$\begin{array}{c}\mathrm{IC}_{50}{ }^{c}(\mu \mathrm{g} / \mathrm{mL}) \\
\text { HIV-1 RT (poly rA/dT) }\end{array}$} \\
\hline & \multicolumn{2}{|c|}{ CEM/0 } & \multirow{2}{*}{$\begin{array}{c}\text { CEM/TK }{ }^{-} \\
\text {HIV-2 (ROD) }\end{array}$} & \multirow{2}{*}{$\begin{array}{c}\mathrm{C} 3 \mathrm{H} / 3 \mathrm{~T} 3 \\
\mathrm{MSV}\end{array}$} & & \\
\hline & HIV-1 (III $\left.{ }_{B}\right)$ & HIV-2 (ROD) & & & & \\
\hline 56 & $10 \pm 2.7$ & $7.6 \pm 7.7$ & $>100$ & $8.8 \pm 0.9$ & $>200$ & $>100$ \\
\hline 57 & $5.6 \pm 2.2$ & $2.6 \pm 2.0$ & $>100$ & $7.7 \pm 1.4$ & $>200$ & $89 \pm 15$ \\
\hline 58 & $56 \pm 63$ & $12 \pm 0.71$ & $>100$ & $14 \pm 1$ & $>100$ & $141 \pm 34$ \\
\hline 59 & $35 \pm 30$ & $13 \pm 1.4$ & $>100$ & $51 \pm 3$ & $>100$ & $109 \pm 60$ \\
\hline 60 & $>100$ & $>100$ & $>100$ & $\geq 100$ & $>100$ & $63 \pm 26$ \\
\hline 61 & $\geq 100$ & $\geq 100$ & $>100$ & $>20$ & $>100$ & $46 \pm 28$ \\
\hline AZT & 0.0096 & 0.0088 & $>67$ & $0.010 \pm 0.006$ & $>67$ & $0.008^{d} \pm 0.0040$ \\
\hline
\end{tabular}

${ }^{a}$ Fifty percent effective concentration, or compound concentration required to inhibit HIV-induced cytopathicity in CEM cell cultures or MSVinduced transformation of $\mathrm{C} 3 \mathrm{H} / 3 \mathrm{~T} 3$ cell culture. ${ }^{b}$ Fifty percent cytostatic concentration, or compound concentration required to inhibit $\mathrm{CEM}$ cell proliferation by $50 \%$. ${ }^{c}$ Fifty percent inhibitory concentration, or compound concentration required to inhibit HIV-1 RT-catalyzed incorporation of $\left[{ }^{3} \mathrm{H}\right] \mathrm{dTTP}$ in poly rA.oligo dT template. ${ }^{d}$ AZT-TP used as the competing substrate.

this instance leading to a clean reaction product, the monophosphorylated phosphononucleoside $\mathbf{5 8}$ as a fine white solid in $71 \%$ yield.

Extension of this initial successful phosphorylation to use of commercially available tributylammonium pyrophosphate led to the analogous diphosphorylated phosponate 60, again as a fine white solid in 58\% yield, in an equally efficient process with attachment of two phosphate units in this instance. Thus mono- and diphosphorylation is readily effected in the presence of the ester moiety but not with the free carboxylic acid group. The next challenge was to develop conditions for selective hydrolysis of the methyl ester. In the event this was readily achieved by very similar reaction conditions to those used for the synthesis of $\mathbf{5 8}$ and $\mathbf{6 0}$, but with addition of an excess of $1 \mathrm{M}$ $\mathrm{NaOH}$ following the phosphorylation step. Stirring overnight prior to product isolation, resulted in efficient ester hydrolysis leading to both mono- and diphosphorylated phosphononucleoside analogues $\mathbf{5 9}$ and $\mathbf{6 1}$, this time with the free carboxylic acid groups at the $\alpha$-position, as fine white solids in 64 and $84 \%$ yield respectively.

All four phosphorylated phosphononucleosides were readily purified by ion exchange chromatography on DEAE A-25 using ammonium bicarbonate solution as eluent $(50 \mathrm{mM}$ to $500 \mathrm{mM}$ ) followed by lyophilization to obtain the products as fine white solids as the ammonium salts. These were readily characterized by ${ }^{1} \mathrm{H},{ }^{13} \mathrm{C}$ and ${ }^{31} \mathrm{P}$ NMR spectroscopy. As before, each of the compounds was obtained as a mixture of two epimers with a slight excess of one in each case. In the ${ }^{1} \mathrm{H}$ and ${ }^{13} \mathrm{C}$ NMR the signals for the $\mathrm{PCH}$ were not seen, presumably due to rapid exchange with $\mathrm{D}_{2} \mathrm{O}$ at this labile center.

The characteristic ${ }^{31} \mathrm{P}$ NMR spectra are summarized in Table 4 and are in agreement with data published for related phosphorylated nucleosides, ${ }^{38}$ confirming the successful attachment of one or two phosphate units to the novel AZT phosphononucleosides to give 58-61.

Biological Evaluation. Compounds 15a, 15b, 16a, 16b, 17a and 18a have been evaluated against a broad variety of DNA and RNA viruses, as well as against HIV-1 and HIV-2 replication in CEM cell cultures and MSV-induced transformation of $\mathrm{C} 3 \mathrm{H} / 3 \mathrm{~T} 3$ cell cultures and found to be inactive at $100 \mu \mathrm{g} / \mathrm{mL}$. Neither were the compounds cytotoxic to HEL, Vero, HeLa, $\mathrm{CEM}$ and $\mathrm{C} 3 \mathrm{H} / 3 \mathrm{~T} 3$ cells at this concentration. In contrast, the phosphono AZT derivatives 56 and 57, bearing an $\alpha$-carboxylic acid moiety, (potential AZT diphosphate mimic), and the

(38) Lee, S. E.; Elphick, L. M.; Anderson, A. A.; Bonnac, L.; Child, E. S.; Mann, D. J.; Gouverneur, V. Bioorg. Med. Chem. Lett. 2009, 19, 3804. monophosphorylated phosphono AZT nucleosides $\mathbf{5 8}$ and $\mathbf{5 9}$ (potentially acting as AZT triphosphate mimics) were endowed with measurable anti-HIV-1 and - HIV-2 activity (Table 5). The $\mathrm{EC}_{50}$ values ranked between 2.6 and $56 \mu \mathrm{g} / \mathrm{mL}$, that is at compound concentrations that were higher than 300- to 6,000 fold the AZT concentration required to afford a similar antiviral effect. Similar observations were recorded for inhibition of MSV-induced transformation of $\mathrm{C} 3 \mathrm{H} / 3 \mathrm{~T} 3$ cell cultures. The 60 and 61 derivatives were virtually devoid of antiviral potential in these cell cultures. None of the AZT derivatives were inhibitory to HIV-2 in thymidine kinase-deficient CEM TK ${ }^{-}$ cell cultures (Table 5). Also, when examined directly as potential inhibitors of HIV-1 RT-catalyzed incorporation of $\left[{ }^{3} \mathrm{H}\right] \mathrm{dTTP}$ in a poly rA/oligo dT template/primer, the compounds showed poor if any inhibitory activity. The concentrations to affect $50 \%$ of the RT reaction were more than 3 orders of magnitude higher than those required for AZT-TP. None of the compounds inhibited $\left[{ }^{3} \mathrm{H}\right] \mathrm{dGTP}$ incorporation into poly $\mathrm{rC} /$ oligo $\mathrm{dG}$ at $200 \mu \mathrm{g} / \mathrm{mL}$ (not shown). It is intriguing to observe that the compounds completely lost anti-HIV-2 activity in CEM/TK ${ }^{-}$ cell cultures that were deficient for thymidine kinase, the enzyme required to phosphorylate (activate) AZT. These data may suggest that TK activity is required for antiviral activity of the test compounds 56-59. This may mean that the $\alpha$-carboxylic acid moiety is not entirely stably linked to the AZT nucleoside and that compounds 56-59 are slowly releasing free AZT (accounting for the observed antiviral activity). Alternatively, traces of free AZT could be present in the samples. Since contaminating AZT amounts as low as $0.1 \%$ in the product samples can explain the antiviral data, such contamination cannot be excluded as being responsible for the observed antiviral activity. It was possible to detect AZT at very low levels in one of the samples, but not the others. In any case, it can be concluded that the compounds 56-61 showed poor, if any, anti-HIV activity in cell culture, and do not display a significant inhibition of the HIV-1-encoded reverse transcriptase.

\section{Conclusions}

Rhodium acetate mediated $\mathrm{O}-\mathrm{H}$ insertions with trimethyl diazophosphonoacetate $\mathbf{2 0}$ at the $5^{\prime}-\mathrm{OH}$ proceed effectively under neutral mild conditions with suitably protected nucleosides. The methodology is compatible with thymine, uracil, adenine and cytosine, but has not been achieved to date in the presence of guanine. Both the 2 -deoxy series and nucleosides bearing a $2^{\prime}-\mathrm{OH}$ group can be effectively functionalized in this way. Complete deprotection is effected in a one pot process by 
initial cleavage of the phosphono esters with TMSBr followed by basic hydrolysis to remove all remaining protection. While the analogues of uridine, adenosine, cytosine, 5-methyl uridine and 2 -deoxyuridine, thymidine, were readily isolated in deprotected form as their ammonium salts, the more labile 2 '-deoxyadenosine and cytidine derivatives proved unstable to the deprotection conditions. Extension of this methodology to AZT to illustrate the compatibility with the relatively reactive azido group was successful. The novel phosphononucleosides bearing an $\alpha$-carboxylic acid group are envisaged as potential diphosphate mimics. Conversion of the AZT phosphononucleoside 57 to the analogous mono- and diphosphate derivatives has been successfully obtained with both methyl ester and free carboxylic acid groups adjacent to the phosphonate moiety for evaluaton as AZT triphosphate mimics. Unfortunately, the compounds were at least 3 orders of magnitude less inhibitory than AZT to HIV-infected cells and HIV RT-catalyzed DNA polymerase activity.

\section{Experimental Section}

All solvents were distilled prior to use as follows: dichloromethane was distilled from phosphorus pentoxide and ethyl acetate was distilled from potassium carbonate. Organic phases were dried using anhydrous magnesium sulfate. All commercial reagents were used without further purification.

${ }^{1} \mathrm{H}$ and ${ }^{13} \mathrm{C}$ NMR spectra were recorded at room temperature $\left(\sim 20^{\circ} \mathrm{C}\right)$ in deuterated chloroform $\left(\mathrm{CDCl}_{3}\right)$ unless otherwise stated using tetramethylsilane (TMS) as an internal standard on a $300 \mathrm{MHz}, 400 \mathrm{MHz}$ or in some cases $600 \mathrm{MHz}$ NMR spectrometer. ${ }^{1} \mathrm{H}-{ }^{1} \mathrm{H}$ and ${ }^{1} \mathrm{H}-{ }^{13} \mathrm{C}$ correlations were used to confirm the NMR peak assignments. ${ }^{31} \mathrm{P}$ chemical shifts are reported in ppm relative to $\mathrm{H}_{3} \mathrm{PO}_{4}$ (external standard). Chemical shifts were expressed in parts per million (ppm) and coupling constants $(J)$ in hertz $(\mathrm{Hz})$.

Melting points were carried out on a capillary melting point apparatus. Mass spectra were obtained at $70 \mathrm{eV}$. Infrared spectra were recorded as potassium bromide $(\mathrm{KBr})$ discs for solids or thin films on sodium chloride plates for oils. Optical rotation was measured using a Polarimeter. Reversed phase analytical HPLC for deprotected phosphonate compounds was performed using a C18 $1.8 \mu \mathrm{m}$ column $(50 \mathrm{~mm} \times 4.6 \mathrm{~mm})$, (solvent $\mathrm{A}=0.1 \% \mathrm{TFA}$ in water; solvent $\mathrm{B}=0.1 \% \mathrm{TFA}$ in acetonitrile). Conditions were as follows for compounds $\mathbf{1 5} \mathbf{a}-\mathbf{b}$, 16a-b, 17a, 18a: $1 \%$ solvent $B$ in solvent $A$ over $9 \mathrm{~min}$, conditions were as follows for compounds 56 and $\mathbf{5 7 :} 8 \%$ solvent $\mathrm{B}$ in solvent A over 9 min, monitored by UV absorption at 254 $\mathrm{nm}$. All final compounds were found to have $\geq 95 \%$ purity unless otherwise specified.

Thin layer chromatography (TLC) was carried out on precoated silica gel plates (60 PF254). Column chromatography was performed using silica gel 60 . Visualization was achieved by UV (254 nm) light detection.

p-Toluenesulfonyl azide was prepared from p-toluenesulfonyl chloride and sodium azide. ${ }^{39}$ Trimethyl diazophosphonoacetate was prepared using the described procedure in literature ${ }^{22}$ using potassium carbonate as a base.

Purification by Charcoal Chromatography Column. ${ }^{34}$ Purification of phosphonic acids was done on a column of activated carbon G-60 made from a sintered glass funnel, packed with activated charcoal, placed on a Buchner flask connected to a vacuum source. First a thin layer of Celite $(1-2 \mathrm{~mm})$ was put on the funnel with fritted disk and then the charcoal (mass of about 10-20 times the mass of the sample to purify) was packed on top. Vacuum

(39) Dermer, O. C.; Edmison, M. T. J. Am. Chem. Soc. 1955, 77, 70. is used to elute the column. Before use, the column was first washed with methanol (about 4 times the height of the charcoal pad) then with water (about 5 to 8 times the height of the charcoal pad). The acidic residue was dissolved in water $($ at $\mathrm{pH} \approx 1-2.5)$ and adsorbed on the charcoal. The column was eluted with water to remove inorganic impurities, then eluted with aqueous ammonia $(20 \%)$ to release the desired compound as the ammonium salt. The purification can be followed by TLC to check for presence of nucleosides using a UV lamp. The fractions containing the desired phosphonic acid were lyophilized in vacuo to afford the desired compound as its ammonium salt.

Procedure A. 5'-O-tert-Butyldimethylsilyl Protection. 5'-Otert-Butyldimethylsilylthymidine $(\mathbf{2 4 b}){ }^{40}$ tert-Butyldimethylsilyl chloride $(0.75 \mathrm{~g}, 4.95 \mathrm{mmol})$ was added to a solution of thymidine 23b ( $1.00 \mathrm{~g}, 4.13 \mathrm{mmol})$ and imidazole $(0.55 \mathrm{~g}, 9.58 \mathrm{mmol})$ in DMF $(15 \mathrm{~mL})$. The resulting mixture was stirred overnight at room temperature, then poured into crushed ice/water $(20 \mathrm{~mL})$. The white precipitate was collected by filtration and dried in vacuo affording the title product $24 \mathrm{~b}(1.36 \mathrm{~g}, 92 \%)$. mp: $185-186{ }^{\circ} \mathrm{C}$ (lit. ${ }^{37 \mathrm{a}}$ : $192-194{ }^{\circ} \mathrm{C}$ ). Spectroscopic data were in accordance with the literature. $\delta_{\mathrm{H}}\left(300 \mathrm{MHz} ; \mathrm{CDCl}_{3}\right) 8.73(\mathrm{br} \mathrm{s}, 1 \mathrm{H}, \mathrm{NH}), 7.52$ (finely split s, $1 \mathrm{H}, \mathrm{H}-6), 6.37$ (dd, $1 \mathrm{H}, J=8.1,5.6 \mathrm{~Hz}, \mathrm{H}-1^{\prime}$ ), 4.474.45 (sym m, 1H, H-3'), 4.06-4.03 (X part of ABX system, m, 1H, $\mathrm{H}-4^{\prime}$ ), 3.90 (A part of ABX system, $1 \mathrm{H}, J=11.4,2.7 \mathrm{~Hz}$, one of $\mathrm{H}-5^{\prime}$ ), 3.83 (B part of ABX system, $1 \mathrm{H}, J=11.4,2.7 \mathrm{~Hz}$, one of $\left.\mathrm{H}-5^{\prime}\right), 2.50$ (br s, OH), 2.35 (ddd, $1 \mathrm{H}, J=13.5,5.6,2.5 \mathrm{~Hz}$, one of the $\left.\mathrm{H}-2^{\prime}\right), 2.10\left(\mathrm{ddd}, 1 \mathrm{H}, J=13.5,8.1,6.0 \mathrm{~Hz}\right.$, one of the $\left.\mathrm{H}-2^{\prime}\right), 1.92$ (s, 3H, CH $\left.\mathrm{CH}_{3}-\mathrm{C}-5\right), 0.92\left[\mathrm{~s}, 9 \mathrm{H}, \mathrm{SiC}\left(\mathrm{CH}_{3}\right)_{3}\right], 0.12\left(\mathrm{~s}, 6 \mathrm{H}, \mathrm{SiCH}_{3}\right) . \delta_{\mathrm{c}}$ (75 MHz; $\mathrm{CDCl}_{3}$ ): 163.8 (C, C-4), 150.5 (C, C-2), 135.5 (CH, C-6), $111.0(\mathrm{C}, \mathrm{C}-5), 87.3\left(\mathrm{CH}, \mathrm{C}-4^{\prime}\right), 85.0\left(\mathrm{CH}, \mathrm{C}-1^{\prime}\right), 72.6\left(\mathrm{CH}, \mathrm{C}-3^{\prime}\right)$, $63.6\left(\mathrm{CH}_{2}, \mathrm{C}-5^{\prime}\right), 41.1\left(\mathrm{CH}_{2}, \mathrm{C}-2^{\prime}\right), 26.0\left[\mathrm{CH}_{3}, \mathrm{SiC}\left(\mathrm{CH}_{3}\right)_{3}\right], 18.4[\mathrm{C}$, $\left.\mathrm{SiC}\left(\mathrm{CH}_{3}\right)_{3}\right], 12.5\left(\mathrm{CH}_{3}, \mathrm{CH}_{3}-\mathrm{C}-5\right),-5.4\left(\mathrm{CH}_{3}, \mathrm{SiCH}_{3}\right),-5.5$ $\left(\mathrm{CH}_{3}, \mathrm{SiCH}_{3}\right)$. HRMS (ES+) $m / z$ calcd for $\mathrm{C}_{16} \mathrm{H}_{29} \mathrm{~N}_{2} \mathrm{O}_{5} \mathrm{Si}[\mathrm{M}+$ $\mathrm{H}]^{+}$357.1846, found 357.1839. $v_{\max } \mathrm{cm}^{-1}$ (film) 3300, 2950, 1681, $1470,1273,1130,939,844$.

$\mathbf{5}^{\prime}$-O-tert-Butyldimethylsilyluridine (28a). ${ }^{41}$ Treatment of uridine $27 \mathrm{a}$ (3.00 g, $12.28 \mathrm{mmol})$, tert-butyldimethylsilyl chloride $(1.94 \mathrm{~g}, 12.90 \mathrm{mmol})$ and imidazole $(1.67 \mathrm{~g}, 24.57 \mathrm{mmol})$ in DMF $(30 \mathrm{~mL})$ by procedure A (chromatography with $\mathrm{CH}_{2} \mathrm{Cl}_{2}$ / $\mathrm{MeOH}, 98: 2$ to $95: 5)$ afforded the title product 28a as a white solid (4.10 g, 93\%). mp: 96-97 ${ }^{\circ} \mathrm{C}$ (lit.: $\left.{ }^{38} 85-88{ }^{\circ} \mathrm{C}\right) . \delta_{\mathrm{H}}(300$ $\left.\mathrm{MHz} ; \mathrm{CDCl}_{3}\right): 8.05(\mathrm{~d}, 1 \mathrm{H}, J=8.1 \mathrm{~Hz}, \mathrm{H}-6), 5.90(\mathrm{~d}, 1 \mathrm{H}, J=$ $\left.2.1 \mathrm{~Hz}, \mathrm{H}-1^{\prime}\right), 5.66(\mathrm{~d}, 1 \mathrm{H}, J=8.1 \mathrm{~Hz}, \mathrm{H}-5), 4.25-4.23(\mathrm{~m}, 2 \mathrm{H}$, $\mathrm{H}-3^{\prime}, \mathrm{H}-2^{\prime}$ ), 4.15-4.14 (m, 1H, H-4'), 4.02 (A part of ABX system, $1 \mathrm{H}, J=11.7,1.8 \mathrm{~Hz}$, one of $\mathrm{H}-5^{\prime}$ ), 3.84 (B part of ABX system, $1 \mathrm{H}$, $J=11.7,1.5 \mathrm{~Hz}$, one of $\left.\mathrm{H}-5^{\prime}\right), 0.92\left[\mathrm{~s}, 9 \mathrm{H}, \mathrm{SiC}\left(\mathrm{CH}_{3}\right)_{3}\right], 0.11(\mathrm{~s}, 6 \mathrm{H}$, $\left.\mathrm{SiCH}_{3}\right) . \delta_{\mathrm{c}}\left(75 \mathrm{MHz} ; \mathrm{CDCl}_{3}\right): 164.0(\mathrm{C}, \mathrm{C}-4), 151.4(\mathrm{C}, \mathrm{C}-2), 140.5$ (CH, C-6), $102.1(\mathrm{CH}, \mathrm{C}-5), 90.1\left(\mathrm{CH}, \mathrm{C}-1^{\prime}\right), 85.0\left(\mathrm{CH}, \mathrm{C}-4^{\prime}\right), 75.7$ $\left(\mathrm{CH}, \mathrm{C}-3^{\prime}\right), 69.4\left(\mathrm{CH}_{2}, \mathrm{C}-2^{\prime}\right), 61.9\left(\mathrm{CH}_{2}, \mathrm{C}-5^{\prime}\right), 25.9\left[\mathrm{CH}_{3}, \mathrm{SiC}-\right.$ $\left.\left(\mathrm{CH}_{3}\right)_{3}\right], 18.4\left[\mathrm{C}, \mathrm{SiC}\left(\mathrm{CH}_{3}\right)_{3}\right],-5.5\left(\mathrm{CH}_{3}, \mathrm{SiCH}_{3}\right) . \mathrm{MS}(\mathrm{ES}+) m / z$ $\left[\mathrm{M}+\mathrm{CH}_{3} \mathrm{CN}\right]^{+} 400.1(100 \%), 359.1(20 \%), 281.1(16 \%), 242.2$ (20\%), $104.9(70 \%), 68.8(20 \%), 42.0(30 \%)$.

$\mathbf{5}^{\prime}$-O-tert-Butyldimethylsilyl-5-methyluridine (24a). ${ }^{42}$ Treatment of 5-methyluridine 23a (3.00 g, $12.28 \mathrm{mmol})$, tert-butyldimethylsilyl chloride $(6.13 \mathrm{~g}, 40.7 \mathrm{mmol})$ and imidazole $(1.67 \mathrm{~g}$, $77.00 \mathrm{mmol})$ in DMF $(30 \mathrm{~mL})$ by procedure A (chromatography with $\left.\mathrm{CH}_{2} \mathrm{Cl}_{2} / \mathrm{MeOH}, 98: 2\right)$ afforded the title product 24a (12.2 g, $85 \%) . \delta_{\mathrm{H}}\left(300 \mathrm{MHz} ; \mathrm{CDCl}_{3}\right): 9.60(\mathrm{bs}, 1 \mathrm{H}, \mathrm{NH}), 7.59$ (finely split s, $1 \mathrm{H}, \mathrm{H}-6), 5.92\left(\mathrm{~d}, 1 \mathrm{H}, J=3.0 \mathrm{~Hz}, \mathrm{H}-1^{\prime}\right), 5.10$ (bs, $1 \mathrm{H}$, OH), 4.25-4.19 (m, 3H, H-2', H-3' H-4 $^{\prime}$ ), 3.97 (A part of ABX, $1 \mathrm{H}, J=11.4,1.8 \mathrm{~Hz}$, one $\left.\mathrm{H}-5^{\prime}\right), 3.83$ (B part of ABX, $1 \mathrm{H}, J=$ 11.4, $1.8 \mathrm{~Hz}$, one $\mathrm{H}^{-5}$ ), 3.41 (bs, $\left.1 \mathrm{H}, \mathrm{OH}\right), 1.89$ (s, $3 \mathrm{H}, \mathrm{CH}_{3}$ ),

(40) (a) Ogilvie, K. K.; Iwacha, D. J. Tetrahedron Lett. 1973, 317. (b) Ogilvie, K. K. Can. J. Chem. 1973, 51, 3799.

(41) Szarek, W. A.; Pinto, M. B.; Iwakawa, M. Can. J. Chem. 1985, 63, 2149 .

(42) Nair, V.; Buenger, G. S. Org. Prep. Proceed. Int. 1990, 22, 57. 
0.92, [s, 9H, $\left.\mathrm{SiC}\left(\mathrm{CH}_{3}\right)_{3}\right], 0.11\left(\mathrm{~s}, 6 \mathrm{H}, \mathrm{SiCH}_{3}\right) . \delta_{\mathrm{c}}(75 \mathrm{MHz}$; $\left.\mathrm{CDCl}_{3}\right): 164.1(\mathrm{C}, \mathrm{C}-4), 151.5(\mathrm{C}, \mathrm{C}-2), 135.6(\mathrm{CH}, \mathrm{C}-6), 110.7$ (C, C-5), $90.3\left(\mathrm{CH}, \mathrm{C}^{-1}{ }^{\prime}\right), 85.9\left(\mathrm{CH}, \mathrm{C}-4^{\prime}\right), 76.0\left(\mathrm{CH}, \mathrm{C}-3^{\prime}\right), 70.8$ $\left(\mathrm{CH}, \mathrm{C}-2^{\prime}\right), 62.8\left(\mathrm{CH}_{2}, \mathrm{C}-5^{\prime}\right), 25.9\left[\mathrm{CH}_{3}, \mathrm{SiC}\left(\mathrm{CH}_{3}\right)_{3}\right], 18.4[\mathrm{C}$, $\left.\mathrm{SiC}\left(\mathrm{CH}_{3}\right)_{3}\right], 12.5\left(\mathrm{CH}_{3}, \mathrm{CH}_{3}-\mathrm{C} 5\right),-5.5\left(\mathrm{CH}_{3}, \mathrm{SiCH}_{3}\right) . \mathrm{HRMS}$ $(\mathrm{ES}+) \mathrm{m} / z$ calcd for $\mathrm{C}_{16} \mathrm{H}_{29} \mathrm{~N}_{2} \mathrm{O}_{6} \mathrm{Si}[\mathrm{M}+\mathrm{H}]^{+} 373.1777$, found 373.1795

$\mathbf{5}^{\prime}$-O-tert-Butyldimethylsilyl-2'-deoxyuridine $(\mathbf{2 8 b}){ }^{43}$ Treatment of $2^{\prime}$-deoxyuridine $\mathbf{2 7 b}(1.00 \mathrm{~g}, 4.38 \mathrm{mmol})$, tert-butyldimethylsilyl chloride (693 mg, $4.60 \mathrm{mmol})$ and imidazole (600 $\mathrm{mg}$, $8.76 \mathrm{mmol}$ ) in DMF $(20 \mathrm{~mL})$ by procedure A (chromatography using EtOAc/hexane, 80:20) afforded the title product $\mathbf{2 8 \mathbf { b }}$ as a white solid $(1.03 \mathrm{~g}, 69 \%)$. mp: $136-137{ }^{\circ} \mathrm{C}$ (lit.: $\left.{ }^{40} 127-129^{\circ} \mathrm{C}\right)$. $\delta_{\mathrm{H}}\left(300 \mathrm{MHz} ; \mathrm{CDCl}_{3}\right): 9.61($ br s, $1 \mathrm{H}, \mathrm{NH}), 7.93(\mathrm{~d}, 1 \mathrm{H}, J=8.1$ $\mathrm{Hz}, \mathrm{H}-6), 6.36\left(\mathrm{t}, 1 \mathrm{H}, J=6.6 \mathrm{~Hz}, \mathrm{H}-1^{\prime}\right), 5.69(\mathrm{~d}, 1 \mathrm{H}, J=8.1 \mathrm{~Hz}$, H-5), 4.49-4.41 (m, 1H, H-3') , 4.09-4.04 (m, 1H, H-4'), 3.35 (d, $1 \mathrm{H}, J=4.2 \mathrm{~Hz}, \mathrm{OH}), 3.91$ (A part of ABX, $1 \mathrm{H}, J=11.4,2.4 \mathrm{~Hz}$, H-5') 3.83 (B part of ABX, $\left.1 \mathrm{H}, J=11.4,2.1 \mathrm{~Hz}, \mathrm{H}-5^{\prime}\right), 2.44$ $\left(\mathrm{ddd}, 1 \mathrm{H}, J=9.3,6.0,3.3 \mathrm{~Hz}\right.$, one of the $\left.\mathrm{H}-2^{\prime}\right), 2.15-2.09(\mathrm{~m}$, $1 \mathrm{H}$, one of the $\left.\mathrm{H}-2^{\prime}\right), 0.91\left[\mathrm{~s}, 9 \mathrm{H}, \mathrm{SiC}\left(\mathrm{CH}_{3}\right)_{3}\right], 0.10(\mathrm{~s}, 6 \mathrm{H}$, $\left.\mathrm{SiCH}_{3}\right) . \delta_{\mathrm{c}}\left(75 \mathrm{MHz} ; \mathrm{CDCl}_{3}\right): 163.6(\mathrm{C}, \mathrm{C}-4), 150.5(\mathrm{C}, \mathrm{C}-2)$, $140.3(\mathrm{CH}, \mathrm{C}-6), 102.3(\mathrm{CH}, \mathrm{C}-5), 87.5\left(\mathrm{CH}, \mathrm{C}-4^{\prime}\right), 85.4(\mathrm{CH}$, $\left.\mathrm{C}-1^{\prime}\right), 71.9\left(\mathrm{CH}, \mathrm{C}-3^{\prime}\right), 63.3\left(\mathrm{CH}_{2}, \mathrm{C}-5^{\prime}\right), 41.5\left(\mathrm{CH}_{2}, \mathrm{C}-2^{\prime}\right), 25.7$ $\left[\mathrm{CH}_{3}, \mathrm{SiC}\left(\mathrm{CH}_{3}\right)_{3}\right], 18.3\left[\mathrm{C}, \mathrm{SiC}\left(\mathrm{CH}_{3}\right)_{3}\right],-5.5\left(\mathrm{CH}_{3}, \mathrm{SiCH}_{3}\right),-5.6$ $\left(\mathrm{CH}_{3}, \mathrm{SiCH}_{3}\right.$ ). HRMS (ES+) $m / z$ calcd for $\mathrm{C}_{15} \mathrm{H}_{27} \mathrm{~N}_{2} \mathrm{O}_{5} \mathrm{Si}$ $[\mathrm{M}+\mathrm{H}]^{+}$343.1689, found 343.1702. $v_{\max } \mathrm{cm}^{-1}$ (film) 2929, 2857, $1686,1464,1388,1275,1123,836$.

5'-O-tert-Butyldimethylsilylcytidine (32a). Treatment of cytidine 31a (5.00 g, $20.56 \mathrm{mmol})$, tert-butyldimethylsilyl chloride $(3.25 \mathrm{~g}, 21.59 \mathrm{mmol})$ and imidazole $(2.80 \mathrm{~g}, 41.1 \mathrm{mmol})$ in DMF $\left(40 \mathrm{~mL}\right.$ ) by procedure $\mathrm{A}$ (chromatography using $\mathrm{CH}_{2} \mathrm{Cl}_{2}$ / $\mathrm{MeOH}, 95: 5)$ afforded the title product 32a as a colorless foam $(6.70 \mathrm{~g}, 91 \%) . \delta_{\mathrm{H}}\left(300 \mathrm{MHz} ; \mathrm{CDCl}_{3}\right): 7.94(\mathrm{~d}, 1 \mathrm{H}, J=7.5 \mathrm{~Hz}$, H-6), 5.95 (bs, $1 \mathrm{H}, \mathrm{H}_{-1}^{\prime}$ ), 5.76 (d, 1H, $\left.J=7.5 \mathrm{~Hz}, \mathrm{H}-5\right), 4.20-$ $4.12\left(\mathrm{~m}, 3 \mathrm{H}, \mathrm{H}-3^{\prime}, \mathrm{H}-4^{\prime}, \mathrm{H}-2^{\prime}\right), 3.95$ (A part of ABX, 1H, $J=$ $10.8 \mathrm{~Hz}$, one of $\left.\mathrm{H}^{-} 5^{\prime}\right), 3.80(\mathrm{~B}$ part of $\mathrm{ABX}, 1 \mathrm{H}, J=10.8 \mathrm{~Hz}$, one of $\left.\mathrm{H}-5^{\prime}\right), 0.88$ [s, 9H, $\left.\mathrm{SiC}\left(\mathrm{CH}_{3}\right)_{3}\right], 0.07\left(\mathrm{~s}, 6 \mathrm{H}, \mathrm{SiCH}_{3}\right) . \delta_{\mathrm{c}}(75$ $\mathrm{MHz} ; \mathrm{CDCl}_{3}$ ): 165.7 (C, C-4), 157.1 (C, C-2), 141.2 (CH, C-6), $94.8(\mathrm{CH}, \mathrm{C}-5), 91.00\left(\mathrm{CH}, \mathrm{C}-1^{\prime}\right), 85.4\left(\mathrm{CH}, \mathrm{C}-4^{\prime}\right), 76.6(\mathrm{CH}$, $\left.\mathrm{C}-3^{\prime}\right), 70.5\left(\mathrm{CH}, \mathrm{C}-2^{\prime}\right), 62.6\left(\mathrm{CH}_{2}, \mathrm{C}-5^{\prime}\right), 25.9\left[\mathrm{CH}_{3}, \mathrm{SiC}\left(\mathrm{CH}_{3}\right)_{3}\right]$, $18.4\left[\mathrm{C}, \mathrm{SiC}\left(\mathrm{CH}_{3}\right)_{3}\right],-5.5\left(\mathrm{CH}_{3}, \mathrm{SiCH}_{3}\right)$. HRMS (ES+) $m / z$ calcd for $\mathrm{C}_{15} \mathrm{H}_{28} \mathrm{~N}_{3} \mathrm{O}_{5} \mathrm{Si}[\mathrm{M}+\mathrm{H}]^{+} 358.1798$, found 358.1791 .

5 '-O-tert-Butyldimethylsilyl-2'-deoxycytidine (32b). Treatment of $2^{\prime}$-deoxycytidine $31 \mathrm{~b}(5.00 \mathrm{~g}, 22.01 \mathrm{mmol})$, tert-butyldimethylsilyl chloride $(3.48 \mathrm{~g}, 23.11 \mathrm{mmol})$ and imidazole $(3.00 \mathrm{~g}, 44.00$ $\mathrm{mmol})$ in DMF $(40 \mathrm{~mL})$ by procedure A (chromatography using $\mathrm{CH}_{2} \mathrm{Cl}_{2} / \mathrm{MeOH}, 90: 10$ ) afforded the title product 32b as a white solid $(6.70 \mathrm{~g}, 91 \%)$. mp: $211-212^{\circ} \mathrm{C} . \delta_{\mathrm{H}}\left(300 \mathrm{MHz} ; \mathrm{d}^{6}-\mathrm{DMSO}\right)$ : $7.76(\mathrm{~d}, 1 \mathrm{H}, J=7.2 \mathrm{~Hz}, \mathrm{H}-6), 7.11$ (bs, $\left.2 \mathrm{H}, \mathrm{NH}_{2}\right), 6.15$ (t, $1 \mathrm{H}, J=$ $\left.6.0 \mathrm{~Hz}, \mathrm{H}-1^{\prime}\right), 5.69$ (d, 1H, $\left.J=7.2 \mathrm{~Hz}, \mathrm{H}-5\right), 5.23$ (bs, 1H, OH), 4.19-4.12 (bs, $\left.1 \mathrm{H}, \mathrm{H}-4^{\prime}\right), 3.82-3.69$ (m, 3H, H-3', H-5'), 2.20-2.11 (m, 1H, H-2'), 1.97-1.85 (m, 1H, H-2'), $0.88[\mathrm{~s}, 9 \mathrm{H}$, $\left.\mathrm{SiC}\left(\mathrm{CH}_{3}\right)_{3}\right], 0.07\left(\mathrm{~s}, 6 \mathrm{H}, \mathrm{SiCH}_{3}\right) . \delta_{\mathrm{c}}\left(75 \mathrm{MHz} ; \mathrm{d}^{6}-\mathrm{DMSO}\right): 165.5$ (C, C-4), 154.9 (C, C-2), 140.4 (CH, C-6), 93.6 (CH, C-5), 86.6 $\left(\mathrm{CH}, \mathrm{C}-1^{\prime}\right), 84.8\left(\mathrm{CH}, \mathrm{C}-4^{\prime}\right), 70.0\left(\mathrm{CH}, \mathrm{C}-3^{\prime}\right), 62.9\left(\mathrm{CH}_{2}, \mathrm{C}-5^{\prime}\right), 40.7$ $\left(\mathrm{CH}_{2}, \mathrm{C}-2^{\prime}\right), 25.7\left[\mathrm{CH}_{3}, \mathrm{SiC}\left(\mathrm{CH}_{3}\right)_{3}\right], 17.9\left[\mathrm{C}, \mathrm{SiC}\left(\mathrm{CH}_{3}\right)_{3}\right],-5.6$ $\left(\mathrm{CH}_{3}, \mathrm{SiCH}_{3}\right)$. HRMS (ES+) $m / z$ calcd for $\mathrm{C}_{15} \mathrm{H}_{28} \mathrm{~N}_{3} \mathrm{O}_{4} \mathrm{Si}[\mathrm{M}+$ $\mathrm{H}]^{+} 342.1849$, found 342.1846 .

5'-O-tert-Butyldimethylsilyladenosine $(36 \mathbf{a}) .{ }^{44}$ Treatment of adenosine $35 \mathrm{a}(5.00 \mathrm{~g}, 18.7 \mathrm{mmol})$, tert-butyldimethylsilyl chloride $(3.38 \mathrm{~g}, 22.45 \mathrm{mmol})$ and imidazole $(2.55 \mathrm{~g}, 37.4 \mathrm{mmol})$ in DMF $\left(40 \mathrm{~mL}\right.$ ) by procedure A (chromatography using $\mathrm{CH}_{2} \mathrm{Cl}_{2}$ / $\mathrm{MeOH}, 90: 10)$ afforded the product 36a as a white solid $(4.85 \mathrm{~g}$,

(43) Moharram, S.; Zhou, A.; Wiebe, L. I.; Knaus, E. E. J. Med. Chem. 2004, 47, 1840 .

(44) Breton, F.; Delepee, R.; Jegourel, D.; Deville-Bonne, D.; Agrofoglio, L. A. Anal. Chim. Acta 2008, 616, 222.
$68 \%$ ). mp: $178-179^{\circ} \mathrm{C} . \delta_{\mathrm{H}}\left(300 \mathrm{MHz} ; \mathrm{CDCl}_{3}\right): 8.36(\mathrm{~s}, 1 \mathrm{H}, \mathrm{H}-2$ or $\mathrm{H}-8), 8.26(\mathrm{~s}, 1 \mathrm{H}, \mathrm{H}-2$ or $\mathrm{H}-8), 6.00\left(\mathrm{~d}, 1 \mathrm{H}, J=2.7 \mathrm{~Hz}, \mathrm{H}-1^{\prime}\right)$, 4.39-4.32 (m, 2H, H-3', H-2'), 4.23-4.20 (m, 1H, H-4'), 4.06 (A part of ABX, $1 \mathrm{H}, J=11.7,2.4 \mathrm{~Hz}$, one $\left.\mathrm{H}-5^{\prime}\right), 3.88$ (B part of ABX, $1 \mathrm{H}, J=11.7,2.1 \mathrm{~Hz}$, one $\left.\mathrm{H}-5^{\prime}\right), 0.91\left[\mathrm{~s}, 9 \mathrm{H}, \mathrm{SiC}\left(\mathrm{CH}_{3}\right)_{3}\right]$, $0.12\left(\mathrm{~s}, 6 \mathrm{H}, \mathrm{SiCH}_{3}\right) . \delta_{\mathrm{c}}\left(75 \mathrm{MHz} ; \mathrm{CDCl}_{3}\right): 152.4(\mathrm{CH}, \mathrm{C}-2), 138.8$ $(\mathrm{CH}, \mathrm{C}-8), 90.0\left(\mathrm{CH}, \mathrm{C}-1^{\prime}\right), 85.4\left(\mathrm{CH}, \mathrm{C}-4^{\prime}\right), 75.7\left(\mathrm{CH}, \mathrm{C}-2^{\prime}\right)$, $69.5\left(\mathrm{CH}, \mathrm{C}-3^{\prime}\right), 62.1\left(\mathrm{CH}_{2}, \mathrm{C}-5^{\prime}\right), 25.9\left[\mathrm{CH}_{3}, \mathrm{SiC}\left(\mathrm{CH}_{3}\right)_{3}\right], 18.5$ $\left[\mathrm{C}, \mathrm{SiC}\left(\mathrm{CH}_{3}\right)_{3}\right],-5.5\left(\mathrm{CH}_{3}, \mathrm{SiCH}_{3}\right)$. C-6, C-5, and C-4 could not be detected. HRMS (ES+) $m / z$ calcd for $\mathrm{C}_{16} \mathrm{H}_{28} \mathrm{~N}_{5} \mathrm{O}_{4} \mathrm{Si}$ $[\mathrm{M}+\mathrm{H}]^{+} 382.1911$, found 382.1902 .

$\mathbf{5}^{\prime}$-O-tert-Butyldimethylsilyl-2'-deoxyadenosine $(\mathbf{3 6 b}){ }^{45}$ Treatment of $2^{\prime}$-deoxyadenosine $\mathbf{3 5 b}$ (coevaporated with dry pyridine) (5.00 g, $19.90 \mathrm{mmol})$, tert-butyldimethylsilyl chloride (3.15 g, 20.90 mmol) and imidazole $(2.71 \mathrm{~g}, 39.80 \mathrm{mmol})$ in DMF $(50 \mathrm{~mL})$ by procedure A (chromatography using $\mathrm{CH}_{2} \mathrm{Cl}_{2} / \mathrm{MeOH}$, 95:5 to 90:10) afforded the title product $\mathbf{3 6} \mathbf{b}$ as a white solid (4.09 g, $72 \%$ ). mp: $125-126{ }^{\circ} \mathrm{C}$ (lit.: $\left.{ }^{42} 169-170{ }^{\circ} \mathrm{C}\right) . \delta_{\mathrm{H}}(300 \mathrm{MHz}$; $\left.\mathrm{CDCl}_{3}\right): 8.36(\mathrm{~s}, 1 \mathrm{H}, \mathrm{H}-2$ or $\mathrm{H}-8), 8.25(\mathrm{~s}, 1 \mathrm{H}, \mathrm{H}-2$ or $\mathrm{H}-8), 6.59$ $\left(\mathrm{t}, 1 \mathrm{H}, J=6.3 \mathrm{~Hz}, \mathrm{H}-1^{\prime}\right), 6.52$ (bs, 2H, NH$), 5.16$ (bs, 1H, $3^{\prime}-$ $\mathrm{OH}), 4.75-4.69\left(\mathrm{~m}, 1 \mathrm{H}, \mathrm{H}-3^{\prime}\right), 4.22-4.19$ (X part of ABX, $1 \mathrm{H}$, $\left.J=6.3,3.0 \mathrm{~Hz}, \mathrm{H}-4^{\prime}\right), 3.95(\mathrm{~A}$ part of ABX, $1 \mathrm{H}, J=11.4,3.9 \mathrm{~Hz}$, one of $\mathrm{H}-5^{\prime}$ ), 3.89 (B part of ABX, 1H, $J=11.1,3.3 \mathrm{~Hz}$, one of $\left.\mathrm{H}-5^{\prime}\right), 2.75-2.59\left(\mathrm{~m}, 2 \mathrm{H}, \mathrm{H}-2^{\prime}\right), 0.92$, [s, 9H, SiC $\left.\left(\mathrm{CH}_{3}\right)_{3}\right], 0.12$ (s, $\left.6 \mathrm{H}, \mathrm{SiCH}_{3}\right) . \delta \mathrm{c}\left(75 \mathrm{MHz} ; \mathrm{CDCl}_{3}\right): 155.7(\mathrm{C}, \mathrm{C}-6), 152.8(\mathrm{CH}, \mathrm{C}-2)$, 149.3 (C, C-4), 138.8 (CH, C-8), 119.6 (C, C-5), $87.4\left(\mathrm{CH}, \mathrm{C}-4^{\prime}\right)$, $84.4\left(\mathrm{CH}, \mathrm{C}-1^{\prime}\right), 71.6\left(\mathrm{CH}, \mathrm{C}-3^{\prime}\right), 63.4\left(\mathrm{CH}_{2}, \mathrm{C}-5^{\prime}\right), 41.5\left(\mathrm{CH}_{2}\right.$, C-2' $), 25.9\left[\mathrm{CH}_{3}, \mathrm{SiC}\left(\mathrm{CH}_{3}\right)_{3}\right], 18.3\left[\mathrm{C}, \mathrm{SiC}\left(\mathrm{CH}_{3}\right)_{3}\right],-5.4\left[\mathrm{CH}_{3}\right.$, $\left.\mathrm{Si}\left(\mathrm{CH}_{3}\right)_{2}\right]$. HRMS $\left(\mathrm{ES}^{+}\right) \mathrm{m} / z$ calcd for $\mathrm{C}_{16} \mathrm{H}_{28} \mathrm{~N}_{5} \mathrm{O}_{3} \mathrm{Si}[\mathrm{M}+\mathrm{H}]^{+}$ 366.1961, found 366.1962.

Procedure B: Benzoylation. 5'-O-tert-Butyldimethylsilyl-3' $\boldsymbol{O}, \mathbf{3}-\mathrm{N}$-dibenzoylthymidine $\mathbf{( 2 5 b )}{ }^{46}$ Benzoyl chloride (3.61 g, $3 \mathrm{~mL}, 25.7 \mathrm{mmol}$ ) was added dropwise to an ice cold solution of 5'-O-tert-butyldimethylsilylthymidine $\mathbf{2 4 b}(3.05 \mathrm{~g}, 8.56 \mathrm{mmol})$, triethylamine $(3.46 \mathrm{~g}, 4.77 \mathrm{~mL}, 34.2 \mathrm{mmol})$ and dimethylaminopyridine $(0.2 \mathrm{~g}, 1.64 \mathrm{mmol})$ in dichloromethane $(40 \mathrm{~mL})$. The resulting mixture was stirred at room temperature overnight. Saturated $\mathrm{NaHCO}_{3}(30 \mathrm{~mL})$ was added slowly and stirring was continued until complete hydrolysis of benzoyl chloride as evidenced by completion of $\mathrm{CO}_{2}$ release. The layers were then separated and the aqueous phase extracted twice with dichloromethane $(2 \times 20$ $\mathrm{mL}$ ). The combined organic phases were washed twice with $2 \mathrm{M}$ $\mathrm{HCl}(2 \times 20 \mathrm{~mL})$, once with water $(30 \mathrm{~mL})$, dried over magnesium sulfate and concentrated in vacuo. The crude product was purified by flash chromatography using hexane/EtOAc, 70:30) to afford the title product $25 \mathrm{~b}$ as a white solid $(4.3 \mathrm{~g}, 89 \%)$. mp: $78-79^{\circ} \mathrm{C} . \delta_{\mathrm{H}}$ $\left(300 \mathrm{MHz} ; \mathrm{CDCl}_{3}\right): 8.02-8.00\left(\mathrm{~m}, 2 \mathrm{H}, \mathrm{ArH}_{\text {ortho }}\right), 7.95-7.93(\mathrm{~m}$, $2 \mathrm{H}, \mathrm{ArH}_{\text {ortho }}$ ), 7.72 (finely split s, $\left.1 \mathrm{H}, \mathrm{H}-6\right), 7.67-7.63(\mathrm{~m}, 1 \mathrm{H}$, $\left.\mathrm{ArH}_{\text {para }}\right), 7.60-7.57\left(\mathrm{~m}, 1 \mathrm{H}, \mathrm{ArH}_{\text {para }}\right), 7.52-7.42\left(\mathrm{~m}, 4 \mathrm{H}, \mathrm{ArH}_{\text {meta }}\right)$, $6.48\left(\mathrm{dd}, 1 \mathrm{H}, J=9.3,5.2 \mathrm{~Hz}, \mathrm{H}-1^{\prime}\right), 5.52\left(\mathrm{~d}, 1 \mathrm{H}, J=6.0 \mathrm{~Hz}, \mathrm{H}-3^{\prime}\right)$, 4.28 (bs, 1H, H-4'), 4.06 (A part of ABX system, $1 \mathrm{H}, J=11.3,1.9$ $\mathrm{Hz}$, one of $\mathrm{H}-5^{\prime}$ ), 4.01 (B part of ABX system, $1 \mathrm{H}, J=11.3,1.9 \mathrm{~Hz}$, one of $\left.\mathrm{H}^{-} 5^{\prime}\right), 2.62\left(\mathrm{dd}, 1 \mathrm{H}, J=13.8,5.5 \mathrm{~Hz}\right.$, one of $\left.\mathrm{H}-2^{\prime}\right), 2.29(\mathrm{ddd}$, $1 \mathrm{H}, J=13.7,9.2,6.0 \mathrm{~Hz}$, one of $\left.\mathrm{H}-2^{\prime}\right), 1.99\left(\mathrm{~s}, 3 \mathrm{H}, \mathrm{CH}_{3}\right), 0.99[\mathrm{~s}$, $\left.9 \mathrm{H}, \mathrm{C}\left(\mathrm{CH}_{3}\right)_{3}\right], 0.20\left(\mathrm{~s}, 6 \mathrm{H}, 2 \times \mathrm{SiCH}_{3}\right) . \delta_{\mathrm{c}}\left(75 \mathrm{MHz} ; \mathrm{CDCl}_{3}\right): 168.9$ (C, NCOPh), 166.1 (C, OCOPh), 162.8 (C, C-4), 149.4 (C, C-2), $135.0(\mathrm{CH}, \mathrm{C}-6), 134.9(\mathrm{CH}), 133.6(\mathrm{CH}), 131.6(\mathrm{C}), 130.5(\mathrm{CH})$, $129.7(\mathrm{CH}), 129.2(\mathrm{CH}), 129.1(\mathrm{C}), 128.6(\mathrm{CH}), 111.4(\mathrm{C}, \mathrm{C}-5), 85.7$, $85.0\left(2 \times \mathrm{CH}, \mathrm{C}-1^{\prime}, \mathrm{C}-4^{\prime}\right), 76.0\left(\mathrm{CH}, \mathrm{C}-3^{\prime}\right), 63.7\left(\mathrm{CH}_{2}, \mathrm{C}-5^{\prime}\right), 38.2$ $\left(\mathrm{CH}_{2}, \mathrm{C}-2^{\prime}\right), 26.0\left(\mathrm{CH}_{3}, \mathrm{SiC}\left(\mathrm{CH}_{3}\right)_{3}\right), 18.4\left[\mathrm{C}, \mathrm{SiC}\left(\mathrm{CH}_{3}\right)_{3}\right], 12.6$ $\left(\mathrm{CH}_{3}, \mathrm{CH}_{3}-\mathrm{C}-5\right),-5.3\left(\mathrm{CH}_{3}, \mathrm{SiCH}_{3}\right),-5.4\left(\mathrm{CH}_{3}, \mathrm{SiCH}_{3}\right) . \mathrm{MS}$ $(\mathrm{ES}+) m / z[\mathrm{M}+\mathrm{H}]^{+} 565.1(100 \%), 443.1(26 \%) \cdot v_{\max } \mathrm{cm}^{-1}$ (film) $3068,2930,1753,1710,1667,1449,1270,1109,834$.

(45) Maguire, A. R.; Meng, W-D ; Roberts, S. M ; Willetts, A. J J. Chem. Soc. Perkin Trans 1 1993, 15, 1795.

(46) Roy, V.; Colombeau, L.; Zerrouki, R.; Krausz, P. Carbohydr. Res. 2004, 339, 1829. 
$\mathbf{5}^{\prime}$-O-tert-Butyldimethylsilyl-2', $\mathbf{3}^{\prime}$-O,3- $\mathrm{N}$-tribenzoyluridine (29a). ${ }^{24}$ Treatment of $28 \mathrm{a}(1.00 \mathrm{~g}, 2.79 \mathrm{mmol})$, benzoyl chloride $(2.35 \mathrm{~g}$, $1.90 \mathrm{~mL}, 16.74 \mathrm{mmol})$, triethylamine $(1.69 \mathrm{~g}, 2.33 \mathrm{~mL}, 16.74 \mathrm{mmol})$ and dimethylaminopyridine $(70 \mathrm{mg}, 0.55 \mathrm{mmol})$ in $\mathrm{CH}_{2} \mathrm{Cl}_{2}(40$ $\mathrm{mL}$ ) by procedure $\mathrm{B}$ (chromatography using hexane/EtOAc, 80:20) afforded the title product 29a as a colorless foam $(1.40 \mathrm{~g}$, $75 \%) . \delta_{\mathrm{H}}\left(300 \mathrm{MHz} ; \mathrm{CDCl}_{3}\right): 8.13(\mathrm{~d}, 1 \mathrm{H}, J=8.1 \mathrm{~Hz}, \mathrm{H}-6), 8.04-$ 7.89 (m, 6H, ArH ortho $), 7.62-7.49$ (m, 3H, ArH $\mathrm{Aara}), 7.44-7.28$ $\left(\mathrm{m}, 6 \mathrm{H}, \mathrm{ArH}_{\text {meta }}\right), 6.60\left(\mathrm{~d}, 1 \mathrm{H}, J=7.2 \mathrm{~Hz}, \mathrm{H}-1^{\prime}\right), 5.94(\mathrm{~d}, 1 \mathrm{H}, J=$ $8.4 \mathrm{~Hz}, \mathrm{H}-5), 5.79$ (dd, $\left.1 \mathrm{H}, J=5.4,1.5 \mathrm{~Hz}, \mathrm{H}-3^{\prime}\right), 5.68$ (dd, $1 \mathrm{H}$, $\left.J=7.2,5.4 \mathrm{~Hz}, \mathrm{H}-2^{\prime}\right), 4.52-4.49\left(\mathrm{~m}, 1 \mathrm{H}, \mathrm{H}-4^{\prime}\right), 4.08-4.06(\mathrm{~m}, 2 \mathrm{H}$, $\left.\mathrm{H}-5^{\prime}\right), 1.05\left[\mathrm{~s}, 9 \mathrm{H}, \mathrm{C}\left(\mathrm{CH}_{3}\right)_{3}\right], 0.27\left(\mathrm{~s}, 3 \mathrm{H}, \mathrm{SiCH}_{3}\right), 0.25$ (s, 3H, $\left.\mathrm{SiCH}_{3}\right) . \delta_{\mathrm{c}}\left(75 \mathrm{MHz} ; \mathrm{CDCl}_{3}\right): 168.4(\mathrm{C}, \mathrm{NCOPh}), 165.5(\mathrm{C}$, OCOPh), 165.4 (C, OCOPh), 161.8 (C, C-4), 149.6 (C, C-2), $139.3(\mathrm{CH}, \mathrm{C}-6), 134.9(\mathrm{CH}), 133.7(\mathrm{CH}), 133.6(\mathrm{CH}), 131.4(\mathrm{C})$, $130.5(\mathrm{CH}), 129.9(\mathrm{CH}), 129.8(\mathrm{CH}), 129.1(\mathrm{CH}), 128.9(\mathrm{C}), 128.6$ $(\mathrm{CH}), 128.5(\mathrm{CH}), 103.2(\mathrm{CH}, \mathrm{C}-5), 86.0\left(\mathrm{CH}, \mathrm{C}-1^{\prime}\right), 84.5(\mathrm{CH}$, C-4'), $74.5\left(\mathrm{CH}, \mathrm{C}-2^{\prime}\right), 72.9\left(\mathrm{CH}, \mathrm{C}-3^{\prime}\right), 63.5\left(\mathrm{CH}_{2}, \mathrm{C}-5^{\prime}\right), 26.0$ $\left[\mathrm{CH}_{3}, \mathrm{SiC}\left(\mathrm{CH}_{3}\right)_{3}\right], 18.4\left[\mathrm{C}, \mathrm{SiC}\left(\mathrm{CH}_{3}\right)_{3}\right],-5.4\left[\mathrm{CH}_{3}, \mathrm{Si}\left(\mathrm{CH}_{3}\right)_{2}\right]$. One aromatic $\mathrm{C}$ not detected. HRMS $(\mathrm{ES}+) \mathrm{m} / z$ calcd for $\mathrm{C}_{36} \mathrm{H}_{39^{-}}$ $\mathrm{N}_{2} \mathrm{O}_{9} \mathrm{Si}[\mathrm{M}+\mathrm{H}]^{+}$671.2425, found 671.2427.

$5^{\prime}$-O-tert-Butyldimethylsilyl-2', 3'-O,3- $N$-tribenzoyl-5-methyluridine (25a). Treatment of $\mathbf{2 4 a}(7.00 \mathrm{~g}, 18.79 \mathrm{mmol})$, benzoyl chloride (13.21 g, $10.90 \mathrm{~mL}, 94.00 \mathrm{mmol})$, triethylamine $(11.41 \mathrm{~g}, 15.72 \mathrm{~mL}$, $113.00 \mathrm{mmol})$ and dimethylaminopyridine $(230 \mathrm{mg}, 1.88 \mathrm{mmol})$ in $\mathrm{CH}_{2} \mathrm{Cl}_{2}(150 \mathrm{~mL}$ ) by procedure $\mathrm{B}$ (chromatography using hexane/ EtOAc, 80:20) afforded the title product 25a as a colorless foam $(10.4 \mathrm{~g}, 81 \%) . \delta_{\mathrm{H}}\left(300 \mathrm{MHz} ; \mathrm{CDCl}_{3}\right): 8.00-7.88\left(\mathrm{~m}, 6 \mathrm{H}, \mathrm{ArH}_{\text {ortho }}\right)$, 7.72 (finely split s, $1 \mathrm{H}, \mathrm{H}-6), 7.59-7.47\left(\mathrm{~m}, 3 \mathrm{H}, \mathrm{ArH}_{\text {para }}\right), 7.42-7.27$ $\left(\mathrm{m}, 6 \mathrm{H}, \mathrm{ArH}_{\text {meta }}\right), 6.61\left(\mathrm{~d}, 1 \mathrm{H}, J=8.1 \mathrm{~Hz}, \mathrm{H}-1^{\prime}\right), 5.74(\mathrm{dd}, 1 \mathrm{H}, J=$ $\left.5.4,1.2 \mathrm{~Hz}, \mathrm{H}-3^{\prime}\right), 5.60\left(\mathrm{dd}, 1 \mathrm{H}, J=7.8,5.7 \mathrm{~Hz}, \mathrm{H}-2^{\prime}\right), 4.46-4.42$ $\left(\mathrm{m}, 1 \mathrm{H}, \mathrm{H}-4^{\prime}\right), 4.06\left(\mathrm{~d}, 2 \mathrm{H}, J=1.2 \mathrm{~Hz}, \mathrm{H}-5^{\prime}\right), 1.97\left(\mathrm{~s}, 3 \mathrm{H}, \mathrm{CH}_{3}\right), 1.03$ $\left[\mathrm{s}, 9 \mathrm{H}, \mathrm{SiC}\left(\mathrm{CH}_{3}\right)_{3}\right], 0.22\left(\mathrm{~s}, 3 \mathrm{H}, \mathrm{SiCH}_{3}\right), 0.21\left(\mathrm{~s}, 3 \mathrm{H}, \mathrm{SiCH}_{3}\right) . \delta_{\mathrm{c}}(75$ $\left.\mathrm{MHz} ; \mathrm{CDCl}_{3}\right): 168.5(\mathrm{C}, \mathrm{NCOPh}), 165.6(\mathrm{C}, \mathrm{OCOPh}), 165.4(\mathrm{C}$, OCOPh), 162.5 (C, C-4), 149.7 (C, C-2), 134.8 (CH, C-6), 134.4 $(\mathrm{CH}), 133.7(\mathrm{CH}), 133.6(\mathrm{CH}), 131.6(\mathrm{C}), 130.4(\mathrm{CH}), 129.9(\mathrm{CH})$, $129.7(\mathrm{CH}), 129.0(\mathrm{CH}), 129.0(\mathrm{C}), 128.6(\mathrm{CH}), 128.5(\mathrm{C}), 128.4$ $(\mathrm{CH}), 112.0(\mathrm{C}, \mathrm{C}-5), 85.1\left(\mathrm{CH}, \mathrm{C}-1^{\prime}\right), 84.4\left(\mathrm{CH}, \mathrm{C}-4^{\prime}\right), 73.9(\mathrm{CH}$, $\left.\mathrm{C}-3^{\prime}\right), 72.8\left(\mathrm{CH}, \mathrm{C}-2^{\prime}\right), 63.5\left(\mathrm{CH}_{2}, \mathrm{C}-5^{\prime}\right), 26.0\left[\mathrm{CH}_{3}, \mathrm{SiC}\left(\mathrm{CH}_{3}\right)_{3}\right]$, $18.4\left[\mathrm{C}, \mathrm{SiC}\left(\mathrm{CH}_{3}\right)_{3}\right], 12.6\left(\mathrm{CH}_{3}, \mathrm{CH}_{3}-\mathrm{C}-5\right),-5.4\left[\mathrm{CH}_{3}, \mathrm{Si}\left(\mathrm{CH}_{3}\right)_{2}\right]$. HRMS (ES+) $m / z$ calcd for $\mathrm{C}_{37} \mathrm{H}_{41} \mathrm{~N}_{2} \mathrm{O}_{9} \mathrm{Si}[\mathrm{M}+\mathrm{H}]^{+} 685.2581$, found 685.2579. $v_{\max } \mathrm{cm}^{-1}$ (film) 2929, 1728, 1668, 1450, 1264, 1121, $1094,838,710$.

$5^{\prime}$-O-tert-Butyldimethylsilyl-3'-O,3- $\mathrm{N}$-dibenzoyl-2' -deoxyuridine (29b). Treatment of $\mathbf{2 8 b}(980 \mathrm{mg}, 2.86 \mathrm{mmol})$, benzoyl chloride (1.61 g, $1.33 \mathrm{~mL}, 11.45 \mathrm{mmol})$, triethylamine $(1.16 \mathrm{~g}, 1.60 \mathrm{~mL}$, $11.45 \mathrm{mmol}$ ) and dimethylaminopyridine $(35 \mathrm{mg}, 0.286 \mathrm{mmol})$ in $\mathrm{CH}_{2} \mathrm{Cl}_{2}(20 \mathrm{~mL})$ by procedure $\mathrm{B}$ (chromatography using hexane/ EtOAc, 70:30) afforded the title product $\mathbf{2 9 b}$ as a white solid $(1.20$ g, $76 \%)$. mp: $68-69^{\circ} \mathrm{C} . \delta_{\mathrm{H}}\left(300 \mathrm{MHz} ; \mathrm{CDCl}_{3}\right): 8.08(\mathrm{~d}, 1 \mathrm{H}, J=$ $8.1 \mathrm{~Hz}, \mathrm{H}-6), 8.02-7.93$ (m, 4H, $\left.\mathrm{ArH}_{\text {ortho }}\right), 7.66-7.54(\mathrm{~m}, 2 \mathrm{H}$, $\left.\mathrm{ArH}_{\text {para }}\right), 7.50-7.40\left(\mathrm{~m}, 4 \mathrm{H}, \mathrm{ArH}_{\text {meta }}\right), 6.48(\mathrm{dd}, 1 \mathrm{H}, J=9.0,6.6$ $\left.\mathrm{Hz}, \mathrm{H}-1^{\prime}\right), 5.85(\mathrm{~d}, 1 \mathrm{H}, J=8.4 \mathrm{~Hz}, \mathrm{H}-5), 5.55-5.51\left(\mathrm{~m}, 1 \mathrm{H}, \mathrm{H}-3^{\prime}\right)$, $4.32-4.28\left(\mathrm{~m}, 1 \mathrm{H}, \mathrm{H}-4^{\prime}\right), 4.06-3.96\left(\mathrm{~m}, 2 \mathrm{H}, \mathrm{H}-5^{\prime}\right), 2.66(\mathrm{ddd}, 1 \mathrm{H}$, $J=14.1,5.4,0.9 \mathrm{~Hz}$, one $\left.\mathrm{H}-2^{\prime}\right), 2.33(\mathrm{ddd}, 1 \mathrm{H}, J=14.4,8.7,6.3$ $\mathrm{Hz}$, one $\left.\mathrm{H}-2^{\prime}\right), 0.96\left[\mathrm{~s}, 9 \mathrm{H}, \mathrm{SiC}\left(\mathrm{CH}_{3}\right)_{3}\right], 0.18\left(\mathrm{~s}, 3 \mathrm{H}, \mathrm{SiCH}_{3}\right), 0.17$ (s, $\left.3 \mathrm{H}, \mathrm{SiCH}_{3}\right) . \delta_{\mathrm{c}}\left(75 \mathrm{MHz} ; \mathrm{CDCl}_{3}\right): 168.7(\mathrm{C}, \mathrm{NCOPh}), 166.1(\mathrm{C}$, OCOPh), 162.0 (C, C-4), 149.3 (C, C-2), 139.7 (CH, C-6), 135.1 $(\mathrm{CH}), 133.6(\mathrm{CH}), 131.5(\mathrm{C}), 130.5(\mathrm{CH}), 129.7(\mathrm{CH}), 129.2(\mathrm{C})$, 129.2 (CH), 128.6 (CH), 102.6(CH, C-5), 85.9, 85.6 (2 × CH, C-4', $\left.\mathrm{C}-1^{\prime}\right), 75.9\left(\mathrm{CH}, \mathrm{C}-3^{\prime}\right), 63.8\left(\mathrm{CH}_{2}, \mathrm{C}-5^{\prime}\right), 38.7\left(\mathrm{CH}_{2}, \mathrm{C}-2^{\prime}\right), 25.9$ $\left[\mathrm{CH}_{3}, \mathrm{SiC}\left(\mathrm{CH}_{3}\right)_{3}\right], 18.3\left[\mathrm{C}, \mathrm{SiC}\left(\mathrm{CH}_{3}\right)_{3}\right],-5.5\left[\mathrm{CH}_{3}, \mathrm{Si}\left(\mathrm{CH}_{3}\right)_{2}\right]$. HRMS (ES+) $m / z$ calcd for $\mathrm{C}_{29} \mathrm{H}_{35} \mathrm{~N}_{2} \mathrm{O}_{7} \mathrm{Si}[\mathrm{M}+\mathrm{H}]^{+} 551.2214$, found 551.2217. $v_{\max } \mathrm{cm}^{-1}$ (film) 2929, 2857, 1751, 1710, 1673, 1449, 1374, 1270, 1109, 837, 713.

$5^{\prime}$-O-tert-Butyldimethylsilyl-2'-O,3'-O,4-N-tribenzoylcytidine (33a). ${ }^{24}$ Treatment of 32a (7.30 g, $\left.20.42 \mathrm{mmol}\right)$, benzoyl chloride (14.22 mL, $123.00 \mathrm{mmol})$, triethylamine $(17.10 \mathrm{~mL}, 123.00 \mathrm{mmol})$ and dimethylaminopyridine $(1.50 \mathrm{~g}, 12.25 \mathrm{mmol})$ in $\mathrm{CH}_{2} \mathrm{Cl}_{2}(50 \mathrm{~mL})$ by procedure $\mathrm{B}$ (chromatography using hexane/EtOAc, 80:20 to $50: 50)$ afforded the title product 33a as a solid $(8.75 \mathrm{~g}, 64 \%)$. The product contains around $20 \%$ of unidentified impurity. mp: $132-$ $133^{\circ} \mathrm{C} . \delta_{\mathrm{H}}\left(300 \mathrm{MHz} ; \mathrm{CDCl}_{3}\right): 8.47(\mathrm{~d}, 1 \mathrm{H}, J=7.5 \mathrm{~Hz}, \mathrm{H}-6), 8.00-$ 7.94 (m, 6H, ArH $\left.{ }_{\text {ortho }}\right), 7.63-7.48$ (m, 4H, H-5, $\left.\mathrm{ArH}_{\text {para }}\right), 7.42-$ $7.33\left(\mathrm{~m}, 6 \mathrm{H}, \mathrm{ArH}_{\text {meta }}\right), 6.77\left(\mathrm{~d}, 1 \mathrm{H}, J=6.0 \mathrm{~Hz}, \mathrm{H}-1^{\prime}\right), 5.79(\mathrm{dd}, 1 \mathrm{H}$, $\left.J=5.5,3.0 \mathrm{~Hz}, \mathrm{H}-3^{\prime}\right), 5.69$ (bt, $1 \mathrm{H}, J=6.0,5.7 \mathrm{~Hz}, \mathrm{H}-2^{\prime}$ ), 4.54$4.51\left(\mathrm{~m}, 1 \mathrm{H}, \mathrm{H}-4^{\prime}\right), 4.11$ (A part of ABX, $1 \mathrm{H}, J=11.7,1.8 \mathrm{~Hz}$, one of $\mathrm{H}-5^{\prime}$ ), 4.02 (B part of ABX, $J=11.7,1.5 \mathrm{~Hz}$, one of $\left.\mathrm{H}-5^{\prime}\right), 1.02[\mathrm{~s}$, $\left.9 \mathrm{H}, \mathrm{SiC}\left(\mathrm{CH}_{3}\right)_{3}\right], 0.23\left(\mathrm{~s}, 3 \mathrm{H}, \mathrm{SiCH}_{3}\right), 0.22\left(\mathrm{~s}, 3 \mathrm{H}, \mathrm{SiCH}_{3}\right) . \delta_{\mathrm{c}}(75$ $\left.\mathrm{MHz} ; \mathrm{CDCl}_{3}\right): 165.5(\mathrm{C}, \mathrm{NCOPh}), 165.2(\mathrm{C}, 2 \times \mathrm{OCOPh}), 162.9(\mathrm{C}$, C-4), 154.6(C, C-2), 144.6(CH, C-6), $133.6(\mathrm{CH}), 133.5(\mathrm{CH}), 133.2$ (C), $133.1(\mathrm{CH}), 130.0(\mathrm{CH}), 129.8(\mathrm{CH}), 129.0(\mathrm{C}), 129.9(\mathrm{CH})$, $128.7(\mathrm{C}), 128.5(\mathrm{CH}), 128.4(\mathrm{CH}), 128.0(\mathrm{CH}), 97.6(\mathrm{CH}, \mathrm{C}-5), 87.1$ $\left(\mathrm{CH}, \mathrm{C}-1^{\prime}\right), 84.3\left(\mathrm{CH}, \mathrm{C}-4^{\prime}\right), 75.5\left(\mathrm{CH}, \mathrm{C}-2^{\prime}\right), 72.1\left(\mathrm{CH}, \mathrm{C}-3^{\prime}\right), 63.0$ $\left(\mathrm{CH}_{2}, \mathrm{C}-5^{\prime}\right), 26.0\left[\mathrm{CH}_{3}, \mathrm{SiC}\left(\mathrm{CH}_{3}\right)_{3}\right], 18.4\left[\mathrm{C}, \mathrm{SiC}\left(\mathrm{CH}_{3}\right)_{3}\right],-5.4$ $\left(\mathrm{CH}_{3}, \mathrm{SiCH}_{3}\right),-5.5\left(\mathrm{CH}_{3}, \mathrm{SiCH}_{3}\right)$. HRMS (ES+) $m / z$ calcd for $\mathrm{C}_{36} \mathrm{H}_{40} \mathrm{~N}_{3} \mathrm{O}_{8} \mathrm{Si}[\mathrm{M}+\mathrm{H}]^{+}$670.2585, found 670.2580.

$\mathbf{5}^{\prime}$-O-tert-Butyldimethylsilyl-3' $-\mathrm{O}, \mathbf{4}-\mathrm{N}$-dibenzoyl-2' -deoxycytidine (33b). Treatment of 32b (5.60 g, $16.40 \mathrm{mmol})$, benzoyl chloride (4.57 mL, $39.40 \mathrm{mmol})$, triethylamine $(5.49 \mathrm{~mL}, 39.40 \mathrm{mmol})$ and dimethylaminopyridine ( $480 \mathrm{mg}, 3.94 \mathrm{mmol})$ in $\mathrm{CH}_{2} \mathrm{Cl}_{2}(50 \mathrm{~mL})$ by procedure B (chromatography using hexane/EtOAc, 50:50) afforded the title product 33b as a solid $(4.36 \mathrm{~g}, 48 \%)$. Product was isolated not totally pure. $\delta_{\mathrm{H}}\left(300 \mathrm{MHz} ; \mathrm{CDCl}_{3}\right): 8.41(\mathrm{~d}, 1 \mathrm{H}, J=$ $7.5 \mathrm{~Hz}, \mathrm{H}-6), 8.06$ (dd, $\left.2 \mathrm{H}, J=9.6,1.2 \mathrm{~Hz}, \mathrm{ArH}_{\text {ortho }}\right), 7.92(\mathrm{~d}, 1 \mathrm{H}$, $J=7.5 \mathrm{~Hz}, \mathrm{H}-5), 7.80$ (dd, $\left.2 \mathrm{H}, J=8.4,1.5 \mathrm{~Hz}, \mathrm{ArH}_{\text {ortho }}\right), 7.72-$ 7.65 (m, 2H, $\left.\mathrm{ArH}_{\text {para }}\right), 7.64-7.44$ (m, 4H, $\left.\mathrm{ArH}_{\text {meta }}\right), 7.17$ (bs, $1 \mathrm{H}$, $\mathrm{NH}), 6.51\left(\mathrm{dd}, 1 \mathrm{H}, J=8.1,5.7 \mathrm{~Hz}, \mathrm{H}_{-1}^{\prime}\right), 5.53(\mathrm{bd}, 1 \mathrm{H}, J=6.3 \mathrm{~Hz}$, $\mathrm{H}-3^{\prime}$ ), 4.38 (fine d, $1 \mathrm{H}, J=1.8 \mathrm{~Hz}, \mathrm{H}-4^{\prime}$ ), 4.03 (fine d, $2 \mathrm{H}, J=2.1$ $\left.\mathrm{Hz}, \mathrm{H}-5^{\prime}\right), 2.94\left(\mathrm{ddd}, 1 \mathrm{H}, J=14.1,5.4,0.9 \mathrm{~Hz}\right.$, one of $\mathrm{H}-2^{\prime}$ ), 2.32-2.21 (m, 1H, one of $\left.\mathrm{H}-2^{\prime}\right), 0.94\left[\mathrm{~s}, 9 \mathrm{H}, \mathrm{SiC}\left(\mathrm{CH}_{3}\right)_{3}\right], 0.160(\mathrm{~s}$, $\left.3 \mathrm{H}, \mathrm{SiCH}_{3}\right), 0.157\left(\mathrm{~s}, 3 \mathrm{H}, \mathrm{SiCH}_{3}\right) . \delta_{\mathrm{c}}\left(75 \mathrm{MHz} ; \mathrm{CDCl}_{3}\right): 166.1(\mathrm{C}$, $\mathrm{NCOPh}), 162.2(\mathrm{C}, \mathrm{OCOPh}), 144.6(\mathrm{CH}, \mathrm{C}-6), 133.6(\mathrm{CH}), 133.2$ $(\mathrm{CH}), 131.9(\mathrm{C}), 129.7(\mathrm{CH}), 129.3(\mathrm{C}), 128.9(\mathrm{CH}), 128.5(\mathrm{CH})$, $127.6(\mathrm{CH}), 96.6(\mathrm{CH}, \mathrm{C}-5), 87.4,86.4\left(\mathrm{CH}, \mathrm{C}-1^{\prime}, \mathrm{C}^{\prime} 4^{\prime}\right), 76.1(\mathrm{CH}$, C-3'), $63.6\left(\mathrm{CH}_{2}, \mathrm{C}-5^{\prime}\right), 39.7\left(\mathrm{CH}_{2}, \mathrm{C}-2^{\prime}\right), 25.9\left[\mathrm{CH}_{3}, \mathrm{SiC}\left(\mathrm{CH}_{3}\right)_{3}\right]$, $18.3\left[\mathrm{C}, \mathrm{SiC}\left(\mathrm{CH}_{3}\right)_{3}\right],-5.4\left(\mathrm{CH}_{3}, \mathrm{SiCH}_{3}\right),-5.5\left(\mathrm{CH}_{3}, \mathrm{SiCH}_{3}\right) . \mathrm{C}-2$ and C-4 not detected. HRMS (ES+) $m / z$ calcd for $\mathrm{C}_{29} \mathrm{H}_{36} \mathrm{~N}_{3} \mathrm{O}_{6} \mathrm{Si}$ $[\mathrm{M}+\mathrm{H}]^{+}$550.2373, found 550.2365.

$5^{\prime}$-O-tert-Butyldimethylsilyl-2'-O,3'-O,6-N, $\mathrm{N}$-tetrabenzoyladenosine (37a). ${ }^{24}$ Treatment of $36 \mathbf{6}$ ( $\left.4.80 \mathrm{~g}, 12.6 \mathrm{mmol}\right)$, benzoyl chloride $(14.15 \mathrm{~g}, 11.7 \mathrm{~mL}, 101.0 \mathrm{mmol})$, triethylamine $(10.19 \mathrm{~g}, 14.0 \mathrm{~mL}$, $101.0 \mathrm{mmol})$ and dimethylaminopyridine $(1.20 \mathrm{~g}, 10.1 \mathrm{mmol})$ in $\mathrm{CH}_{2} \mathrm{Cl}_{2}(60 \mathrm{~mL})$ by procedure $\mathrm{B}$ (chromatography using $\mathrm{CH}_{2} \mathrm{Cl}_{2} /$ $\mathrm{MeOH}, 99: 1)$ afforded the title product $37 \mathbf{a}$ as a solid $(6.60 \mathrm{~g}, 66 \%)$. mp: $159-160^{\circ} \mathrm{C} . \delta_{\mathrm{H}}\left(300 \mathrm{MHz} ; \mathrm{CDCl}_{3}\right): 8.66(\mathrm{~s}, 1 \mathrm{H}, \mathrm{H}-2$ or $\mathrm{H}-8)$, $8.54\left(\mathrm{~s}, 1 \mathrm{H}, \mathrm{H}-2\right.$ or H-8), 8.02-7.85 (m, 8H, ArH $\left._{\text {ortho }}\right), 7.60-7.34$ $\left(\mathrm{m}, 12 \mathrm{H}, 4 \mathrm{ArH}_{\text {para }}, 8 \mathrm{ArH}_{\text {meta }}\right), 6.69\left(\mathrm{~d}, 1 \mathrm{H}, J=6.9 \mathrm{~Hz}, \mathrm{H}-\mathrm{l}^{\prime}\right), 6.08$ $\left(\mathrm{dd}, 1 \mathrm{H}, J=6.6,5.4 \mathrm{~Hz}, \mathrm{H}-2^{\prime}\right), 5.93(\mathrm{dd}, 1 \mathrm{H}, J=5.4,2.4 \mathrm{~Hz}$, H-3' $), 4.58-4.54\left(\mathrm{~m}, 1 \mathrm{H}, \mathrm{H}-4^{\prime}\right), 4.12-4.02\left(\mathrm{~m}, 2 \mathrm{H}, \mathrm{H}-5^{\prime}\right), 0.98[\mathrm{~s}$, $\left.9 \mathrm{H}, \mathrm{SiC}\left(\mathrm{CH}_{3}\right)_{3}\right], 0.20\left(\mathrm{~s}, 3 \mathrm{H}, \mathrm{SiCH}_{3}\right), 0.18\left(\mathrm{~s}, 3 \mathrm{H}, \mathrm{SiCH}_{3}\right) . \delta_{\mathrm{c}}(75$ $\left.\mathrm{MHz} ; \mathrm{CDCl}_{3}\right): 172.3(2 \times \mathrm{C}, \mathrm{NCOPh}), 165.6(\mathrm{C}, \mathrm{OCOPh}), 165.0$ (C, OCOPh), 153.3 (C, C-6), $152.4(\mathrm{CH}, \mathrm{C}-2), 151.9$ (C, C-4), 142.9 $(\mathrm{CH}, \mathrm{C}-8), 134.0(\mathrm{C}), 133.7(\mathrm{CH}), 133.7(\mathrm{CH}), 133.0(\mathrm{CH}), 129.9$ $(\mathrm{CH}), 129.8(\mathrm{CH}), 129.5(\mathrm{CH}), 128.9(\mathrm{C}), 128.8(\mathrm{CH}), 128.6(\mathrm{CH})$, $128.5(\mathrm{CH}), 128.5(\mathrm{C}), 127.6(\mathrm{C}, \mathrm{C}-5), 85.5\left(\mathrm{CH}, \mathrm{C}-1^{\prime}\right), 84.9(\mathrm{CH}$, C-4' $), 74.8\left(\mathrm{CH}, \mathrm{C}-2^{\prime}\right), 72.6\left(\mathrm{CH}, \mathrm{C}-3^{\prime}\right), 63.3\left(\mathrm{CH}_{2}, \mathrm{C}-5^{\prime}\right), 26.1$ $\left[\mathrm{CH}_{3}, \mathrm{SiC}\left(\mathrm{CH}_{3}\right)_{3}\right], 18.5\left[\mathrm{C}, \mathrm{SiC}\left(\mathrm{CH}_{3}\right)_{3}\right],-5.3\left(\mathrm{CH}_{3}, \mathrm{SiCH}_{3}\right)$. HRMS $(\mathrm{ES}+) m / z$ calcd for $\mathrm{C}_{44} \mathrm{H}_{44} \mathrm{~N}_{5} \mathrm{O}_{8} \mathrm{Si}[\mathrm{M}+\mathrm{H}]^{+}{ }^{7} 798.2959$, found 798.2964 .

$5^{\prime}$-O-tert-Butyldimethylsilyl-3' $-O, 6-N, N$-tribenzoyl-2' -deoxyadenosine (37b). ${ }^{24}$ Treatment of $\mathbf{3 6} \mathbf{b}(4.00 \mathrm{~g}, 10.94 \mathrm{mmol})$, benzoyl chloride $(9.23 \mathrm{~g}, 7.62 \mathrm{~mL}, 65.70 \mathrm{mmol})$, triethylamine $(6.64 \mathrm{~g}, 9.15$ $\mathrm{mL}, 65.70 \mathrm{mmol})$ and dimethylaminopyridine $(0.80 \mathrm{~g}, 6.57 \mathrm{mmol})$ in dichloromethane $(60 \mathrm{~mL})$ by procedure $\mathrm{B}$ (chromatography using hexane/EtOAc, 75:25 to 70:30) afforded the title product 37b 
as a white solid $(5.56 \mathrm{~g}, 75 \%)$. mp: $75-76{ }^{\circ} \mathrm{C} . \delta_{\mathrm{H}}(300 \mathrm{MHz}$; $\left.\mathrm{CDCl}_{3}\right): 8.66(\mathrm{~s}, 1 \mathrm{H}, \mathrm{H}-2$ or $\mathrm{H}-8), 8.43(\mathrm{~s}, 1 \mathrm{H}, \mathrm{H}-2$ or $\mathrm{H}-8), 8.08$ (dd, $2 \mathrm{H}, J=8.7,1.5 \mathrm{~Hz}, \mathrm{O}-\mathrm{Bz}, \mathrm{ArH}_{\text {ortho }}$ ), 7.87 (dd, $4 \mathrm{H}, J=8.7$, $\left.1.5 \mathrm{~Hz}, \mathrm{~N}-\mathrm{Bz}, \mathrm{ArH}_{\text {ortho }}\right), 7.64-7.33$ (m, 9H, $\left.3 \mathrm{ArH}_{\text {para }}, 6 \mathrm{ArH}_{\text {meta }}\right)$, $6.69\left(\mathrm{dd}, 1 \mathrm{H}, J=8.1,6.3 \mathrm{~Hz}, \mathrm{H}-1^{\prime}\right), 5.70-5.66\left(\mathrm{~m}, 1 \mathrm{H}, \mathrm{H}-3^{\prime}\right)$, 4.41-4.38 (X part of ABX, 1H, H-4'), 4.03 (A part of ABX, 1H, $J=11.1,2.7 \mathrm{~Hz}$, one of $\left.\mathrm{H}-5^{\prime}\right), 3.96(\mathrm{~B}$ part of ABX, $1 \mathrm{H}, J=11.1$, $3.0 \mathrm{~Hz}$, one of $\left.\mathrm{H}-5^{\prime}\right), 2.87-2.78\left(\mathrm{~m}, 2 \mathrm{H}, \mathrm{H}-2^{\prime}\right), 0.91[\mathrm{~s}, 9 \mathrm{H}$, $\left.\mathrm{SiC}\left(\mathrm{CH}_{3}\right)_{3}\right], 0.12\left(\mathrm{~s}, 3 \mathrm{H}, \mathrm{SiCH}_{3}\right), 0.11\left(\mathrm{~s}, 3 \mathrm{H}, \mathrm{SiCH}_{3}\right) . \delta \mathrm{c}(75$ $\left.\mathrm{MHz} ; \mathrm{CDCl}_{3}\right): 172.3(\mathrm{C}, \mathrm{NCOPh}), 166.0(\mathrm{C}, \mathrm{OCOPh}), 152.8(\mathrm{C}$, C-6), 152.2 (CH, C-2), 151.8 (C, C-4), 142.9 (CH, C-8), 134.1 (C), $133.6(\mathrm{CH}), 132.9(\mathrm{CH}), 129.7(\mathrm{CH}), 129.5(\mathrm{CH}), 129.4(\mathrm{C}), 128.7$ $(\mathrm{CH}), 128.6(\mathrm{CH}), 127.6(\mathrm{C}, \mathrm{C}-5), 86.1\left(\mathrm{CH}, \mathrm{C}-1^{\prime}\right), 84.5\left(\mathrm{CH}, \mathrm{C}-4^{\prime}\right)$, $76.0\left(\mathrm{CH}, \mathrm{C}-3^{\prime}\right), 63.7\left(\mathrm{CH}_{2}, \mathrm{C}-5^{\prime}\right), 39.1\left(\mathrm{CH}_{2}, \mathrm{C}-2^{\prime}\right), 26.0[\mathrm{CH} 3$, $\left.\mathrm{SiC}\left(\mathrm{CH}_{3}\right)_{3}\right], 18.4\left[\mathrm{C}, \mathrm{SiC}\left(\mathrm{CH}_{3}\right)_{3}\right],-5.3\left(\mathrm{CH}_{3}, \mathrm{SiCH}_{3}\right),-5.5\left(\mathrm{CH}_{3}\right.$, $\left.\mathrm{SiCH}_{3}\right)$. HRMS $\left(\mathrm{ES}^{+}\right) \mathrm{m} / z$ calcd for $\mathrm{C}_{37} \mathrm{H}_{40} \mathrm{~N}_{5} \mathrm{O}_{6} \mathrm{Si}[\mathrm{M}+\mathrm{H}]^{+}$ 678.2748, found 678.2762.

Procedure C. Deprotection of the TBDMS Group. 3- $\mathrm{N}, \mathbf{3}^{\prime}-\mathrm{O}$ Dibenzoylthymidine (26b). ${ }^{47}$ To a stirred solution of $\mathbf{2 5 b}(3.00 \mathrm{~g}$, $5.31 \mathrm{mmol})$ in THF $(24 \mathrm{~mL})$, was added aqueous trifluoroacetic acid $\left(6 \mathrm{~mL}, \mathrm{TFA} / \mathrm{H}_{2} \mathrm{O}, 1: 1\right)$ at $0^{\circ} \mathrm{C}$. After stirring for $3 \mathrm{~h}$ at room temperature, the reaction mixture was neutralized with saturated aqueous $\mathrm{NaHCO}_{3}(20 \mathrm{~mL})$ and diluted with ethyl acetate $(30 \mathrm{~mL})$. After separation the organic phase was washed with water $(2 \times 20 \mathrm{~mL})$, dried over magnesium sulfate, filtered and evaporated in vacuo. The crude product was purified by flash chromatography using $\mathrm{CH}_{2} \mathrm{Cl}_{2} / \mathrm{MeOH}$ (97:3) as eluent to afford the title product 26b as a white solid $(2.20 \mathrm{~g}, 92 \%)$. mp: $166-167$ ${ }^{\circ} \mathrm{C} . \delta_{\mathrm{H}}\left(300 \mathrm{MHz} ; \mathrm{CDCl}_{3}\right): 8.04-8.01(\mathrm{~d}, 2 \mathrm{H}, J=8.4,1.2 \mathrm{~Hz}$, $\left.\mathrm{ArH}_{\text {ortho }}\right), 7.96-7.93\left(\mathrm{~d}, 2 \mathrm{H}, J=8.7,1.5 \mathrm{~Hz}, \mathrm{ArH}_{\text {ortho }}\right), 7.72$ (finely split s, $1 \mathrm{H}, \mathrm{H}-6), 7.68-7.63\left(\mathrm{~m}, 1 \mathrm{H}, \mathrm{ArH}_{\text {para }}\right), 7.62-7.58$ $\left(\mathrm{m}, 1 \mathrm{H}, \mathrm{ArH}_{\text {para }}\right), 7.52-7.40\left(\mathrm{~m}, 4 \mathrm{H}, \mathrm{ArH}_{\text {meta }}\right), 6.40(\mathrm{dd}, 1 \mathrm{H}$, $\left.J=7.9,6.2 \mathrm{~Hz}, \mathrm{H}-1^{\prime}\right), 5.62-5.60\left(\mathrm{~m}, 1 \mathrm{H}, \mathrm{H}^{-} 3^{\prime}\right), 4.28-4.26(\mathrm{~m}, 1$ $\left.\mathrm{H}, \mathrm{H}-4^{\prime}\right), 4.04$ (br s, $\left.2 \mathrm{H}, 2 \times \mathrm{H}-5^{\prime}\right), 2.64-2.51\left(\mathrm{~m}, 2 \mathrm{H}, 2 \times \mathrm{H}-2^{\prime}\right)$, 2.27 (br s, $1 \mathrm{H}, \mathrm{OH}), 2.00$ (finely split s, $\left.3 \mathrm{H}, \mathrm{CH}_{3}\right) . \delta_{\mathrm{c}}(75 \mathrm{MHz}$; $\left.\mathrm{CDCl}_{3}\right): 169.3(\mathrm{C}, \mathrm{NCOPh}), 166.6(\mathrm{C}, \mathrm{OCOPh}), 163.2(\mathrm{C}, \mathrm{C}-4)$, 149.9 (C, C-2), $136.4(\mathrm{CH}, \mathrm{C}-6), 135.5(\mathrm{CH}), 134.1(\mathrm{CH}), 131.9$ (C), $130.9(\mathrm{CH}), 130.1(\mathrm{CH}), 130.0(\mathrm{CH}), 129.5(\mathrm{CH}), 129.0(\mathrm{C})$, $111.9(\mathrm{C}, \mathrm{C}-5), 86.2,85.7\left(2 \times \mathrm{CH}, \mathrm{C}-1^{\prime}, \mathrm{C}-4^{\prime}\right), 75.7\left(\mathrm{CH}, \mathrm{C}-3^{\prime}\right)$, $63.0\left(\mathrm{CH}_{2}, \mathrm{C}-5^{\prime}\right), 38.0\left(\mathrm{CH}_{2}, \mathrm{C}-2^{\prime}\right), 13.1\left(\mathrm{CH}_{3}, \mathrm{CH}_{3}-\mathrm{C}-5\right)$. HRMS $(\mathrm{ES}+) m / z$ calcd for $\mathrm{C}_{24} \mathrm{H}_{23} \mathrm{~N}_{2} \mathrm{O}_{7}[\mathrm{M}+\mathrm{H}]^{+} 451.15 .05$, found 451.1497.

$\mathbf{3}-\boldsymbol{N}, \mathbf{2}^{\prime}-\boldsymbol{O}, \mathbf{3}^{\prime}-\boldsymbol{O}$-Tribenzoyluridine $(\mathbf{3 0 a}){ }^{48}$ Treatment of $\mathbf{2 9 a}$ (900 mg, $1.34 \mathrm{mmol})$ in THF $(10 \mathrm{~mL})$ and aqueous TFA $(5 \mathrm{~mL}$, TFA $/ \mathrm{H}_{2} \mathrm{O}, 1: 1$ ) by procedure $\mathrm{C}$ (the residual solid was then stirred with hexanes, filtered and dried in vacuo) afforded the title compound 30a as a white solid (660 mg, 88\%). mp: 182-183 ${ }^{\circ} \mathrm{C}\left(\right.$ lit.. $\left.{ }^{45} 191-193^{\circ} \mathrm{C}\right) . \delta_{\mathrm{H}}\left(300 \mathrm{MHz} ; \mathrm{CDCl}_{3}\right): 8.08(\mathrm{~d}, 1 \mathrm{H}, J=$ 8.4 Hz, H-6), 8.03-7.83 (m, 6H, ArH ortho $_{1}$, 7.63-7.47 (m, 3H, $\left.\mathrm{ArH}_{\text {para }}\right), 7.45-7.26\left(\mathrm{~m}, 6 \mathrm{H}, \mathrm{ArH}_{\text {meta }}\right), 6.41(\mathrm{~d}, 1 \mathrm{H}, J=6.2 \mathrm{~Hz}$, $\left.\mathrm{H}-1^{\prime}\right), 5.92(\mathrm{~d}, 1 \mathrm{H}, J=8.1 \mathrm{~Hz}, \mathrm{H}-5), 5.88-5.78\left(\mathrm{~m}, 2 \mathrm{H}, \mathrm{H}-3^{\prime}\right.$, $\left.\mathrm{H}-2^{\prime}\right), 4.47-4.44$ (m, $\left.1 \mathrm{H}, \mathrm{H}-4^{\prime}\right), 4.04-3.93$ ( $\left.\mathrm{m}, 2 \mathrm{H}, 2 \times \mathrm{H}-5^{\prime}\right)$, 3.33 (br s, $1 \mathrm{H}, \mathrm{OH}) . \delta_{\mathrm{c}}\left(75 \mathrm{MHz} ; \mathrm{CDCl}_{3}\right): 168.5(\mathrm{C}, \mathrm{NCOPh})$, 165.7 (C, OCOPh), 165.5 (C, OCOPh), 162.1 (C, C-4), 149.7 (C, C-2), $140.5(\mathrm{CH}, \mathrm{C}-6), 135.1(\mathrm{CH}), 133.8(\mathrm{CH}), 133.7(\mathrm{CH})$, $131.3(\mathrm{C}), 130.5(\mathrm{CH}), 129.9(\mathrm{CH}), 129.8(\mathrm{CH}), 129.1(\mathrm{CH})$, $128.9(\mathrm{C}), 128.6(\mathrm{CH}), 128.5(\mathrm{CH}), 128.4(\mathrm{C}), 103.2(\mathrm{CH}, \mathrm{C}-5)$, $87.5\left(\mathrm{CH}, \mathrm{C}-1^{\prime}\right), 84.1\left(\mathrm{CH}, \mathrm{C}-4^{\prime}\right), 74.2\left(\mathrm{CH}, \mathrm{C}-2^{\prime}\right), 72.5(\mathrm{CH}$, C-3'), $62.0\left(\mathrm{CH}_{2}, \mathrm{C}-5^{\prime}\right)$. HRMS (ES+) $m / z$ calcd for $\mathrm{C}_{30} \mathrm{H}_{25^{-}}$ $\mathrm{N}_{2} \mathrm{O}_{9}[\mathrm{M}+\mathrm{H}]^{+}$557.1564, found 557.1560.

3- $\mathrm{N}, \mathbf{2}^{\prime}-\mathrm{O}, \mathbf{3}^{\prime}$-O $\mathrm{O}$-Tribenzoyl-5-methyluridine (26a). Treatment of 25a $(10.40 \mathrm{~g}, 15.20 \mathrm{mmol})$ in THF $(40 \mathrm{~mL})$ and aqueous TFA $\left(20 \mathrm{~mL}, \mathrm{TFA} / \mathrm{H}_{2} \mathrm{O}, 1: 1\right)$ by procedure $\mathrm{C}$ (chromatography using hexane/EtOAc, 50:50) afforded the title compound 26a as

(47) Zhu, X. F.; Williams, H. J.; Scott, A. I. J. Chem. Soc., Perkin Trans. 1 2000, 2305.

(48) Lohrmann, R.; Khorana, H. G. J. Am. Chem. Soc. 1964, 86, 4188. a white solid $(7.70 \mathrm{~g}, 89 \%)$. mp: $103-104{ }^{\circ} \mathrm{C} . \delta_{\mathrm{H}}(300 \mathrm{MHz}$; $\left.\mathrm{CDCl}_{3}\right): 8.00-7.88\left(\mathrm{~m}, 6 \mathrm{H}, \mathrm{ArH}_{\text {ortho}}\right), 7.70$ (finely split s, $1 \mathrm{H}$, $\mathrm{H}-6), 7.63-7.49$ (m, 3H, $\left.\mathrm{ArH}_{\text {para }}\right), 7.45-7.30$ (m, 6H, $\mathrm{ArH}_{\text {meta }}$ ), 6.36-6.29 (m, 1H, H-1'), 5.88-5.80 (m, 2H, H-2', H-3'), $4.48-4.43\left(\mathrm{~m}, 1 \mathrm{H}, \mathrm{H}-4^{\prime}\right), 4.10-3.99\left(\mathrm{~m}, 2 \mathrm{H}, \mathrm{H}-5^{\prime}\right), 2.60$ (bs, $1 \mathrm{H}, \mathrm{OH}), 2.00\left(\mathrm{~s}, 3 \mathrm{H}, \mathrm{CH}_{3}\right) . \delta_{\mathrm{c}}\left(75 \mathrm{MHz} ; \mathrm{CDCl}_{3}\right): 168.5(\mathrm{C}$, $\mathrm{NCOPh}), 165.6(\mathrm{C}, \mathrm{OCOPh}), 165.4(\mathrm{C}, \mathrm{OCOPh}), 162.5$ (C, C-4), 149.7 (C, C-2), 135.9 (CH, C-6), $134.9(\mathrm{CH}), 133.7$ (CH), 133.7 $(\mathrm{CH}), 131.5(\mathrm{C}), 130.5(\mathrm{CH}), 129.9(\mathrm{CH}), 129.8(\mathrm{CH}), 129.1$ $(\mathrm{CH}), 128.9(\mathrm{C}), 128.6(\mathrm{CH}), 128.5(\mathrm{CH}), 111.9(\mathrm{C}, \mathrm{C}-5), 84.8$ $\left(\mathrm{CH}, \mathrm{C}-1^{\prime}\right), 83.8\left(\mathrm{CH}, \mathrm{C}-4^{\prime}\right), 73.7\left(\mathrm{CH}, \mathrm{C}-3^{\prime}\right), 72.1\left(\mathrm{CH}, \mathrm{C}-2^{\prime}\right)$, $62.2\left(\mathrm{CH}_{2}, \mathrm{C}-5^{\prime}\right), 12.7\left(\mathrm{CH}_{3}, \mathrm{CH}_{3}-\mathrm{C}-5\right)$. HRMS (ES+) $\mathrm{m} / z$ calcd for $\mathrm{C}_{31} \mathrm{H}_{27} \mathrm{~N}_{2} \mathrm{O}_{9}[\mathrm{M}+\mathrm{H}]^{+}$571.1717, found 571.1708. $v_{\max }$ $\mathrm{cm}^{-1}$ (film) 3068, 1727, 1664, 1449, 1268, 1095, 712.

$\mathbf{3}^{\prime}$-O,3- $\mathrm{N}$-Dibenzoyl-2'-deoxyuridine (30b). Treatment of $29 \mathrm{~b}$ $(1.10 \mathrm{~g}, 2.00 \mathrm{mmol})$ in THF $(10 \mathrm{~mL})$ and aqueous TFA $(5 \mathrm{~mL}$, TFA $/ \mathrm{H}_{2} \mathrm{O}, 1: 1$ ) by procedure $\mathrm{C}$ (chromatography using $\mathrm{CH}_{2} \mathrm{Cl}_{2} / \mathrm{MeOH}$ 97:3) afforded the title product 30b as a white solid $(790 \mathrm{mg}, 91 \%)$. mp: $72-73{ }^{\circ} \mathrm{C}$. $\delta_{\mathrm{H}}\left(300 \mathrm{MHz} ; \mathrm{CDCl}_{3}\right)$ : 8.04-7.94 (m, 5H, H-6, ArH ortho $_{2}$, 7.69-7.57 (m, 2H, $\mathrm{ArH}_{\text {para }}$ ), 7.53-7.42 (m, 4H, ArH meta $), 6.40(\mathrm{dd}, 1 \mathrm{H}, J=8.1,5.7 \mathrm{~Hz}$, $\left.\mathrm{H}-1^{\prime}\right), 5.90(\mathrm{~d}, 1 \mathrm{H}, J=8.1 \mathrm{~Hz}, \mathrm{H}-5), 5.63-5.58\left(\mathrm{~m}, 1 \mathrm{H}, \mathrm{H}-3^{\prime}\right)$, $4.30-4.27$ (m, 1H, H-4 $), 4.05-4.02\left(\mathrm{~m}, 2 \mathrm{H}, \mathrm{H}-5^{\prime}\right), 2.66$ (ddd, $1 \mathrm{H}, J=14.1,6.0,2.4 \mathrm{~Hz}$, one $\left.\mathrm{H}-2^{\prime}\right), 2.50(\mathrm{ddd}, 1 \mathrm{H}, J=14.4,8.4$, $6.6 \mathrm{~Hz}$, one $\left.\mathrm{H}-2^{\prime}\right), 2.21$ (bs, $\left.1 \mathrm{H}, \mathrm{OH}\right) . \delta_{\mathrm{c}}\left(75 \mathrm{MHz} ; \mathrm{CDCl}_{3}\right): 168.6$ (C, NCOPh), 166.2 (C, OCOPh), 162.0 (C, C-4), 149.4 (C, C-2), $140.0(\mathrm{CH}, \mathrm{C}-6), 135.2(\mathrm{CH}), 133.7(\mathrm{CH}), 131.5(\mathrm{C}), 130.5(\mathrm{CH})$, $129.7(\mathrm{CH}), 129.2(\mathrm{CH}), 129.1(\mathrm{C}), 128.6(\mathrm{CH}), 102.9(\mathrm{CH}, \mathrm{C}-5)$, 86.1, 85.4 (2 $\left.\times \mathrm{CH}, \mathrm{C}-4^{\prime}, \mathrm{C}-1^{\prime}\right), 75.2\left(\mathrm{CH}, \mathrm{C}-3^{\prime}\right), 62.7\left(\mathrm{CH}_{2}, \mathrm{C}-5^{\prime}\right)$, $38.0\left(\mathrm{CH}_{2}, \mathrm{C}-2^{\prime}\right)$. HRMS (ES +$) m / z$ calcd for $\mathrm{C}_{23} \mathrm{H}_{21} \mathrm{~N}_{2} \mathrm{O}_{7}[\mathrm{M}+$ $\mathrm{H}]^{+}$437.1349, found 437.1341. $v_{\max } \mathrm{cm}^{-1}$ (film) 3494, 1748, 1705, 1667, 1450, 1271, 1098, 714.

$\mathbf{2}^{\prime}-\boldsymbol{O}, \mathbf{3}^{\prime}-\boldsymbol{O}, \mathbf{4}-\boldsymbol{N}$-Tribenzoylcytidine $(\mathbf{3 4 a}){ }^{49}$ Treatment of $\mathbf{3 3 a}$ $(8.75 \mathrm{~g}, 13.06 \mathrm{mmol})$ in THF $(20 \mathrm{~mL})$ and aqueous TFA $(10 \mathrm{~mL}$, TFA $/ \mathrm{H}_{2} \mathrm{O}, 1: 1$ ) by procedure $\mathrm{C}$ (chromatography using neat $\mathrm{CH}_{2} \mathrm{Cl}_{2}$ to $\mathrm{CH}_{2} \mathrm{Cl}_{2} / \mathrm{MeOH}, 98: 2$ ) afforded the title product 34a as a white solid $(3.82 \mathrm{~g}, 53 \%)$. mp: $185-186^{\circ} \mathrm{C}$ (lit.: ${ }^{46} 180-182$ $\left.{ }^{\circ} \mathrm{C}\right) . \delta_{\mathrm{H}}\left(300 \mathrm{MHz} ; \mathrm{CDCl}_{3}\right): 9.15(\mathrm{bs}, 1 \mathrm{H}, \mathrm{NH}), 8.54(\mathrm{~d}, 1 \mathrm{H}, J=$ $7.5 \mathrm{~Hz}, \mathrm{H}-6), 7.89-7.80$ (m, 6H, ArH $_{\text {ortho }}$ ), 7.63-7.62 (bd, 1H, $\mathrm{H}-5), 7.55-7.45$ (m, 3H, $\left.\mathrm{ArH}_{\text {para }}\right), 7.38-7.25$ (m, 6H, $\mathrm{ArH}_{\text {meta }}$ ), $6.54\left(\mathrm{~d}, 1 \mathrm{H}, J=5.4 \mathrm{~Hz}, \mathrm{H}-1^{\prime}\right), 6.04-5.94\left(\mathrm{~m}, 2 \mathrm{H}, \mathrm{H}-2^{\prime}, \mathrm{H}-3^{\prime}\right)$, 4.59 (bs, $1 \mathrm{H}, \mathrm{OH}), 4.51-4.48$ (m, 1H, H-4'), 4.09-3.97 (m, 2H, $\left.\mathrm{H}-5^{\prime}\right) . \delta_{\mathrm{c}}\left(75 \mathrm{MHz} ; \mathrm{CDCl}_{3}\right): 165.7(\mathrm{C}, \mathrm{NCOPh}), 165.3(\mathrm{C}, 2 \times$ OCOPh), 162.9 (C, C-4), 155.6 (C, br, C-2), 146.0 (CH, br, C-6), $133.6(\mathrm{CH}), 133.5(\mathrm{CH}), 133.2(\mathrm{C}), 133.0(\mathrm{CH}), 129.9(\mathrm{CH})$, $129.8(\mathrm{CH}), 128.9(\mathrm{C}), 128.8(\mathrm{CH}), 128.7(\mathrm{C}), 128.5(\mathrm{CH}), 128.4$ $(\mathrm{CH}), 127.8(\mathrm{CH}), 98.0(\mathrm{CH}, \mathrm{br}, \mathrm{C}-5), 89.2\left(\mathrm{CH}, \mathrm{C}-1^{\prime}\right), 84.6(\mathrm{CH}$, C-4' $), 75.2\left(\mathrm{CH}, \mathrm{C}-2^{\prime}\right), 72.2\left(\mathrm{CH}, \mathrm{C}-3^{\prime}\right), 61.5\left(\mathrm{CH}_{2}, \mathrm{C}-5^{\prime}\right)$. HRMS (ES+) $m / z$ calcd for $\mathrm{C}_{30} \mathrm{H}_{26} \mathrm{~N}_{3} \mathrm{O}_{8}[\mathrm{M}+\mathrm{H}]^{+}$556.1720, found 556.1707.

$\mathbf{3}^{\prime}$-O,4- $N$-Dibenzoyl-2'-deoxycytidine (34b). Treatment of 33b $(4.34 \mathrm{~g}, 7.90 \mathrm{mmol})$ in THF $(20 \mathrm{~mL})$ and aqueous TFA $(10 \mathrm{~mL}$, TFA $/ \mathrm{H}_{2} \mathrm{O}, 1: 1$ ) by procedure $\mathrm{C}$ (the residue was washed with hexanes and filtered) afforded the title product $\mathbf{3 4 b}$ as a white solid $(2.65 \mathrm{~g}, 77 \%)$. mp: $190-191{ }^{\circ} \mathrm{C}$. $\delta_{\mathrm{H}}\left(300 \mathrm{MHz} ; \mathrm{CDCl}_{3}+\right.$ $\left.10 \% \mathrm{CD}_{3} \mathrm{OD}\right): 8.51(\mathrm{~d}, 1 \mathrm{H}, J=7.5 \mathrm{~Hz}, \mathrm{H}-6), 8.06(\mathrm{dd}, 2 \mathrm{H}, J=$ 8.4, 1.5 Hz, $\left.\mathrm{ArH}_{\text {ortho }}\right), 7.98\left(\mathrm{dd}, 2 \mathrm{H}, J=8.7,1.5 \mathrm{~Hz}, \mathrm{ArH}_{\text {ortho }}\right)$, 7.68-7.44 (m, 7H, ArH para $\left., \mathrm{ArH}_{\text {meta }}, \mathrm{H}-5\right), 6.42(\mathrm{dd}, 1 \mathrm{H}, J=$ 7.8, 5.7 Hz, H-1' $), 5.64-5.57\left(\mathrm{~m}, 1 \mathrm{H}, \mathrm{H}-3^{\prime}\right), 4.40-4.35(\mathrm{~m}, 1 \mathrm{H}$, $\left.\mathrm{H}-4^{\prime}\right), 3.98-3.95\left(\mathrm{~m}, 2 \mathrm{H}, \mathrm{H}-5^{\prime}\right), 2.86(\mathrm{ddd}, 1 \mathrm{H}, J=14.4,6.0,2.1$ $\mathrm{Hz}$, one of $\left.\mathrm{H}-2^{\prime}\right), 2.49-2.37\left(\mathrm{~m}, 1 \mathrm{H}\right.$, one of $\left.\mathrm{H}-2^{\prime}\right) . \delta_{\mathrm{c}}(75 \mathrm{MHz}$; $\left.\mathrm{CDCl}_{3}+10 \% \mathrm{CD}_{3} \mathrm{OD}\right): 167.6(\mathrm{C}, \mathrm{NCOPh}), 166.4(\mathrm{C}, \mathrm{OCOPh})$, 163.2 (C, C-4), 156.2 (C, C-2), 145.1 (CH, C-6), $133.6(\mathrm{CH})$, $133.1(\mathrm{CH}), 133.0(\mathrm{C}), 129.7(\mathrm{CH}), 129.3(\mathrm{C}), 128.8(\mathrm{CH}), 128.5$ $(\mathrm{CH}), 127.9(\mathrm{CH}), 97.6(\mathrm{CH}, \mathrm{C}-5), 87.7,86.4\left(\mathrm{CH}, \mathrm{C}-1^{\prime}, \mathrm{C}-4^{\prime}\right)$, $75.8\left(\mathrm{CH}, \mathrm{C}-3^{\prime}\right), 61.9\left(\mathrm{CH}_{2}, \mathrm{C}-5^{\prime}\right), 39.2\left(\mathrm{CH}_{2}, \mathrm{C}-2^{\prime}\right)$. HRMS

(49) Cohen, S. B.; Halcomb, R. L. J. Org. Chem. 2000, 65, 6145. 
$\left(\mathrm{ES}+\right.$ ) $m / z$ calcd for $\mathrm{C}_{23} \mathrm{H}_{22} \mathrm{~N}_{3} \mathrm{O}_{6}[\mathrm{M}+\mathrm{H}]^{+} 436.1509$, found 436.1490 .

$\mathbf{2}^{\prime}-\mathrm{O}, \mathbf{3}^{\prime}-\mathrm{O}, \mathbf{6}-\mathrm{N}, \mathrm{N}$-Tetrabenzoyladenosine (38a). ${ }^{24}$ Treatment of $37 \mathbf{a}(2.40 \mathrm{~g}, 3.0 \mathrm{mmol})$ in THF $(20 \mathrm{~mL})$ and aqueous TFA $(10$ $\mathrm{mL}, \mathrm{TFA} / \mathrm{H}_{2} \mathrm{O}, 1: 1$ ) by procedure $\mathrm{C}$ (chromatography using $\left.\mathrm{CH}_{2} \mathrm{Cl}_{2} / \mathrm{MeOH}, 99: 1\right)$ afforded the title product 38a as a white solid $(1.80 \mathrm{~g}, 88 \%)$. mp: $194-195^{\circ} \mathrm{C} . \delta_{\mathrm{H}}\left(300 \mathrm{MHz} ; \mathrm{CDCl}_{3}\right)$ : 8.69 (s, 1H, H-2), 8.21 (s, 1H, H-8), 8.05-7.83 (m, 8H, ArH $_{\text {ortho }}$ ), $7.63-7.33\left(\mathrm{~m}, 12 \mathrm{H}, 4 \mathrm{ArH}_{\text {para }}, 8 \mathrm{ArH}_{\text {meta }}\right), 6.39-6.29(\mathrm{~m}, 2 \mathrm{H}$, H-1', $\left.\mathrm{H}-2^{\prime}\right), 6.05$ (dd, $\left.1 \mathrm{H}, J=4.8,1.2 \mathrm{~Hz}, \mathrm{H}-3^{\prime}\right), 5.49$ (dd, $1 \mathrm{H}$, $J=10.5,2.7 \mathrm{~Hz}, \mathrm{OH}), 4.61$ (fine d, $1 \mathrm{H}, J=2.1 \mathrm{~Hz}, \mathrm{H}-4^{\prime}$ ), 4.13$3.93\left(\mathrm{~m}, 2 \mathrm{H}, \mathrm{H}-5^{\prime}\right) . \delta_{\mathrm{c}}\left(75 \mathrm{MHz} ; \mathrm{CDCl}_{3}\right): 172.1(2 \times \mathrm{C}, \mathrm{NCOPh})$, 165.4 (C, OCOPh), 164.8 (C, OCOPh), 152.9 (C, C-6), 152.1 (C, C-4), 151.9 (CH, C-2), 144.2 (CH, C-8), $133.9(\mathrm{C}), 133.8(\mathrm{CH})$, $133.7(\mathrm{CH}), 133.1(\mathrm{CH}), 129.8(\mathrm{CH}), 129.7(\mathrm{CH}), 129.5(\mathrm{CH})$, $129.1(\mathrm{C}), 128.8(\mathrm{CH}), 128.6(\mathrm{C}), 128.5(\mathrm{CH}), 128.4(\mathrm{C}, \mathrm{C}-5), 89.0$ $\left(\mathrm{CH}, \mathrm{C}-1^{\prime}\right), 86.4\left(\mathrm{CH}, \mathrm{C}-4^{\prime}\right), 73.6\left(\mathrm{CH}, \mathrm{C}-2^{\prime}\right), 73.2\left(\mathrm{CH}, \mathrm{C}-3^{\prime}\right), 62.6$ $\left(\mathrm{CH}_{2}, \mathrm{C}-5^{\prime}\right)$. HRMS (ES+) $m / z$ calcd for $\mathrm{C}_{38} \mathrm{H}_{30} \mathrm{~N}_{5} \mathrm{O}_{8}[\mathrm{M}+\mathrm{H}]^{+}$ 684.2094, found 684.2079.

$\mathbf{3}^{\prime}-\mathbf{O}, \mathbf{6}-\mathrm{N}, \boldsymbol{N}$-Tribenzoyl-2' -deoxyadenosine $(\mathbf{3 8 b}) .^{24}$ Treatment of $37 \mathbf{b}(5.56 \mathrm{~g}, 8.20 \mathrm{mmol})$ in THF $(50 \mathrm{~mL})$ and aqueous TFA ( $\left.25 \mathrm{~mL}, \mathrm{TFA} / \mathrm{H}_{2} \mathrm{O}, 1: 1\right)$ by procedure $\mathrm{C}$ (chromatography using $\mathrm{CH}_{2} \mathrm{Cl}_{2} / \mathrm{MeOH}, 99: 1$ to $98: 2$ ) afforded the title product $\mathbf{3 8 b}$ as a white solid $(4.10 \mathrm{~g}, 89 \%)$. mp: $86-87^{\circ} \mathrm{C} . \delta_{\mathrm{H}}\left(300 \mathrm{MHz} ; \mathrm{CDCl}_{3}\right)$ : 8.67 (s, 1H, H-2 or H-8), 8.20 (s, 1H, H-2 or H-8), 8.08 (dd, $2 \mathrm{H}, J=$ 8.7, 1.5 Hz, O-Bz, ArHortho), 7.86 (dd, 4H, $J=8.7,1.5 \mathrm{~Hz}, \mathrm{~N}-\mathrm{Bz}$, ArHortho), 7.65-7.34 (m, 9H, 3ArHpara, 6ArHmeta), 6.46 (dd, $\left.1 \mathrm{H}, J=9.6,5.4 \mathrm{~Hz}, \mathrm{H}-1^{\prime}\right), 5.81\left(\mathrm{bd}, 1 \mathrm{H}, J=5.4 \mathrm{~Hz}, \mathrm{H}-3^{\prime}\right), 5.41$ (bdd, 1H, OH), 4.45 (bs, 1H, H-4'), 4.05-3.99 (m, 2H, H-5'), 3.27 (ddd, $1 \mathrm{H}, J=14.1,9.6,5.7 \mathrm{~Hz}$, one of $\left.\mathrm{H}-2^{\prime}\right), 2.64(\mathrm{dd}, 1 \mathrm{H}, J=$ $14.1,5.4 \mathrm{~Hz}$, one of $\left.\mathrm{H}_{-2}^{\prime}\right) . \delta \mathrm{c}\left(75 \mathrm{MHz} ; \mathrm{CDCl}_{3}\right)$ : $172.2(\mathrm{C}$, NCOAr), 165.9 (C, OCOAr), 152.8 (C, C-6), 151.9 (C, C-4), 151.7 (CH, C-2), 144.3 (CH, C-8), $133.9(\mathrm{C}), 133.6(\mathrm{CH}), 133.2$ $(\mathrm{CH}), 129.7(\mathrm{CH}), 129.5(\mathrm{CH}), 129.4(\mathrm{C}), 128.9(\mathrm{C}), 128.8(\mathrm{CH})$, $128.6(\mathrm{CH}), 87.7\left(\mathrm{CH}, \mathrm{C}-1^{\prime}\right.$ or $\left.\mathrm{C}-4^{\prime}\right), 87.4\left(\mathrm{CH}, \mathrm{C}-1^{\prime}\right.$ or $\left.\mathrm{C}-4^{\prime}\right), 76.7$ $\left(\mathrm{CH}, \mathrm{C}-3^{\prime}\right), 63.2\left(\mathrm{CH}_{2}, \mathrm{C}-5^{\prime}\right), 38.1\left(\mathrm{CH}_{2}, \mathrm{C}-2^{\prime}\right)$. HRMS (ES+) $m / z$ calcd for $\mathrm{C}_{31} \mathrm{H}_{26} \mathrm{~N}_{5} \mathrm{O}_{6}[\mathrm{M}+\mathrm{H}]^{+} 564.1883$, found 564.1874.

Procedure D: OH-Insertion Reaction. OH-Insertion Reaction of 3- $\mathrm{N}, 3^{\prime}$-O-Dibenzoyl Thymidine (26b) and Trimethyl Phosphonodiazoacetate (20) to Give Phosphonate 47b. 3- $N, 3^{\prime}-O$-Dibenzoylthymidine $\mathbf{2 6 b}(1.00 \mathrm{~g}, 2.20 \mathrm{mmol})$ and trimethyl phosphonodiazoacetate $\mathbf{2 0}(0.69 \mathrm{~g}, 3.33 \mathrm{mmol})$ were dissolved in benzene $(50 \mathrm{~mL})$ by heating under reflux. After complete dissolution of the product, the mixture was cooled down to room temperature before adding molecular sieves $(4 \AA, 1 \mathrm{~g}$, freshly activated at $\left.150{ }^{\circ} \mathrm{C}\right)$, then rhodium(II) acetate $(\sim 1 \mathrm{~mol} \%)$. The mixture was stirred overnight under reflux under nitrogen atmosphere. The mixture was then filtered through Celite, concentrated in vacuo and purified by flash chromatography by using neat $\mathrm{CH}_{2} \mathrm{Cl}_{2}$ to $\mathrm{CH}_{2} \mathrm{Cl}_{2} / \mathrm{MeOH}(99: 1)$ to afford the product $\mathbf{4 7 \mathbf { b }}$ as a colorless oil $(1.20 \mathrm{~g}, 86 \%)$. NMR shows roughly a $3: 2$ mixture of two epimers, most of the signals in ${ }^{1} \mathrm{H}$ NMR are overlapping, those which can be distinguished are highlighted. $\delta_{\mathrm{H}}\left(300 \mathrm{MHz} ; \mathrm{CDCl}_{3}\right)$ : 8.10 (finely split s, $0.6 \mathrm{H}, \mathrm{H}-6$ major epimer), $8.02-7.99(\mathrm{~m}, 2 \mathrm{H}$, $\mathrm{ArH}_{\text {ortho }}$ ), $7.96-7.93\left(\mathrm{~m}, 2 \mathrm{H}, \mathrm{ArH}_{\text {ortho }}\right.$ ), 7.90 (finely split s, $0.4 \mathrm{H}$, H-6 minor epimer), 7.66-7.54 (m, $\left.2 \mathrm{H}, \mathrm{ArH}_{\text {para }}\right), 7.51-7.40(\mathrm{~m}$, $4 \mathrm{H}, \mathrm{ArH}_{\text {meta }}$ ), 6.60-6.52 (m, 1H, H-1'), 5.75 (bs, 0.4H, H-3', minor epimer), 5.66 (bd, $0.6 \mathrm{H}, J=5.1 \mathrm{~Hz}, \mathrm{H}-3^{\prime}$, major epimer), $4.53(\mathrm{~d}, 0.4 \mathrm{H}, J=18.0 \mathrm{~Hz}, \mathrm{PCH}$ minor epimer), $4.48(\mathrm{~d}, 0.6 \mathrm{H}, J=$ $18.9 \mathrm{~Hz}, \mathrm{PCH}$ major epimer), 4.34 (bs, $0.6 \mathrm{H}, \mathrm{H}-4^{\prime}$, major epimer), 4.29 (bs, 0.4H, H-4', minor epimer), 4.14-3.85 (m, 11H, $2 \mathrm{H}-5^{\prime}$, carboxyl $\mathrm{CH}_{3} \mathrm{O}$ and phosphonate $\left.\mathrm{CH}_{3} \mathrm{O}\right), 2.60-2.48(\mathrm{~m}, 2 \mathrm{H}$, $\left.\mathrm{H}-2^{\prime}\right), 2.07\left(\mathrm{CH}_{3}, 1.2 \mathrm{H}\right.$, minor epimer $), 2.04\left(\mathrm{CH}_{3}, 1.8 \mathrm{H}\right.$, major epimer). $\delta_{\mathrm{C}}\left(75 \mathrm{MHz} ; \mathrm{CDCl}_{3}\right)$ : $169.1(\mathrm{C}$, major epimer, $\mathrm{NCOPh})$, 169.0 (C, minor epimer, NCOPh), $167.2(\mathrm{C}, \mathrm{d}, J=1.4 \mathrm{~Hz}$, minor epimer, $\left.\mathrm{CO}_{2} \mathrm{CH}_{3}\right), 166.9\left(\mathrm{C}, \mathrm{d}, J=1.7 \mathrm{~Hz}\right.$, major epimer, $\mathrm{CO}_{2^{-}}$ $\left.\mathrm{CH}_{3}\right), 166.1$ (C, major epimer, OCOAr), 166.0 (C, minor epimer, OCOAr), 163.0 (C, major epimer, C-4), 162.8 (C, minor epimer,
C-4), 149.7 (C, minor epimer, C-2), 149.6 (C, major epimer, C-2), 136.0 (CH, C-6 major epimer), 135.6 ( $\mathrm{CH}, \mathrm{C}-6$ minor epimer), $135.0(\mathrm{CH}$, minor epimer), $134.9(\mathrm{CH}$, major epimer $), 133.6(\mathrm{CH}$, major epimer), 133.5 (CH, minor epimer), 131.7 (C, major epimer), $131.6(\mathrm{C}$, minor epimer), $130.4(\mathrm{CH}), 129.6(\mathrm{CH}), 129.2(\mathrm{CH})$, $128.5(\mathrm{CH}), 112.0(\mathrm{C}$, minor epimer, $\mathrm{C}-5), 111.8(\mathrm{C}$, major epimer, C-5), $85.0\left(\mathrm{CH}\right.$, major epimer, $\left.\mathrm{C}-1^{\prime}\right), 84.5(\mathrm{CH}$, minor epimer, $\left.\mathrm{C}-1^{\prime}\right), 83.7\left(\mathrm{CH}\right.$, major epimer, $\left.\mathrm{C}-4^{\prime}\right), 83.6(\mathrm{CH}$, minor epimer, C-4'), $76.0(\mathrm{CH}, \mathrm{d}, J=196.5 \mathrm{~Hz}, \mathrm{PCH}$, minor epimer $), 76.3(\mathrm{CH}$, C-3', minor epimer), $76.0\left(\mathrm{CH}, \mathrm{C}-3^{\prime}\right.$, major epimer), $75.5(\mathrm{CH}, \mathrm{d}$, $J=201.0 \mathrm{~Hz}, \mathrm{PCH}$, major epimer $), 72.7\left(\mathrm{CH}_{2}, \mathrm{~d}, J=11.2 \mathrm{~Hz}\right.$, C-5', major epimer), $72.3\left(\mathrm{CH}_{2}, \mathrm{~d}, J=10.5 \mathrm{~Hz}, \mathrm{C}-5^{\prime}\right.$, minor epimer), 54.1-53.8 $\left(\mathrm{CH}_{3}, \mathrm{~m}, \mathrm{CH}_{3} \mathrm{O}-\mathrm{P}\right), 53.0\left(\mathrm{CH}_{3}, \mathrm{CO}_{2} \mathrm{CH}_{3}\right)$, $37.5\left(\mathrm{CH}_{2}, \mathrm{C}-2^{\prime}\right.$, major epimer $), 37.1\left(\mathrm{CH}_{2}, \mathrm{C}-2^{\prime}\right.$, minor epimer, $)$, $12.0\left(\mathrm{CH}_{3}, \mathrm{CH}_{3}-\mathrm{C}-5\right.$, minor epimer, $), 11.9\left(\mathrm{CH}_{3}, \mathrm{CH}_{3}-\mathrm{C}-5\right.$, major epimer). $\delta_{\mathrm{P}}\left(121 \mathrm{MHz} ; \mathrm{CDCl}_{3}\right): 16.5$ (major epimer), 16.4 (minor epimer). HRMS (ES + ) $m / z$ calcd for $\mathrm{C}_{29} \mathrm{H}_{32} \mathrm{~N}_{2} \mathrm{O}_{12} \mathrm{P}[\mathrm{M}+$ $\mathrm{H}]^{+}$631.1693, found 631.1677. $[\alpha]_{\mathrm{D}}-21.8\left(\mathrm{c} 1, \mathrm{CHCl}_{3}, 20^{\circ} \mathrm{C}\right)$.

$\mathrm{OH}$-Insertion Reaction of $3-\mathrm{N}, \mathbf{2}^{\prime}-\mathrm{O}, 3^{\prime}$-O -Tribenzoyluridine (30a) and Trimethyl Phosphonodiazoacetate (20) to Give Phosphonate 48a. Treatment of $30 \mathrm{a}(2.38 \mathrm{~g}, 4.30 \mathrm{mmol})$ and $\mathbf{2 0}(1.33 \mathrm{~g}$, $6.41 \mathrm{mmol})$ with rhodium(II) acetate $(\sim 1 \mathrm{~mol} \%)$ by procedure D (chromatography using EtOAc/hexane, 80:20 to neat EtOAc) afforded the title product $48 \mathrm{a}$ as a white solid $(2.27 \mathrm{~g}, 72 \%)$. NMR shows roughly a 0.55:0.45 mixture of two epimers. $\delta_{\mathrm{H}}(400$ $\mathrm{MHz} ; \mathrm{CDCl}_{3}$ ): 8.53 (d, $0.5 \mathrm{H}, J=8.4 \mathrm{~Hz}, \mathrm{H}-6$ one epimer), 8.33 (d, $0.5 \mathrm{H}, J=8.1 \mathrm{~Hz}, \mathrm{H}-6$ one epimer), $8.03-7.86\left(\mathrm{~m}, 6 \mathrm{H}, \mathrm{ArH}_{\text {ortho }}\right)$, $7.59-7.23\left(\mathrm{~m}, 9 \mathrm{H}, 3 \mathrm{ArH}_{\text {para, }}, 6 \mathrm{ArH}_{\text {meta }}\right), 6.66-6.59\left(\mathrm{~m}, 1 \mathrm{H}, \mathrm{H}-\mathrm{1}^{\prime}\right)$, 6.08-6.00 (m, 1H, H-5), 5.94-5.75 (m, 2H, H-2' $\left.\mathrm{H}^{\prime} 3^{\prime}\right), 4.60-4.52$ $\left(\mathrm{m}, 2 \mathrm{H}, \mathrm{PCH}, \mathrm{H}-4^{\prime}\right), 4.04-3.83\left(\mathrm{~m}, 11 \mathrm{H}, \mathrm{H}-5^{\prime}\right.$, carboxyl $\mathrm{CH}_{3} \mathrm{O}$ and phosphonate $\left.\mathrm{CH}_{3} \mathrm{O}\right) . \delta_{\mathrm{C}}\left(100 \mathrm{MHz} ; \mathrm{CDCl}_{3}\right)$ : $168.6,168.5(\mathrm{C}$, $\mathrm{NCOPh}, 2$ epimers), 167.0 (C, $\mathrm{CO}_{2} \mathrm{Me}, 2$ epimers), 165.5 (C, one of the OCOPh), 165.3 (C, one of the OCOPh, major epimer), 165.2 (C, one of the OCOPh, minor epimer), 162.0 (C, C-4, minor epimer), 161.9 (C, C-4, major epimer), 149.9 (C, C-2, major epimer), 149.8 (C, C-2, minor epimer), 140.7 ( $\mathrm{CH}$, C-6 minor epimer), 140.5 (CH, C-6 major epimer), $134.9(\mathrm{CH}), 133.7(\mathrm{CH})$, $133.6(\mathrm{CH}), 131.5(\mathrm{C}), 131.4(\mathrm{C}$, major epimer $), 130.4(\mathrm{CH}), 129.8$ $(\mathrm{CH}), 129.7(\mathrm{CH}), 129.0(\mathrm{CH}), 128.9(\mathrm{C}), 128.8(\mathrm{C}), 128.6(\mathrm{CH})$, $128.4(\mathrm{CH}), 103.6(\mathrm{CH}, \mathrm{C}-5$, major epimer), $103.3(\mathrm{CH}, \mathrm{C}-5$, minor epimer), 86.0 ( $\mathrm{CH}, \mathrm{C}-1^{\prime}$, minor epimer), 85.7 ( $\mathrm{CH}, \mathrm{C}-1^{\prime}$, major epimer), 82.8 ( $\mathrm{CH}, \mathrm{C}-4^{\prime}$, minor epimer), 82.7 ( $\mathrm{CH}, \mathrm{C}-4^{\prime}$, major epimer), $75.8(\mathrm{CH}, \mathrm{d}, J=157.0 \mathrm{~Hz}, \mathrm{PCH}$, one epimer), $75.7(\mathrm{CH}$, $\mathrm{d}, J=156.9 \mathrm{~Hz}, \mathrm{PCH}$, one epimer $), 74.1\left(\mathrm{CH}, \mathrm{C}-2^{\prime}\right.$ or $\mathrm{C}-3^{\prime}$, major epimer), 73.7 (CH, C-2' or C-3', minor epimer), $73.2\left(\mathrm{CH}, \mathrm{C}-2^{\prime}\right.$ or C-3'), $71.9\left(\mathrm{CH}_{2}, \mathrm{~d}, J=10.3 \mathrm{~Hz}, \mathrm{C}-5^{\prime}\right.$, minor epimer $), 71.7\left(\mathrm{CH}_{2}\right.$, $\mathrm{d}, J=12.1 \mathrm{~Hz}, \mathrm{C}-5^{\prime}$, major epimer $), 54.4-53.8\left(\mathrm{CH}_{3}, \mathrm{~m}, \mathrm{CH}_{3} \mathrm{O}-\right.$ P), 53.2, $53.17\left(\mathrm{CH}_{3}, \mathrm{CO}_{2} \mathrm{CH}_{3}\right) . \delta_{\mathrm{P}}\left(121 \mathrm{MHz} ; \mathrm{CDCl}_{3}\right): 16.31$ (major epimer), 16.16 (minor epimer). HRMS (ES + ) $\mathrm{m} / z$ calcd for $\mathrm{C}_{35} \mathrm{H}_{34} \mathrm{~N}_{2} \mathrm{O}_{14} \mathrm{P}[\mathrm{M}+\mathrm{H}]^{+}$737.1732, found 737.1748. $[\alpha]_{\mathrm{D}}-90.6$ (c $1, \mathrm{CHCl}_{3}, 20^{\circ} \mathrm{C}$ ).

$\mathrm{OH}-$ Insertion Reaction of 3- $\mathrm{N}, 2^{\prime}-\mathrm{O}, 3^{\prime}-\mathrm{O}$-Tribenzoyl-5-methyluridine (26a) and Trimethyl Phosphonodiazoacetate (20) to Give Phosphonate 47a. Treatment of 26a (2.00 g, $3.51 \mathrm{mmol})$ and 20 $(0.95 \mathrm{~g}, 4.56 \mathrm{mmol})$ with rhodium(II) acetate $(\sim 1 \mathrm{~mol} \%)$ by procedure D (chromatography using EtOAc/hexane, 80:20 to neat EtOAc) afforded the title product $47 \mathbf{a}$ as a white solid (1.61 g, $61 \%$ ). mp: $94-95^{\circ} \mathrm{C}$. NMR shows roughly a 1.2:1 mixture of two epimers. $\delta_{\mathrm{H}}\left(400 \mathrm{MHz} ; \mathrm{CDCl}_{3}\right): 8.14-8.13$ (finely split s, $0.55 \mathrm{H}, \mathrm{H}-6$, major epimer), $8.00-7.85\left(\mathrm{~m}, 6.45 \mathrm{H}, \mathrm{ArH}_{\text {ortho }}, \mathrm{H}-6\right.$ minor epimer), 7.59-7.46 (m, 3H, $\left.\mathrm{ArH}_{\text {para }}\right), 7.42-7.28(\mathrm{~m}, 6 \mathrm{H}$, $\left.\mathrm{ArH}_{\text {meta }}\right), 6.68\left(\mathrm{~d}, 0.55 \mathrm{H}, J=8.1 \mathrm{~Hz}, \mathrm{H}-1^{\prime}\right.$, major epimer), 6.63 $\left(\mathrm{d}, 0.45 \mathrm{H}, J=8.1 \mathrm{~Hz}, \mathrm{H}^{-1}{ }^{\prime}\right.$, minor epimer), $6.01(\mathrm{dd}, 0.45 \mathrm{H}, J=$ 5.7, $1.2 \mathrm{~Hz}, \mathrm{H}-3^{\prime}$, minor epimer), 5.89 (d, $0.55 \mathrm{H}, J=5.4 \mathrm{~Hz}$, $\mathrm{H}-3^{\prime}$, major epimer), 5.80-5.69 (m, $\left.1 \mathrm{H}, \mathrm{H}-2^{\prime}\right), 4.56(\mathrm{~d}, 0.45 \mathrm{H}$, $\mathrm{J}_{\mathrm{PCH}}=18.0 \mathrm{~Hz}, \mathrm{PCH}$, minor epimer $), 4.54-4.48(\mathrm{~m}, 1.55 \mathrm{H}$, $\mathrm{J}_{\mathrm{PCH}}=18.6 \mathrm{~Hz}, \mathrm{PCH}$ major epimer, $\left.\mathrm{H}-4^{\prime}\right), 4.13-3.85(\mathrm{~m}, 11 \mathrm{H}$, $\left.\mathrm{H}-5^{\prime}, 9 \mathrm{CH}_{3}\right), 2.11$ (d, $1.35 \mathrm{H}, J=1.2 \mathrm{~Hz}, \mathrm{CH}_{3}$, minor epimer), 
$2.06\left(\mathrm{~d}, 1.65 \mathrm{H}, J=1.2 \mathrm{~Hz}, \mathrm{CH}_{3}\right.$, major epimer $) . \delta_{\mathrm{c}}(100 \mathrm{MHz}$; $\left.\mathrm{CDCl}_{3}\right)$ : $168.7\left(\mathrm{C}, \mathrm{CO}_{2} \mathrm{Me}\right.$, major epimer $), 168.6\left(\mathrm{C}, \mathrm{CO}_{2} \mathrm{Me}\right.$, minor epimer), 167.1 (C, NCOPh, minor epimer), 166.9 (C, NCOPh, major epimer), 165.6 (C, OCOPh, 2 epimers), 165.3 (C, OCOPh, 2 epimers), 162.8 (C, C-4, major epimer), 162.7 (C, C-4, minor epimer), 150.0 (C, C-2, 2 epimers), 135.6 ( $\mathrm{CH}, \mathrm{C}-6$, major epimer), 135.2 ( $\mathrm{CH}, \mathrm{C}-6$, minor epimer), 134.7 ( $\mathrm{CH}, 2$ epimers), 133.7 ( $\mathrm{CH}, 2$ epimers), 133.6 (CH, 2 epimers), 131.6 (C, 2 epimers), 130.4 ( $\mathrm{CH}, 2$ epimers), 129.9 ( $\mathrm{CH}, 2$ epimers), $129.8(\mathrm{CH}$, 2 epimers), 129.0 ( $\mathrm{CH}, 2$ epimers), 128.9 (C, 2 epimers), 128.6 (CH, 2 epimers), 128.5 (CH, 2 epimers), 112.6 (C, C-5, minor epimer), 112.4 (C, C-5, major epimer), 85.4 ( $\mathrm{CH}, \mathrm{C}-1^{\prime}$, major epimer), 85.0 ( $\mathrm{CH}, \mathrm{C}-1^{\prime}$, minor epimer), 82.6 ( $\mathrm{CH}, \mathrm{C}-4^{\prime}$, major epimer), 82.4 (CH, C-4', minor epimer), 76.4(CH, d, $J=156.5 \mathrm{~Hz}$, $\mathrm{PCH}$, minor epimer), $75.9(\mathrm{CH}, \mathrm{d}, J=157.8 \mathrm{~Hz}, \mathrm{PCH}$, major epimer), 73.6, 73.1 ( $2 \times \mathrm{CH}, \mathrm{C}-2^{\prime}, \mathrm{C}-3^{\prime}$, major epimer $), 72.9,72.7$ $\left(2 \times \mathrm{CH}, \mathrm{C}-2^{\prime}, \mathrm{C}-3^{\prime}\right.$, minor epimer), $72.1\left(\mathrm{CH}_{2}, \mathrm{~d}, J=12.0 \mathrm{~Hz}\right.$, C-5', major epimer), $71.7\left(\mathrm{CH}_{2}, \mathrm{~d}, J=12.0 \mathrm{~Hz}, \mathrm{C}-5^{\prime}\right.$, minor epimer $), 54.5-53.9\left(\mathrm{CH}_{3}, \mathrm{~m},\left(\mathrm{CH}_{3} \mathrm{O}\right)_{2} \mathrm{PO}, 2\right.$ epimers $), 53.23\left(\mathrm{CH}_{3}\right.$, $\mathrm{CO}_{2} \mathrm{CH}_{3}$, minor epimer), $53.17\left(\mathrm{CH}_{3}, \mathrm{CO}_{2} \mathrm{CH}_{3}\right.$, major epimer), 12.1 $\left(\mathrm{CH}_{3}, \mathrm{CH}_{3}-\mathrm{C}-5\right.$, minor epimer $), 12.0\left(\mathrm{CH}_{3}, \mathrm{CH}_{3}-\mathrm{C}-5\right.$, major epimer). One aromatic $\mathrm{C}$ not seen. $\delta_{\mathrm{P}}\left(121 \mathrm{MHz} ; \mathrm{CDCl}_{3}\right): 16.12$ (minor epimer), 16.07 (major epimer). HRMS (ES + ) $m / z$ calcd for $\mathrm{C}_{36} \mathrm{H}_{35} \mathrm{~N}_{2} \mathrm{O}_{14} \mathrm{P}[\mathrm{M}+\mathrm{H}]^{+} 751.1904$, found 751.1876. $[\alpha]_{\mathrm{D}}-104.6$ (c $1, \mathrm{CHCl}_{3}, 20^{\circ} \mathrm{C}$ ). $v_{\max } \mathrm{cm}^{-1}$ (film) $2958,1732,1665,1600,1449$, 1374, 1267, 1125, 1046, 714 .

OH-Insertion Reaction of 3- $N, 3^{\prime}$-O-Dibenzoyl-2'deoxyuridine (30b) and Trimethyl Phosphonodiazoacetate (20) to Give Phosphonate 48b. Treatment of $\mathbf{3 0 b}(780 \mathrm{mg}, 1.79 \mathrm{mmol})$ and 20 (484 mg, $2.32 \mathrm{mmol}$ ) with rhodium(II) acetate ( $\sim 1 \mathrm{~mol} \%$ ) by procedure D (chromatography using $\mathrm{CH}_{2} \mathrm{Cl}_{2} / \mathrm{MeOH}, 99: 1$ ) afforded the title product $\mathbf{4 8 b}$ as a white solid (860 mg, 78\%). mp: $51-52{ }^{\circ} \mathrm{C}$. NMR shows roughly a $1: 1$ mixture of two epimers. $\delta_{\mathrm{H}}$ (300 MHz; $\left.\mathrm{CDCl}_{3}\right): 8.44$ (d, $0.5 \mathrm{H}, J=8.4 \mathrm{~Hz}, \mathrm{H}-6$, one epimer), 8.25 (d, 0.5H, $J=8.1 \mathrm{~Hz}, \mathrm{H}-6$, one epimer), 8.02-7.94 (m, 4H, $\left.\mathrm{ArH}_{\text {ortho }}\right), 7.67-7.55\left(\mathrm{~m}, 2 \mathrm{H}, \mathrm{ArH}_{\text {para }}\right), 7.52-7.41(\mathrm{~m}, 4 \mathrm{H}$, $\left.\mathrm{ArH}_{\text {meta }}\right), 6.59-6.52\left(\mathrm{~m}, 1 \mathrm{H}, \mathrm{H}-1^{\prime}\right), 5.98(\mathrm{~d}, 0.5 \mathrm{H}, J=8.1 \mathrm{~Hz}$, $\mathrm{H}-5$, one epimer), 5.95 (d, $0.5 \mathrm{H}, J=8.1 \mathrm{~Hz}, \mathrm{H}-5$, one epimer), $5.80-5.76\left(\mathrm{~m}, 0.5 \mathrm{H}, \mathrm{H}-3^{\prime}\right.$, one epimer), $5.68-5.64\left(\mathrm{~m}, 0.5 \mathrm{H}, \mathrm{H}-3^{\prime}\right.$, one epimer), 4.47 (d, $0.5 \mathrm{H}, J=18.6 \mathrm{~Hz}, \mathrm{PCH}$, one epimer), 4.46 (d, $0.5 \mathrm{H}, J=18.3 \mathrm{~Hz}, \mathrm{PCH}$, one epimer), $4.37-4.31\left(\mathrm{~m}, 1 \mathrm{H}, \mathrm{H}-4^{\prime}\right)$, $4.04-3.79\left(\mathrm{~m}, 11 \mathrm{H}, 2 \mathrm{H}-5^{\prime}, 9 \mathrm{CH}_{3}\right), 2.68-2.44\left(\mathrm{~m}, 2 \mathrm{H}, \mathrm{H}-2^{\prime}\right) . \delta_{\mathrm{c}}(75$ $\left.\mathrm{MHz} ; \mathrm{CDCl}_{3}\right): 168.9\left(\mathrm{C}, \mathrm{CO}_{2} \mathrm{Me}\right.$, one epimer $), 168.8\left(\mathrm{C}, \mathrm{CO}_{2} \mathrm{Me}\right.$, one epimer), 167.0 (C, NCOPh, 2 epimers), 166.0 (C, OCOPh, 2 epimers), 162.2 (C, C-4, one epimer), 162.1 (C, C-4, one epimer), 149.6 (C, C-2, 2 epimers), 141.0 (CH, C-6, one epimer), 140.7 (CH, C-6, one epimer), 135.0 ( $\mathrm{CH}, 2$ epimers), 133.6 ( $\mathrm{CH}, 2$ epimers), 131.6 (C, 2 epimers), 130.4 ( $\mathrm{CH}, 2$ epimers), 129.7 ( $\mathrm{CH}, 2$ epimers), 129.2 (C, 2 epimers), 129.1 ( $\mathrm{CH}, 2$ epimers), 128.5 (CH, 2 epimers), 103.2 (CH, C-5, one epimer), 102.8 (CH, C-5, one epimer), 85.5 $\left(\mathrm{CH}, \mathrm{C}-1^{\prime}\right.$, one epimer), 85.1 (CH, C-1', one epimer), $84.1(\mathrm{CH}$, $\mathrm{C}-4^{\prime}$, one epimer), $84.0\left(\mathrm{CH}, \mathrm{C}-4^{\prime}\right.$, one epimer $), 76.3\left(\mathrm{CH}, \mathrm{C}-3^{\prime}\right.$, one epimer), $76.2\left(\mathrm{CH}, \mathrm{C}-3^{\prime}\right.$, one epimer), $75.9(\mathrm{CH}, \mathrm{d}, J=158.0 \mathrm{~Hz}$, $\mathrm{PCH}$, one epimer), 75.8 (CH, d, $J=158.0 \mathrm{~Hz}, \mathrm{PCH}$, one epimer), $72.6\left(\mathrm{CH}_{2}, \mathrm{~d}, J=10.5 \mathrm{~Hz}, \mathrm{C}-5^{\prime}\right.$, one epimer $), 72.4\left(\mathrm{CH}_{2}, \mathrm{~d}, J=\right.$ $11.5 \mathrm{~Hz}, \mathrm{C}-5^{\prime}$, one epimer), 54.0-53.8 $\left(\mathrm{CH}_{3}, \mathrm{~m},\left(\mathrm{CH}_{3} \mathrm{O}\right)_{2} \mathrm{PO}\right.$, 2 epimers), $53.1\left(\mathrm{CH}_{3}, \mathrm{CO}_{2} \mathrm{CH}_{3}, 2\right.$ epimers $), 38.0\left(\mathrm{CH}_{2}, \mathrm{C}-2^{\prime}\right.$, one epimer), $37.7\left(\mathrm{CH}_{2}, \mathrm{C}-2^{\prime}\right.$, one epimer $) . \delta_{\mathrm{P}}\left(121 \mathrm{MHz} ; \mathrm{CDCl}_{3}\right)$ : 16.52 (one epimer), 16.50 (one epimer). HRMS (ES+) $\mathrm{m} / z$ calcd for $\mathrm{C}_{28} \mathrm{H}_{30} \mathrm{~N}_{2} \mathrm{O}_{12} \mathrm{P}[\mathrm{M}+\mathrm{H}]^{+}$617.1536, found 617.1525. $[\alpha]_{\mathrm{D}}-16.69$ (c $0.8, \mathrm{CHCl}_{3}, 20^{\circ} \mathrm{C}$ ). $v_{\max } \mathrm{cm}^{-1}$ (film) $1749,1707,1669,1450,1271$, 1028,716 .

$\mathrm{OH}$-Insertion Reaction of $2^{\prime}-O, 3^{\prime}-O, 4-N$-Tribenzoylcytidine 34a and Trimethyl Phosphonodiazoacetate 20 to Give Phosphonate 49a. Treatment of 34a (3.50 g, $6.30 \mathrm{mmol})$ and $20(1.57 \mathrm{~g}$, $7.56 \mathrm{mmol})$ with rhodium(II) acetate $(\sim 1 \mathrm{~mol} \%)$ by procedure D (chromatography using EtOAc/hexane, 80:20 to neat EtOAc) afforded the product 49 a as a solid (2.40 g, 52\%). NMR shows roughly a $1: 1$ mixture of two epimers. $\delta_{\mathrm{H}}\left(300 \mathrm{MHz} ; \mathrm{CDCl}_{3}\right)$ : 9.15 (bs, $1 \mathrm{H}, \mathrm{NH}), 8.82$ (d, $0.5 \mathrm{H}, J=7.8 \mathrm{~Hz}, \mathrm{H}-6,1$ epimer), 8.61 (d, $0.5 \mathrm{H}, J=7.8 \mathrm{~Hz}, \mathrm{H}-6,1$ epimer), $8.00-7.88$ (m, 6H, $\mathrm{ArH}_{\text {ortho }}$ ), $7.59-7.30$ (m, 10H, H-5, $\left.\mathrm{ArH}_{\text {para }}, \mathrm{ArH}_{\text {meta }}\right), 6.84$ (d, 0.5H, $J=6.6$ $\mathrm{Hz}, \mathrm{H}-1^{\prime}, 1$ epimer), 6.83 (d, $0.5 \mathrm{H}, J=6.6 \mathrm{~Hz}, \mathrm{H}-1^{\prime}, 1$ epimer), 6.02 (dd, $0.5 \mathrm{H}, J=5.4,2.4 \mathrm{~Hz}, \mathrm{H}-3^{\prime}, 1$ epimer), 5.92 (dd, $0.5 \mathrm{H}, J=5.4$, $2.4 \mathrm{~Hz}, \mathrm{H}-3^{\prime}, 1$ epimer), 5.83 (dd, $0.5 \mathrm{H}, J=6.6,5.7 \mathrm{~Hz}, \mathrm{H}-2^{\prime}$, 1 epimer), 5.76 (dd, $0.5 \mathrm{H}, J=6.6,5.7 \mathrm{~Hz}, \mathrm{H}-2^{\prime}, 1$ epimer), 4.65 (d, $0.5 \mathrm{H}, J=18.6 \mathrm{~Hz}, \mathrm{PCH}, 1$ epimer $), 4.63(\mathrm{~d}, 0.5 \mathrm{H}, J=18.6 \mathrm{~Hz}$, $\mathrm{PCH}, 1$ epimer), $4.57-4.53\left(\mathrm{~m}, 1 \mathrm{H}, \mathrm{H}-4^{\prime}\right), 4.03-3.83(\mathrm{~m}, 11 \mathrm{H}, 2 \mathrm{H}-$ $\left.5^{\prime}, 9 \mathrm{CH}_{3}\right) \cdot \delta_{\mathrm{c}}\left(75 \mathrm{MHz} ; \mathrm{CDCl}_{3}\right): 167.0(\mathrm{C}, \mathrm{NCOPh}, 2$ epimers), 165.5 (C, $2 \times \mathrm{OCOPh}, 1$ epimer), 165.1 (C, $2 \times \mathrm{OCOPh}, 1$ epimer), 162.6 (C, C-4, 2 epimers), 145.8 (CH, C-6, 1 epimer), $145.6(\mathrm{CH}$, C-6, 1 epimer), $133.6(\mathrm{CH}), 133.5(\mathrm{CH}), 133.2(\mathrm{C}), 133.0(\mathrm{CH})$, $130.0(\mathrm{CH}), 129.8(\mathrm{CH}), 128.9(\mathrm{CH}), 128.8(\mathrm{C}), 128.7(\mathrm{C}), 128.5$ $(\mathrm{CH}), 128.4(\mathrm{CH}), 127.7(\mathrm{CH}), 98.0(\mathrm{CH}, \mathrm{C}-5,2$ epimers $), 87.2(\mathrm{CH}$, $\mathrm{C}-1^{\prime}, 1$ epimer), 86.8 ( $\mathrm{CH}, \mathrm{C}-1^{\prime}, 1$ epimer), 82.7 ( $\mathrm{CH}, \mathrm{C}-4^{\prime}$, 1 epimer), $82.6\left(\mathrm{CH}, \mathrm{C}-4^{\prime}, 1\right.$ epimer), $76.0(\mathrm{~d}, \mathrm{CH}, J=156.5 \mathrm{~Hz}$, PCH, 1 epimer), 75.9 (d, CH, $J=156.7 \mathrm{~Hz}, \mathrm{PCH}, 1$ epimer), 75.3 (CH, C-2', 1 epimer), 74.7 ( $\mathrm{CH}, \mathrm{C}-2^{\prime}, 1$ epimer), 72.6 (CH, C-3', 2 epimers), 71.7-71.4 ( $\mathrm{m}, \mathrm{CH}_{2}, \mathrm{C}-5^{\prime}, 2$ epimers), 54.4-54.1 [m, $\mathrm{CH}_{3},\left(\mathrm{CH}_{3} \mathrm{O}\right)_{2} \mathrm{PO}, 2$ epimers], 53.24, $53.19\left(\mathrm{CH}_{3}, \mathrm{CO}_{2} \mathrm{CH}_{3}, 2\right.$ epimers). C-2 could not be detected. $\delta_{\mathrm{P}}\left(121 \mathrm{MHz} ; \mathrm{CDCl}_{3}\right): 16.47$ (one epimer), 16.20 (one epimer). HRMS (ES+) $\mathrm{m} / \mathrm{z}$ calcd for $\mathrm{C}_{35} \mathrm{H}_{35} \mathrm{~N}_{3} \mathrm{O}_{13} \mathrm{P}[\mathrm{M}+\mathrm{H}]^{+} 736.1908$, found 736.1920. $[\alpha]_{\mathrm{D}}-58.80(\mathrm{c}$ $\left.0.5, \mathrm{CHCl}_{3}, 20{ }^{\circ} \mathrm{C}\right)$.

OH-Insertion Reaction of $3^{\prime}$-O,4- $\mathrm{N}$-Dibenzoyl-2'-deoxycytidine 34b and Trimethyl Phosphonodiazoacetate 20 to Give Phosphonate 49b. Treatment of 34b (490 mg, $1.12 \mathrm{mmol})$ and $\mathbf{2 0}(258 \mathrm{mg}$, $1.24 \mathrm{mmol})$ with rhodium(II) acetate $(\sim 1 \mathrm{~mol} \%)$ by procedure D (chromatography using neat EtOAc) afforded the product $49 \mathrm{~b}$ as a solid (310 $\mathrm{mg}, 45 \%)$. NMR shows roughly a 1:1 mixture of two epimers. $\delta_{\mathrm{H}}\left(400 \mathrm{MHz} ; \mathrm{CDCl}_{3}\right): 8.21(\mathrm{~d}, 0.5 \mathrm{H}, J=8.1 \mathrm{~Hz}$, $\mathrm{H}-6,1$ epimer), 8.08 (bd, $2 \mathrm{H}, J=7.5 \mathrm{~Hz}, \mathrm{ArH}_{\text {ortho }}, 2$ epimers), 8.02 (d, $0.5 \mathrm{H}, J=7.8 \mathrm{~Hz}, \mathrm{H}-6,1$ epimer), 7.84 (bd, $2 \mathrm{H}, J=7.5 \mathrm{~Hz}$, $\mathrm{ArH}_{\text {ortho, }} 2$ epimers), 7.65-7.35 (m, 6H, $\mathrm{ArH}_{\text {para }}, \mathrm{ArH}_{\text {meta }}$ ), 6.81-6.73 (m, 2H, H-5, H-1', 2 epimers), 5.82 (bd, $0.5 \mathrm{H}, J=5.7$ $\mathrm{Hz}, \mathrm{H}-3^{\prime}, 1$ epimer), 5.69 (bd, $0.5 \mathrm{H}, J=5.7 \mathrm{~Hz}, \mathrm{H}-3^{\prime}, 1$ epimer), $4.48(\mathrm{~d}, 0.5 \mathrm{H}, J=18.6 \mathrm{~Hz}, \mathrm{PCH}, 1$ epimer), 4.46 (d, $0.5 \mathrm{H}, J=18.3$ $\mathrm{Hz}, \mathrm{PCH}, 1$ epimer), 4.42-4.39 (bs, $0.5 \mathrm{H}, \mathrm{H}-4^{\prime}, 1$ epimer), $4.38-$ $4.36\left(\mathrm{bs}, 0.5 \mathrm{H}, \mathrm{H}-4^{\prime}, 1\right.$ epimer $), 3.98-3.82\left(\mathrm{~m}, 11 \mathrm{H}, 2 \mathrm{H}-5^{\prime}, 9 \mathrm{CH}_{3}\right)$, 2.76-2.63 (m, $1 \mathrm{H}$, one of $\mathrm{H}-2^{\prime}, 1$ epimer), 2.59-2.44 (m, $1 \mathrm{H}$, one of $\mathrm{H}-2^{\prime}, 1$ epimer). $\delta_{\mathrm{c}}\left(100 \mathrm{MHz} ; \mathrm{CDCl}_{3}\right): 167.08\left(\mathrm{C}, \mathrm{CO}_{2} \mathrm{Me}, 1\right.$ epimer $)$, 167.06 (C, $\mathrm{CO}_{2} \mathrm{Me}, 1$ epimer), 166.99 (NCOPh, 1 epimer), 166.96 (NCOPh, 1 epimer), 166.1 (C, OCOPh, 2 epimers), 162.8 (C, C-4, 2 epimers), 145.6 (C, C-2, 1 epimer), 145.5 (C, C-2, 1 epimer), 133.65 $(\mathrm{CH}), 133.60(\mathrm{CH}), 132.13(\mathrm{C}), 132.10(\mathrm{C}), 130.0(\mathrm{CH}), 129.8$ $(\mathrm{CH}), 129.7(\mathrm{CH}), 129.24(\mathrm{C}), 129.18(\mathrm{C}), 128.9(\mathrm{CH}), 128.6(\mathrm{CH})$, $128.5(\mathrm{CH}), 127.94(\mathrm{CH}), 127.92(\mathrm{CH}), 99.5(\mathrm{CH}, \mathrm{C}-5,1$ epimer $)$, 99.1 (CH, C-5, 1 epimer), 86.3 (CH, C-1' 1 epimer), 85.9 (CH, C-1', 1 epimer), 84.23 ( $\mathrm{CH}, \mathrm{C}-4^{\prime}, 1$ epimer), 84.18 ( $\mathrm{CH}, \mathrm{C}-4^{\prime}, 1$ epimer), 76.4 (CH, C-3', 1 epimer), 76.3 (CH, C-3', 1 epimer), 76.0 (d, $\mathrm{CH}$, $J=157.6 \mathrm{~Hz}, \mathrm{PCH}, 1$ epimer), 75.8 (d, CH, $J=157.6 \mathrm{~Hz}, \mathrm{PCH}$, 1 epimer), 72.6 (d, $\mathrm{CH}_{2}, J=22.1 \mathrm{~Hz}, \mathrm{C}-5^{\prime}, 1$ epimer), 72.5 (d, $\mathrm{CH}_{2}$, $J=22.1 \mathrm{~Hz}, \mathrm{C}-5^{\prime}, 1$ epimer $), 54.1-53.8\left[\mathrm{~m}, \mathrm{CH}_{3},\left(\mathrm{CH}_{3} \mathrm{O}\right)_{2} \mathrm{PO}\right.$, 2 epimers], 53.15-53.08 ( $\mathrm{m}, \mathrm{CH}_{3}, \mathrm{CO}_{2} \mathrm{CH}_{3}, 2$ epimers), $38.3\left(\mathrm{CH}_{2}\right.$, C-2', 1 epimer), 38.1 ( $\mathrm{CH}_{2}, \mathrm{C}-2^{\prime}, 1$ epimer). C-2 could not be detected. $\delta_{\mathrm{P}}\left(121 \mathrm{MHz} ; \mathrm{CDCl}_{3}\right.$ ): 16.53 (one epimer), 16.50 (one epimer). HRMS (ES+) $m / z$ calcd for $\mathrm{C}_{28} \mathrm{H}_{31} \mathrm{~N}_{3} \mathrm{O}_{11} \mathrm{P}[\mathrm{M}+\mathrm{H}]^{+}$ 616.1696, found 616.1669. $[\alpha]_{\mathrm{D}}-20.50\left(\mathrm{c} 0.5, \mathrm{CHCl}_{3}, 20^{\circ} \mathrm{C}\right)$.

$\mathrm{OH}$-Insertion Reaction of $2^{\prime}-O, 3^{\prime}-O, 6-N, N$-Tetrabenzoyladenosine 38a and Trimethyl Phosphonodiazoacetate 20 to Give Phosphonate 50a. Treatment of 38a (3.50 g, $5.12 \mathrm{mmol})$ and 20 (1.60 g, $7.68 \mathrm{mmol})$ with rhodium(II) acetate $(\sim 1 \mathrm{~mol} \%)$ by procedure D (chromatography using EtOAc/hexane, 80:20) afforded the title product $\mathbf{5 0 a}$ as a solid $(2.90 \mathrm{~g}, 66 \%)$. mp: $98-99^{\circ} \mathrm{C}$. NMR shows roughly a 1:1 mixture of two epimers. $\delta_{\mathrm{H}}(300 \mathrm{MHz}$; $\mathrm{CDCl}_{3}$ ): 8.99 (s, $0.5 \mathrm{H}, \mathrm{H}-2$ or $\mathrm{H}-8,1$ epimer), 8.94 (s, $0.5 \mathrm{H}, \mathrm{H}-2$ or 
$\mathrm{H}-8,1$ epimer), 8.66 (s, $0.5 \mathrm{H}, \mathrm{H}-2$ or $\mathrm{H}-8,1$ epimer), 8.64 (s, $0.5 \mathrm{H}$, $\mathrm{H}-2$ or $\mathrm{H}-8,1$ epimer), 8.02-7.81 (m, 8H, ArH $\mathrm{Artho}), 7.60-7.34$ $\left(\mathrm{m}, 12 \mathrm{H}, 4 \mathrm{ArH}_{\text {para }}, 8 \mathrm{ArH}_{\text {meta }}\right), 6.75\left(\mathrm{~d}, 0.5 \mathrm{H}, J=6.6 \mathrm{~Hz}, \mathrm{H}-\mathrm{l}^{\prime}\right.$, 1 epimer), $6.73\left(\mathrm{~d}, 0.5 \mathrm{H}, J=7.2 \mathrm{~Hz}, \mathrm{H}-1^{\prime}, 1\right.$ epimer), $6.29(\mathrm{dd}, 0.5 \mathrm{H}$, $J=7.2,5.4 \mathrm{~Hz}, \mathrm{H}-2^{\prime}, 1$ epimer), 6.14 (m, $1 \mathrm{H}, 0.5 \mathrm{H}-2^{\prime}, 0.5 \mathrm{H}-3^{\prime}$, 1 epimer each), 6.05 (dd, $0.5 \mathrm{H}, J=5.4,2.1 \mathrm{~Hz}, \mathrm{H}-3^{\prime}, 1$ epimer), $4.66-4.61$ (m, 1H, H-4', 2 epimers), 4.53 (d, $0.5 \mathrm{H}, J=18.3 \mathrm{~Hz}$, $\mathrm{PCH}, 1$ epimer), 4.53 (d, $0.5 \mathrm{H}, J=18.3 \mathrm{~Hz}, \mathrm{PCH}, 1$ epimer), 4.16-4.00 (m, 2H, H-5', 2 epimers), 3.94-3.80 (m, 9H, $\mathrm{CH}_{3}$, 2 epimers). $\delta_{\mathrm{c}}\left(75 \mathrm{MHz} ; \mathrm{CDCl}_{3}\right): 172.2\left(\mathrm{C}, \mathrm{CO}_{2} \mathrm{Me}, 2\right.$ epimers$)$, 167.1, $166.9(2 \times \mathrm{C}, \mathrm{NCOPh}, 2$ epimers $), 165.5(\mathrm{C}, \mathrm{OCOPh}$, 2 epimers), 164.8 (C, OCOPh, 2 epimers), 153.6 (C, C-6, 1 epimer), 153.5 (C, C-6, 1 epimer), 152.3 (CH, C-2, 1 epimer), $152.2(\mathrm{CH}$, C-2, 1 epimer), 151.85 (C, C-4, 1 epimer), 151.78 (C, C-4, 1 epimer), 143.9 (CH, C-8, 1 epimer), 143.8 (CH, C-8, 1 epimer), 134.1 (C, 2 epimers), 133.7 ( $\mathrm{CH}, 2$ epimers), 133.6 (CH, 2 epimers), 132.9 ( $\mathrm{CH}, 2$ epimers), 129.85 ( $\mathrm{CH}, 2$ epimers), 129.79 (CH, 2 epimers), 129.5 (CH, 2 epimers), 128.93 (C, 1 epimer), 128.87 (C, 1 epimer), 128.7 (CH, 2 epimers), 128.6 (CH, 2 epimers), 128.5 (C, 2 epimers), 128.4 (CH, 2 epimers), 127.7 (C, C-5, 2 epimers), 85.7 (CH, C-1', 1 epimer), 85.1 ( $\mathrm{CH}, \mathrm{C}-1^{\prime}, 1$ epimer), 83.2 ( $\mathrm{CH}, \mathrm{C}-4^{\prime}, 2$ epimers), $76.4(\mathrm{CH}, \mathrm{d}, J=156.6 \mathrm{~Hz}, \mathrm{PCH}, 1$ epimer), $76.1(\mathrm{CH}, \mathrm{d}, J=156.7$ $\mathrm{Hz}, \mathrm{PCH}, 1$ epimer), 75.1 (CH, C-2', 1 epimer), 74.2 (CH, C-2', 1 epimer), 72.9 ( $\mathrm{CH}, \mathrm{C}-3^{\prime}, 1$ epimer), 72.8 ( $\mathrm{CH}, \mathrm{C}-3^{\prime}, 1$ epimer), $71.9\left(\mathrm{CH}_{2}, \mathrm{~d}, J=10.4 \mathrm{~Hz}, \mathrm{C}-5^{\prime}, 1\right.$ epimer $), 71.6\left(\mathrm{CH}_{2}, \mathrm{~d}, J=11.3 \mathrm{~Hz}\right.$, $\mathrm{C}-5^{\prime}, 1$ epimer $), 54.3-54.1\left[\mathrm{CH}_{3},\left(\mathrm{CH}_{3} \mathrm{O}\right)_{2} \mathrm{PO}, 2\right.$ epimers], 53.2 $\left(\mathrm{CH}_{3}, \mathrm{CO}_{2} \mathrm{CH}_{3}, 1\right.$ epimer), $53.2\left(\mathrm{CH}_{3}, \mathrm{CO}_{2} \mathrm{CH}_{3}, 1\right.$ epimer $) . \delta_{\mathrm{P}}(121$ $\mathrm{MHz} ; \mathrm{CDCl}_{3}$ ): 16.08 (2 epimers). HRMS (ES+) $m / z$ calcd for $\mathrm{C}_{43} \mathrm{H}_{39} \mathrm{~N}_{5} \mathrm{O}_{13} \mathrm{P}[\mathrm{M}+\mathrm{H}]^{+}$864.2282, found 864.2266. $[\alpha]_{\mathrm{D}}-68.29$ (c $0.35, \mathrm{CHCl}_{3}, 20^{\circ} \mathrm{C}$ ).

$\mathrm{OH}$-Insertion Reaction of $3^{\prime}-\mathrm{O}-6-\mathrm{N}, \mathrm{N}$-Tribenzoyl-2'-deoxyadenosine 38b and Trimethyl Diazophosphonoacetate 20 to Give Phosphonate 50b. Treatment of 38b (3.54 g, $6.28 \mathrm{mmol})$ and 20 (1.96 g, $9.41 \mathrm{mmol})$ with rhodium(II) acetate $(\sim 1 \mathrm{~mol} \%)$ by procedure D (chromatography using EtOAc/hexane, 80:20) afforded the title product $\mathbf{5 0 b}$ as a white solid $(1.31 \mathrm{~g}, 28 \%)$. $\mathrm{mp}: 53-54{ }^{\circ} \mathrm{C}$. NMR shows roughly a 1 : 1 mixture of two epimers. $\delta_{\mathrm{H}}\left(300 \mathrm{MHz}, \mathrm{CDCl}_{3}\right): 8.85(\mathrm{~s}, 0.5 \mathrm{H}, \mathrm{H}-2$ or $\mathrm{H}-8$, 1 epimer), $8.821(\mathrm{~s}, 0.5 \mathrm{H}, \mathrm{H}-2$ or $\mathrm{H}-8,1$ epimer), 8.67 (s, $0.5 \mathrm{H}$, $\mathrm{H}-2$ or $\mathrm{H}-8,1$ epimer), 8.65 (s, $0.5 \mathrm{H}, \mathrm{H}-2$ or $\mathrm{H}-8,1$ epimer), 8.07 $\left(\mathrm{dd}, 2 \mathrm{H}, J=6.9,1.5 \mathrm{~Hz}, \mathrm{O}-\mathrm{Bz}, \mathrm{ArH}_{\text {ortho }}\right), 7.86(\mathrm{dd}, 4 \mathrm{H}, J=7.5$, $\left.1.5 \mathrm{~Hz}, \mathrm{~N}-\mathrm{Bz}, \mathrm{ArH}_{\text {ortho }}\right), 7.64-7.28\left(\mathrm{~m}, 9 \mathrm{H}, 3 \mathrm{ArH}_{\text {para }}\right.$, $\left.6 \mathrm{ArH}_{\text {meta }}\right), 6.79-6.70\left(\mathrm{~m}, 1 \mathrm{H}, \mathrm{H}-1^{\prime}, 2\right.$ epimers $), 5.86(\mathrm{~d}, 0.5 \mathrm{H}$, $J=5.7 \mathrm{~Hz}, \mathrm{H}-3^{\prime}, 1$ epimer), $5.79\left(\mathrm{~d}, 0.5 \mathrm{H}, J=5.7 \mathrm{~Hz}, \mathrm{H}-3^{\prime}\right.$, 1 epimer), $4.49-4.42$ ( $\mathrm{m}, 1 \mathrm{H}, \mathrm{H}-4^{\prime}, 2$ epimers), 4.46 (d, $0.5 \mathrm{H}, J=$ $18.6 \mathrm{~Hz}, \mathrm{PCH}, 1$ epimer), 4.45 (d, $0.5 \mathrm{H}, J=18.3 \mathrm{~Hz}, \mathrm{PCH}$, 1 epimer), 4.10-3.95 (m, 2H, H-5', 2 epimers), 3.86-3.78 (m, $9 \mathrm{H}, \mathrm{CH}_{3}, 2$ epimers), 3.16-2.95 (m, $1 \mathrm{H}, 1$ of $\mathrm{H}-2^{\prime}, 2$ epimers), 2.83-2.74 (m, 1H, 1 of $\mathrm{H}-2^{\prime}, 2$ epimers). $\delta \mathrm{c}\left(75 \mathrm{MHz} ; \mathrm{CDCl}_{3}\right)$ : 172.2 (C, $\mathrm{CO}_{2} \mathrm{Me}, 2$ epimers), 167.2 (C, NCOAr, 2 epimers), 167.0 (C, NCOAr, 2 epimers), 166.0 (C, OCOAr, 2 epimers), 153.2 (C, C-6, 1 epimer), 153.0 (C, C-6, 1 epimer), 152.1 (CH, C-2, 1 epimer), 152.0 ( $\mathrm{CH}, \mathrm{C}-2,1$ epimer), 151.7 (C, C-4, 1 epimer), 151.6 (C, C-4, 1 epimer), 144.0 ( $\mathrm{CH}, \mathrm{C}-8,1$ epimer), $143.8(\mathrm{CH}$, C-8, 1 epimer), 134.2 (C, 2 epimers), 133.7 ( $\mathrm{CH}, 1$ epimer), 133.6 ( $\mathrm{CH}, 1$ epimer), 132.9 ( $\mathrm{CH}, 2$ epimers), 129.7 ( $\mathrm{CH}, 2$ epimers), 129.4 (CH, 2 epimers), 129.3 (C, 1 epimer), 129.2 (C, 1 epimer), 128.7 ( $\mathrm{CH}, 2$ epimers), 128.6 ( $\mathrm{CH}, 2$ epimers), 127.8 (C, C-5, 2 epimers), 84.5, 84.4, 84.3, 84.0 ( $\mathrm{CH}, \mathrm{C}-1^{\prime}, \mathrm{C}-4^{\prime}, 2$ epimers), 76.4 (CH, C-3', 1 epimer), 76.3 (CH, C-3', 1 epimer), $76.2(\mathrm{CH}, \mathrm{d}, J=$ $157.4 \mathrm{~Hz}, \mathrm{PCH}, 1$ epimer), $76.1(\mathrm{CH}, \mathrm{d}, J=157.3 \mathrm{~Hz}, \mathrm{PCH}$, 1 epimer), $72.6\left(\mathrm{CH}_{2}, \mathrm{~d}, J=10.3 \mathrm{~Hz}, \mathrm{C}-5^{\prime}, 1\right.$ epimer $), 72.3\left(\mathrm{CH}_{2}, \mathrm{~d}\right.$, $J=11.1 \mathrm{~Hz}, \mathrm{C}-5^{\prime}, 1$ epimer $), 54.2-53.9\left[\mathrm{CH}_{3}, \mathrm{~m},\left(\mathrm{CH}_{3} \mathrm{O}\right)_{2} \mathrm{PO}\right.$, 2 epimers], $53.1\left(\mathrm{CH}_{3}, \mathrm{CO}_{2} \mathrm{CH}_{3}, 1\right.$ epimer $), 53.1\left(\mathrm{CH}_{3}, \mathrm{CO}_{2} \mathrm{CH}_{3}\right.$, 1 epimer), 38.8 ( $\mathrm{CH}_{2}, \mathrm{C}-2^{\prime}, 1$ epimer $), 38.3\left(\mathrm{CH}_{2}, \mathrm{C}-2^{\prime}, 1\right.$ epimer $)$. $\delta_{\mathrm{P}}\left(121 \mathrm{MHz} ; \mathrm{CDCl}_{3}\right): 16.49$ ( 1 epimer), 16.40 (1 epimer). HRMS $\left(\mathrm{ES}^{+}\right) \mathrm{m} / z$ calcd for $\mathrm{C}_{36} \mathrm{H}_{35} \mathrm{~N}_{5} \mathrm{O}_{11} \mathrm{P}[\mathrm{M}+\mathrm{H}]^{+}$744.2071, found 744.2061. $[\alpha]_{\mathrm{D}}\left(\mathrm{c}=0.5, \mathrm{CHCl}_{3}, 20^{\circ} \mathrm{C}\right) 0.476$.
Procedure E: Full Deprotection Reaction. Deprotection of 47b to Give Phosphonate 15b. To a stirring solution of the phosphonate ester $\mathbf{4 7 b}(900 \mathrm{mg}, 1.43 \mathrm{mmol})$ in dichloromethane $(40 \mathrm{~mL})$ was added TMSBr $(0.74 \mathrm{~mL}, 5.70 \mathrm{mmol})$ at room temperature. The reaction mixture was then heated under reflux while stirring for $2 \mathrm{~h}$. The progress of the reaction was monitored by TLC $\left(\mathrm{CH}_{2} \mathrm{Cl}_{2} / \mathrm{MeOH}, 97: 3\right)$. The brown mixture was then treated with water $(25 \mathrm{~mL})$ at room temperature and the reaction mixture was stirred for $10 \mathrm{~min}$ during which time the mixture becomes white milky. Then $\mathrm{NaOH}(1 \mathrm{M}, 10 \mathrm{~mL})$ was added. The reaction mixture was then stirred overnight at room temperature. The layers were separated, the organic layer was extracted twice with water $(2 \times 10 \mathrm{~mL})$. The aqueous phase was acidified $(\mathrm{pH} \approx$ 1.5) using $20 \% \mathrm{HCl}$ and extracted three times with dichloromethane $(3 \times 25 \mathrm{~mL})$. The aqueous phase was then concentrated in vacuo and the acidic residue was purified by a charcoal column using activated carbon Darco G-60 on a sintered glass funnel under vacuum. $\mathrm{pH}$ can be adjusted before adsorption on the charcoal by addition of a solution of $10 \% \mathrm{NH}_{4} \mathrm{OH}$. The product was then eluted with a solution of $20 \% \mathrm{NH}_{4} \mathrm{OH}$. The fractions containing the phosphonate were lyophilized in vacuo to afford the fully deprotected phosphonate as its ammonium salt 15b (350 mg, $57 \%$ ). NMR shows roughly a 3:2 mixture of two epimers, most of the signals in ${ }^{1} \mathrm{H}$ NMR are overlapping; those which can be distinguished are highlighted. $\delta_{\mathrm{H}}\left(300 \mathrm{MHz} ; \mathrm{D}_{2} \mathrm{O}\right): 7.48(\mathrm{~s}, 0.6 \mathrm{H}$, H-6, major epimer), 7.38 (s, 0.4H, H-6, minor epimer), 6.12-6.07 $\left(\mathrm{m}, \mathrm{H}, J=6.9 \mathrm{~Hz}, \mathrm{H}-1^{\prime}\right), 4.34-4.31\left(\mathrm{~m}, 1 \mathrm{H}, \mathrm{H}-3^{\prime}\right), 3.96-3.92(\mathrm{~m}$, $\left.1 \mathrm{H}, \mathrm{H}^{-} 4^{\prime}\right), 3.82(\mathrm{~d}, 0.4 \mathrm{H}, J=16.2 \mathrm{~Hz}, \mathrm{PCH}$, minor epimer), 3.81 (d, $0.6 \mathrm{H}, J=16.5 \mathrm{~Hz}, \mathrm{PCH}$, major epimer $), 3.68-3.35\left(\mathrm{~m}, 2 \mathrm{H}, \mathrm{H}-5^{\prime}\right)$, 2.27-2.07 (m, 2H, H-2'), 1.70-1.69 (bs, 3H, $\left.\mathrm{CH}_{3}-\mathrm{C}-5\right) . \delta_{\mathrm{C}}(75$ $\left.\mathrm{MHz} ; \mathrm{D}_{2} \mathrm{O}\right): 175.6\left(\mathrm{C}, \mathrm{CO}_{2} \mathrm{H}\right.$, minor epimer $), 175.5\left(\mathrm{C}, \mathrm{CO}_{2} \mathrm{H}\right.$, major epimer), 166.5 (C, C-4), 151.7 (C, C-2), 137.6 (CH, C-6, major epimer), 137.4 (CH, C-6, minor epimer), 111.7 (C, C-5), 85.1, 85.0 (2 $\times \mathrm{CH}, \mathrm{C}-1^{\prime}, \mathrm{C}-4^{\prime}$, major epimer $), 85.0,84.8(2 \times \mathrm{CH}$, $\mathrm{C}-1^{\prime}, \mathrm{C}-4^{\prime}$, minor epimer), 80.9 (CH, d, $J=141.5 \mathrm{~Hz}, \mathrm{PCH}$, major epimer), 80.9 (CH, d, $J=140.9 \mathrm{~Hz}, \mathrm{PCH}$, minor epimer), 71.6, $71.5\left(2 \times \mathrm{CH}_{2}, 2 \times \mathrm{d}, J=11.6,12.0 \mathrm{~Hz}, \mathrm{C}-5^{\prime}\right.$, two epimers $), 71.2$ (CH, C-3' ${ }^{\prime}$, major epimer), 71.1 (CH, C-3' ${ }^{\prime}$, minor epimer), 38.1 $\left(\mathrm{CH}_{2}, \mathrm{C}-2^{\prime}\right.$, major epimer $), 37.9\left(\mathrm{CH}_{2}, \mathrm{C}-2^{\prime}\right.$, minor epimer $), 11.5$ $\left(\mathrm{CH}_{3}, \mathrm{CH}_{3}-\mathrm{C}-5\right) . \delta_{\mathrm{P}}\left(121 \mathrm{MHz} ; \mathrm{D}_{2} \mathrm{O}\right): 11.78$ (major epimer), 11.65 (minor epimer). HRMS (ES + ) $m / z$ calcd for $\mathrm{C}_{12} \mathrm{H}_{18} \mathrm{~N}_{2} \mathrm{O}_{10} \mathrm{P}$ $[\mathrm{M}+\mathrm{H}]^{+} 381.0680$, found 381.0699. HPLC 2.75 and $3.22 \mathrm{~min}$ (2 epimers), $96.6 \%$

Deprotection of 48a to Give Phosphonate 16a. Treatment of the phosphonate ester $48 \mathrm{a}(500 \mathrm{mg}, 0.68 \mathrm{mmol})$ by procedure $\mathrm{E}$ with TMSBr $(0.35 \mathrm{~mL}, 2.72 \mathrm{mmol})$ in dichloromethane $(20 \mathrm{~mL})$ for $2 \mathrm{~h}$ then treatment with water $(10 \mathrm{~mL})$ and $\mathrm{NaOH}(1 \mathrm{M}$, $10 \mathrm{~mL}$ ) overnight at room temperature afforded, after charcoal column ( $\mathrm{pH} \sim 1.5$ before adsorption, elution with a solution of $20 \% \mathrm{NH}_{4} \mathrm{OH}$ ), the fully deprotected phosphonate as its ammonium salt 16a (152 mg, 56\%). NMR shows roughly a 5:4 mixture of two epimers. $\delta_{\mathrm{H}}\left(300 \mathrm{MHz} ; \mathrm{D}_{2} \mathrm{O}\right): 8.13(\mathrm{~d}, 0.55 \mathrm{H}, J=8.1 \mathrm{~Hz}$, H-6, major epimer), 8.04 (d, $0.45 \mathrm{H}, J=8.1 \mathrm{~Hz}, \mathrm{H}-6$, minor epimer), 5.92-5.82 (m, 2H, H-1', $\mathrm{H}-5), 4.40-4.19$ (m, 3H, H-4', $\left.\mathrm{H}-3^{\prime}, \mathrm{H}-2^{\prime}\right), 3.96$ (bd, $\left.1 \mathrm{H}, J=17.4 \mathrm{~Hz}, \mathrm{PCH}\right), 3.90-3.51(\mathrm{~m}, 2 \mathrm{H}$, $\left.\mathrm{H}-5^{\prime}\right) . \delta_{\mathrm{C}}\left(75 \mathrm{MHz} ; \mathrm{D}_{2} \mathrm{O}\right): 166.3(\mathrm{C}, \mathrm{C}-4), 151.9(\mathrm{C}, \mathrm{C}-2), 142.8$ (CH, C-6, minor epimer), 142.5 (CH, C-6, major epimer), 102.8 (CH, C-5, minor epimer), 102.6 ( $\mathrm{CH}, \mathrm{C}-5$, major epimer), 89.1 (CH, C-1' ${ }^{\prime}$, minor epimer), 88.8 ( $\mathrm{CH}, \mathrm{C}-1^{\prime}$, major epimer), 83.4 (CH, C-4', minor epimer), 83.3 (CH, C-4', major epimer), 73.8 (CH, C-3', minor epimer), 73.7 (CH, C-3', major epimer), 70.9 $\left(\mathrm{CH}_{2}, \mathrm{~d}, J=12.7 \mathrm{~Hz}, \mathrm{C}-5^{\prime}\right.$, minor epimer $), 70.7\left(\mathrm{CH}_{2}, \mathrm{~d}, J=\right.$ $12.7 \mathrm{~Hz}, \mathrm{C}-5^{\prime}$, major epimer $), 70.2\left(\mathrm{CH}_{2}, \mathrm{C}-2^{\prime}\right.$, minor epimer $)$, $70.1\left(\mathrm{CH}_{2}, \mathrm{C}-2^{\prime}\right.$, major epimer). Signals for $\mathrm{CO}_{2} \mathrm{H}$ and $\mathrm{PCH}$ could not be detected. $\delta_{\mathrm{P}}\left(121 \mathrm{MHz} ; \mathrm{D}_{2} \mathrm{O}\right)$ : 11.74 (major epimer), 11.50 (minor epimer). HRMS (ES+) $\mathrm{m} / z$ calcd for $\mathrm{C}_{11} \mathrm{H}_{16} \mathrm{~N}_{2} \mathrm{O}_{11} \mathrm{P}[\mathrm{M}+\mathrm{H}]^{+}$383.0494, found 383.0492. HPLC 1.20 min (2 epimers), $98.6 \%$. 
Deprotection of 47a to Give Phosphonate 15a. Treatment of the phosphonate ester $47 \mathbf{a}(200 \mathrm{mg}, 0.27 \mathrm{mmol})$ by procedure $\mathrm{E}$ with $\mathrm{TMSBr}(0.14 \mathrm{~mL}, 1.10 \mathrm{mmol})$ in dichloromethane $(20 \mathrm{~mL})$ for $2 \mathrm{~h}$ then treatment with water $(10 \mathrm{~mL})$ and $\mathrm{NaOH}(1 \mathrm{M}, 5 \mathrm{~mL})$ overnight at room temperature afforded, after charcoal column $(\mathrm{pH} \approx 1.5$ before adsorption, elution with a solution of $20 \%$ $\mathrm{NH}_{4} \mathrm{OH}$ ), the fully deprotected phosphonate as its ammonium salt 15a (90 mg, 82\%). NMR shows roughly a 1.2:1 mixture of two epimers. $\delta_{\mathrm{H}}\left(300 \mathrm{MHz} ; \mathrm{D}_{2} \mathrm{O}\right): 7.66(\mathrm{~s}, 0.55 \mathrm{H}, \mathrm{H}-6$, major epimer), $7.53\left(\mathrm{~s}, 0.45 \mathrm{H}, \mathrm{H}-6\right.$, minor epimer), 5.89-5.84 (m, $\left.1 \mathrm{H}, \mathrm{H}-\mathrm{1}^{\prime}\right)$, 4.42-4.31 (m, 1H, H-4'), 4.27-4.22 (m, 1H, H-3'), 4.19-4.12 (m, $\left.1 \mathrm{H}, \mathrm{H}-2^{\prime}\right), 3.96$ (d, $0.45 \mathrm{H}, J=17.4 \mathrm{~Hz}, \mathrm{PCH}$, minor epimer), 3.95 (d, $0.55 \mathrm{H}, J=17.1 \mathrm{~Hz}, \mathrm{PCH}$, major epimer), 3.88-3.48 (m, $2 \mathrm{H}$, $\left.\mathrm{H}-5^{\prime}\right), 1.84$ (s, $1.35 \mathrm{H}, \mathrm{CH}_{3}$, minor epimer), 1.83 (s, $1.65 \mathrm{H}, \mathrm{CH}_{3}$, major epimer). $\delta_{\mathrm{c}}\left(75 \mathrm{MHz} ; \mathrm{D}_{2} \mathrm{O}\right): 166.5,166.4$ (C, C-4, 2 epimers), 151.9 (C, C-2, 2 epimers), 137.7 (CH, C-6, major epimer), 137.3 (CH, C-6, minor epimer), 111.97 (C, C-5, minor epimer), 111.93 (C, C-5, major epimer), 88.5 (CH, C-1', major epimer), $88.4(\mathrm{CH}$, $\mathrm{C}-1^{\prime}$, minor epimer), 83.4 ( $\mathrm{CH}, \mathrm{C}-4^{\prime}$, major epimer), $82.9(\mathrm{CH}$, C-4', minor epimer), $81.2(\mathrm{CH}, \mathrm{d}, J=138.7 \mathrm{~Hz}, \mathrm{PCH}$, minor epimer), $81.2(\mathrm{CH}, \mathrm{d}, J=141.2 \mathrm{~Hz}, \mathrm{PCH}$, major epimer), 73.1 (CH, C-2', major epimer), 72.9 (CH, C-2', minor epimer), 71.571.1 (m, $\mathrm{CH}_{2}, \mathrm{C}-5^{\prime}, 2$ epimers), 70.4 ( $\mathrm{CH}, \mathrm{C}-3^{\prime}$, major epimer), 70.2 (CH, C-3', minor epimer), $11.5\left(\mathrm{CH}_{3}, \mathrm{CH}_{3}-\mathrm{C}-5,2\right.$ epimers). Signals for $\mathrm{CO}_{2} \mathrm{H}$ could not be detected. $\delta_{\mathrm{P}}\left(121 \mathrm{MHz} ; \mathrm{D}_{2} \mathrm{O}\right)$ : 11.83 (major epimer), 11.63 (minor epimer). HRMS (ES+) $\mathrm{m} / z$ calcd for $\mathrm{C}_{12} \mathrm{H}_{18} \mathrm{~N}_{2} \mathrm{O}_{11} \mathrm{P}[\mathrm{M}+\mathrm{H}]^{+} 397.0648$, found 397.0657. HPLC 1.76 and 2.00 min (2 epimers), 95.4\%.

Deprotection of $48 \mathrm{~b}$ to Give Phosphonate 16b. Treatment of the phosphonate ester $\mathbf{4 8 b}(840 \mathrm{mg}, 1.36 \mathrm{mmol})$ by procedure $\mathrm{E}$ with TMSBr $(0.71 \mathrm{~mL}, 5.45 \mathrm{mmol})$ in dichloromethane $(25 \mathrm{~mL})$ for $3 \mathrm{~h}$ then treatment with water $(20 \mathrm{~mL})$ and $\mathrm{NaOH}(1 \mathrm{M}, 10 \mathrm{~mL})$ overnight at room temperature afforded, after charcoal column $(\mathrm{pH} \approx 1.5$ before adsorption, elution with a solution of $20 \%$ $\mathrm{NH}_{4} \mathrm{OH}$ ), the fully deprotected phosphonate as its ammonium salt 16b $(330 \mathrm{mg}, 61 \%)$. NMR shows roughly a $1: 1$ mixture of two epimers. $\delta_{\mathrm{H}}\left(300 \mathrm{MHz} ; \mathrm{D}_{2} \mathrm{O}\right): 7.76$ (2 overlapping d appears as $\mathrm{t}$, $1 \mathrm{H}, J=8.1 \mathrm{~Hz}, \mathrm{H}-6,2$ epimers), $6.28-6.21$ ( $\mathrm{m}, 1 \mathrm{H}, \mathrm{H}-1^{\prime}$, 2 epimers), 5.84 (2 overlapping d appears as $\mathrm{t}, 1 \mathrm{H}, J=7.2 \mathrm{~Hz}, \mathrm{H}-5,2$ epimers), 4.46-4.40 (m, 1H, H-5', 1 epimer), 4.16-4.08 (m, 1H, H-5', 1 epimers), 3.86 (d, $1 \mathrm{H}, J=17.1 \mathrm{~Hz}, \mathrm{PCH}, 2$ epimers), $3.77-3.53$ (m, $2 \mathrm{H}, \mathrm{H}-4^{\prime}, \mathrm{H}-3^{\prime}, 2$ epimers), 2.56-2.29 (m, 2H, H-2', 2 epimers). $\delta_{\mathrm{c}}$ (75 MHz; $\mathrm{D}_{2} \mathrm{O}$ ): 166.3 (C, C-4, 2 epimers), 151.6 (C, C-2, 2 epimers), 142.6 (CH, C-6, one epimer), 142.5 ( $\mathrm{CH}, \mathrm{C}-6$, one epimer), 102.5 (CH, C-5, one epimer), $102.4(\mathrm{CH}, \mathrm{C}-5$, one epimer), $85.6(\mathrm{CH}$, $\mathrm{C}-1^{\prime}, 1$ epimer), 85.5 ( $\mathrm{CH}, \mathrm{C}-1^{\prime}, 1$ epimer), $85.3\left(\mathrm{CH}, \mathrm{C}-4^{\prime}\right.$, one epimer), 85.1 ( $\mathrm{CH}, \mathrm{C}-4^{\prime}$, one epimer), $71.5\left(\mathrm{CH}_{2}, \mathrm{C}-5^{\prime}, 2\right.$ epimers), 71.0 (CH, C-3', 1 epimer), 70.9 (CH, C-3', 1 epimer), $38.5\left(\mathrm{CH}_{2}\right.$, $\mathrm{C}-2^{\prime}, 2$ epimers). Signals for $\mathrm{CO}_{2} \mathrm{H}$ and $\mathrm{PCH}$ could not be detected. $\delta_{\mathrm{P}}\left(121 \mathrm{MHz} ; \mathrm{CDCl}_{3}\right): 10.56$ (2 epimers). HRMS (ES $\left.{ }^{-}\right) \mathrm{m} / z$ calcd for $\mathrm{C}_{11} \mathrm{H}_{14} \mathrm{~N}_{2} \mathrm{O}_{10} \mathrm{P}[\mathrm{M}-\mathrm{H}]^{-}$365.0386, found 365.0381. HPLC 1.57 min (2 epimers), $92.8 \%$.

Deprotection of 49a to Give Phosphonate 17a. Treatment of the phosphonate ester 49a $(2.23 \mathrm{~g}, 3 \mathrm{mmol})$ by procedure $\mathrm{E}$ with TMSBr $(3.15 \mathrm{~mL}, 24.25 \mathrm{mmol})$ in $\mathrm{CH}_{2} \mathrm{Cl}_{2}(50 \mathrm{~mL})$ for $2 \mathrm{~h}$ then treatment with water $(25 \mathrm{~mL})$ and $\mathrm{NaOH}(1 \mathrm{M}, 10 \mathrm{~mL})$ overnight at room temperature afforded, after charcoal column ( $\mathrm{pH} \sim 2.6$ before adsorption, elution with a solution of $20 \% \mathrm{NH}_{4} \mathrm{OH}$ ), the fully deprotected phosphonate as its ammonium salt 17a (690 mg, $57 \%)$. NMR shows roughly a 1:1 mixture of two epimers. $\delta_{\mathrm{H}}(300$ MHz; $\mathrm{D}_{2} \mathrm{O}$ ): 7.92 (d, $0.5 \mathrm{H}, J=7.5 \mathrm{~Hz}, \mathrm{H}-6,1$ epimer), 7.86 (d, $0.5 \mathrm{H}, J=7.5 \mathrm{~Hz}, \mathrm{H}-6,1$ epimer), 5.92 (d, $0.5 \mathrm{H}, J=7.5 \mathrm{~Hz}, \mathrm{H}-5$, 1 epimer), 5.90 (d, $0.5 \mathrm{H}, J=7.5 \mathrm{~Hz}, \mathrm{H}-5,1$ epimer $), 5.80-5.75(\mathrm{~m}$, $1 \mathrm{H}, \mathrm{H}-1^{\prime}, 2$ epimers), 4.90-3.49 (m, 5H, H-3' $\mathrm{H}^{\prime} 4^{\prime}, 2 \times \mathrm{H}-5^{\prime}$, $\mathrm{PCH}, 2$ epimers). $\delta_{\mathrm{c}}\left(75 \mathrm{MHz} ; \mathrm{D}_{2} \mathrm{O}\right): 176.2\left(\mathrm{C}, \mathrm{CO}_{2} \mathrm{H}, 2\right.$ epimers), 165.7 (C, C-4, 2 epimers), 157.2 (C, C-2, 1 epimer), 157.1 (C, C-2, 1 epimer), 142.4 (CH, C-6, 1 epimer), 142.2 (CH, C-6, 1 epimer), 96.5 (CH, C-5, 1 epimer), 96.4 (CH, C-5, 1 epimer), 90.0 (CH, C-1',
1 epimer), 89.7 ( $\mathrm{CH}, \mathrm{C}-1^{\prime}, 1$ epimer), 82.6 ( $\mathrm{CH}, \mathrm{C}-4^{\prime}, 1$ epimer), 82.4 (CH, C-4', 1 epimer), 81.3 (d, $\mathrm{CH}, J=139.6 \mathrm{~Hz}, \mathrm{PCH}, 1$ epimer), 81.2 (d, $\mathrm{CH}, J=139.9 \mathrm{~Hz}, \mathrm{PCH}, 1$ epimer), 74.0 ( $\mathrm{CH}, \mathrm{C}-2^{\prime}, 1$ epimer), 73.9 (CH, C-2', 1 epimer), 70.9-70.6 ( $\mathrm{m}, \mathrm{CH}_{2}, \mathrm{C}-5^{\prime}, 2$ epimers), 69.7 $\left(\mathrm{CH}, \mathrm{C}-3^{\prime}\right.$, epimer), $69.6\left(\mathrm{CH}, \mathrm{C}-3^{\prime}, 1\right.$ epimer). $\delta_{\mathrm{P}}\left(121 \mathrm{MHz} ; \mathrm{D}_{2} \mathrm{O}\right)$ : 11.64 ( 1 epimer), 11.37 ( 1 epimer). HRMS ( $\mathrm{ES}+$ ) $\mathrm{m} / \mathrm{z}$ calcd for $\mathrm{C}_{11} \mathrm{H}_{17} \mathrm{~N}_{3} \mathrm{O}_{10} \mathrm{P}[\mathrm{M}+\mathrm{H}]^{+}$382.0652, found 382.0640. HPLC 0.79 min (2 epimers), $98.2 \%$.

Partial Deprotection of 50a to Give the Mono N-Benzoyl Phosphonate Derivative 18c. Following the procedure E, the phosphonate 50a $(1.18 \mathrm{~g}, 1.37 \mathrm{mmol})$ was treated with TMSBr $(1.77 \mathrm{~mL}$, $13.66 \mathrm{mmol})$ in dichloromethane $(30 \mathrm{~mL})$ for $2 \mathrm{~h}$ then was treated with water $(20 \mathrm{~mL})$ and $\mathrm{NaOH}(1 \mathrm{M}, 20 \mathrm{~mL})$ overnight at room temperature. $\mathrm{pH}$ of the residue was adjusted to $\mathrm{pH} \approx 2.5$ by addition of a solution of $10 \% \mathrm{NH}_{4} \mathrm{OH}$ and the acidic residue was adsorbed on the charcoal. The column was eluted with water then eluted with ammonia $20 \%$. But no organic product has been recovered in these fractions. The monobenzoylated phosphonate 18a (380 mg, 53\%) was recovered as its ammonium salt by eluting with a mixture of ethanol $/ \mathrm{H}_{2} \mathrm{O} / \mathrm{NH}_{4} \mathrm{OH}(10: 10: 3) . \delta_{\mathrm{H}}(300 \mathrm{MHz}$; $\left.\mathrm{D}_{2} \mathrm{O}\right): 8.82(\mathrm{~s}, 0.5 \mathrm{H}, \mathrm{H}-2$ or $\mathrm{H}-8,1$ epimer $), 8.74(\mathrm{~s}, 0.5 \mathrm{H}, \mathrm{H}-2$ or $\mathrm{H}-8,1$ epimer), 8.53 (bs, $1 \mathrm{H}, \mathrm{H}-2$ or $\mathrm{H}-8,2$ epimers), 7.76 (bd, 2H, $J=7.8 \mathrm{~Hz}, \mathrm{ArH}_{\text {ortho, }} 2$ epimers), 7.47 (bt, $1 \mathrm{H}, J=7.2 \mathrm{~Hz}$, $\mathrm{ArH}_{\text {para }}, 2$ epimers), 7.34 (bt, $2 \mathrm{H}, J=7.5 \mathrm{~Hz}, \mathrm{ArH}_{\text {meta }}, 2$ epimers), 6.09 (bd, $1 \mathrm{H}, J=4.8 \mathrm{~Hz}, \mathrm{H}-1^{\prime}, 2$ epimers), 4.50-3.60 (m, 5H, H-4', $\left.\mathrm{H}-2^{\prime}, \mathrm{H}-3^{\prime}, 2 \mathrm{H}-5^{\prime}\right), 3.97(\mathrm{bd}, 1 \mathrm{H}, J=17.1 \mathrm{~Hz}, \mathrm{PCH}) . \delta_{\mathrm{c}}(75 \mathrm{MHz}$; $\left.\mathrm{D}_{2} \mathrm{O}\right): 176.0\left(\mathrm{C}, \mathrm{CO}_{2} \mathrm{H}, 1\right.$ epimer $), 175.9\left(\mathrm{C}, \mathrm{CO}_{2} \mathrm{H}, 1\right.$ epimer $)$, 168.3 (C, NCOPh, 2 epimers), 151.8 (CH, C-2, 2 epimers), 151.6 (C, C-6, 2 epimers), 148.8 (C, C-4, 2 epimers), 143.7 (CH, C-8, 1 epimer), 143.5 (CH, C-8, 1 epimer), $133.2(\mathrm{CH}), 132.4(\mathrm{C}), 128.6$ $(\mathrm{CH}), 127.9(\mathrm{CH}), 123.3$ (C, C-5, 2 epimers), 87.6 (CH, C-1', 1 epimer), 87.3 (CH, C-1', 1 epimer), 84.0 ( $\mathrm{CH}, \mathrm{C}-4^{\prime}, 1$ epimer), 83.8 (CH, C-4', 1 epimer), 81.31 (CH, d, $J=143.2 \mathrm{~Hz}, \mathrm{PCH}, 1$ epimer), $81.29(\mathrm{CH}, \mathrm{d}, J=143.2 \mathrm{~Hz}, \mathrm{PCH}, 1$ epimer), 74.3 (CH, C-2', 1 epimer), 74.2 ( $\mathrm{CH}, \mathrm{C}-2^{\prime}, 1$ epimer), 71.2-71.1 ( $\mathrm{m}, \mathrm{CH}_{2}, \mathrm{C}-5^{\prime}$, 2 epimers), 70.8 ( $\mathrm{CH}, \mathrm{C}-3^{\prime}, 1$ epimer), 70.7 ( $\mathrm{CH}, \mathrm{C}-3^{\prime}, 1$ epimer). $\delta_{\mathrm{P}}\left(121 \mathrm{MHz} ; \mathrm{D}_{2} \mathrm{O}\right): 11.79$ (1 epimer), 11.70 (1 epimer). HRMS (ES+) $m / z$ calcd for $\mathrm{C}_{19} \mathrm{H}_{21} \mathrm{~N}_{5} \mathrm{O}_{10} \mathrm{P}[\mathrm{M}+\mathrm{H}]^{+} 510.1026$, found 510.1031 .

Full Deprotection of 50a to Give Phosphonate 18a. Treatment of the phosphonate $\mathbf{5 0 a}(1.45 \mathrm{~g}, 1.68 \mathrm{mmol})$ by procedure $\mathrm{E}$ with $\operatorname{TMSBr}(2.18 \mathrm{~mL}, 16.80 \mathrm{mmol})$ in dichloromethane $(30 \mathrm{~mL})$ for $2 \mathrm{~h}$ then treatment with water $(20 \mathrm{~mL})$ and $\mathrm{NaOH}(1 \mathrm{M}, 20 \mathrm{~mL})$ overnight at reflux temperature afforded, after charcoal column ( $\mathrm{pH} \approx 2.5$ before adsorption, elution with a solution of $20 \%$ $\mathrm{NH}_{4} \mathrm{OH}$ ), the fully deprotected phosphonate as its ammonium salt 18a $(430 \mathrm{mg}, 61 \%) . \delta_{\mathrm{H}}\left(300 \mathrm{MHz} ; \mathrm{D}_{2} \mathrm{O}\right): 8.44$ (bs, $1 \mathrm{H}, \mathrm{H}-2$ or $\mathrm{H}-8$, 2 epimers), 8.02 (s, $1 \mathrm{H}, \mathrm{H}-2$ or $\mathrm{H}-8,2$ epimers), 5.96 (bd, $1 \mathrm{H}, J=$ $5.1 \mathrm{~Hz}, \mathrm{H}-1^{\prime}, 2$ epimers), 4.38-3.30 (m, 6H, PCH, H-4', H-2', H-3', $\left.2 \mathrm{H}-5^{\prime}\right) . \delta \mathrm{c}\left(75 \mathrm{MHz} ; \mathrm{D}_{2} \mathrm{O}\right): 176.8\left(\mathrm{C}, \mathrm{CO}_{2} \mathrm{H}, 2\right.$ epimers), $155.1(\mathrm{C}$, C-6, 2 epimers), 152.5 (CH, C-2, 2 epimers), 148.5 (C, C-4, 2 epimers), 140.2 (br CH, C-8, 2 epimers), 118.2 (C, C-5, 2 epimers), 87.3 (CH, C-1' 1 epimer), 87.1 ( $\mathrm{CH}, \mathrm{C}-1^{\prime}, 1$ epimer), $83.5(\mathrm{CH}$, C-4', 1 epimer), 83.3 (CH, C-4', 1 epimer), 73.9 (CH, C-2', 2 epimers), 71.4-71.3 (m, $\mathrm{CH}_{2}, \mathrm{C}-5^{\prime}, 2$ epimers), $70.6(\mathrm{CH}$, $\mathrm{C}-3^{\prime}, 2$ epimers). $\delta_{\mathrm{P}}\left(121 \mathrm{MHz} ; \mathrm{D}_{2} \mathrm{O}\right): 11.30$ (2 epimers). HRMS (ES+) $m / z$ calcd for $\mathrm{C}_{12} \mathrm{H}_{17} \mathrm{~N}_{5} \mathrm{O}_{9} \mathrm{P}[\mathrm{M}+\mathrm{H}]^{+} 406.0764$, found 406.0765. HPLC 2.15 and $2.67 \mathrm{~min}$ ( 2 epimers), $96.6 \%$.

$\boldsymbol{N}^{2}$-[(Dimethylamino)methylene $]$ guanosine $44 .^{29}$ Guanosine $(5.0 \mathrm{~g}, 17.6 \mathrm{~mol})$ was dissolved in $50 \mathrm{~mL}$ of anhydrous methanol, and $9.4 \mathrm{~mL}$ ( $8.4 \mathrm{~g}, 70.6 \mathrm{~mol})$ of $N, N$-dimethylformamide dimethyl acetal was added under nitrogen. The suspension was stirred overnight at room temperature. The resulting white precipitate was removed by filtration, washed with cold methanol $(2 \times 10 \mathrm{~mL})$, and dried in vacuo to afford the title product $\mathbf{4 4}$ as a white solid (5.32 g, $89 \%$ ). mp: $245-246^{\circ} \mathrm{C}\left(\right.$ lit. $\left.^{29} 247-248^{\circ} \mathrm{C}\right) . \delta_{\mathrm{H}}(300 \mathrm{MHz}$; $\left.\mathrm{D}_{2} \mathrm{O}\right): 8.22(\mathrm{~s}, 1 \mathrm{H}, \mathrm{N}=\mathrm{CH}-\mathrm{N}), 7.96(\mathrm{~s}, 1 \mathrm{H}, \mathrm{H}-8), 5.85(\mathrm{~d}, 1 \mathrm{H}, J=$ $\left.5.7 \mathrm{~Hz}, \mathrm{H}-1^{\prime}\right), 4.64$ (bt, $\left.1 \mathrm{H}, J=5.4 \mathrm{~Hz}, \mathrm{H}-2^{\prime}\right), 4.33$ (dd appears as t, 
$\left.1 \mathrm{H}, J=4.2 \mathrm{~Hz}, \mathrm{H}-3^{\prime}\right), 4.17-4.12(\mathrm{X}$ part of ABX, 1H, H-4' $), 3.82$ (A part of ABX, $1 \mathrm{H}, J=12.6,3.0 \mathrm{~Hz}$, one of $\left.\mathrm{H}-5^{\prime}\right), 3.73$ (B part of ABX, $1 \mathrm{H}, J=12.6,4.2 \mathrm{~Hz}$, one of $\left.\mathrm{H}-5^{\prime}\right), 3.08(\mathrm{~s}, 3 \mathrm{H}), 2.90(\mathrm{~s}, 3 \mathrm{H})$. $\delta_{\mathrm{C}}\left(75 \mathrm{MHz}\right.$; DMSO- $\left.d_{6}\right): 157.9(\mathrm{CH}, \mathrm{N}=\mathrm{CH}-\mathrm{N}), 157.6(\mathrm{C}, \mathrm{C}-6$ or C-2), 157.2 (C, C-6 or C-2), 150.0 (C, C-4), 137.0 (CH, C-8), 119.7 (C, C-5), $86.7\left(\mathrm{CH}, \mathrm{C}-1^{\prime}\right.$ or $\left.\mathrm{C}-4^{\prime}\right), 85.4\left(\mathrm{CH}, \mathrm{C}-4^{\prime}\right.$ or $\left.\mathrm{C}-1^{\prime}\right), 73.8$ $\left(\mathrm{CH}, \mathrm{C}-2^{\prime}\right.$ or $\left.\mathrm{C}-3^{\prime}\right), 70.5\left(\mathrm{CH}, \mathrm{C}-2^{\prime}\right.$ or $\left.\mathrm{C}-3^{\prime}\right), 61.5\left(\mathrm{CH}_{2}, \mathrm{C}-5^{\prime}\right), 40.6$ $\left(\mathrm{CH}_{3}\right), 34.6\left(\mathrm{CH}_{3}\right)$. HRMS $\left(\mathrm{ES}^{+}\right) m / z$ calcd for $\mathrm{C}_{13} \mathrm{H}_{19} \mathrm{~N}_{6} \mathrm{O}_{5}[\mathrm{M}+$ $\mathrm{H}]^{+} 339.1417$, found 339.1411 .

$5^{\prime}$-O-tert-Butyldimethylsilyl-2'-O, $3^{\prime}-O, N^{1}$-tribenzoyl, $N^{2}-[($ dimethylamino)methylene]guanosine 45 . To a precooled mixture of $\mathbf{4 4}$ $(4.00 \mathrm{~g}, 11.82 \mathrm{mmol})$ and pyridine $(100 \mathrm{~mL})$, TBDMSCl $(1.96 \mathrm{~g}$, $13.01 \mathrm{mmol}$ ) was added in one portion at $0{ }^{\circ} \mathrm{C}$. After stirring for 30 min at $0{ }^{\circ} \mathrm{C}$, the reaction mixture was allowed to warm at room temperature and was further stirred overnight. After completion of the reaction, the reaction mixture was cooled down to $0^{\circ} \mathrm{C}$, and benzoyl chloride $(5.49 \mathrm{~mL}, 47.3 \mathrm{mmol})$ was added and the reaction mixture was stirred overnight at room temperature. The mixture was then concentrated in vacuo, diluted with $\mathrm{CH}_{2} \mathrm{Cl}_{2}(60 \mathrm{~mL})$ washed with several times with a solution of $\mathrm{HCl}(20 \%)(6 \times 30$ $\mathrm{mL})$, then with a solution of saturated $\mathrm{NaHCO}_{3}(6 \times 30 \mathrm{~mL})$ then with water $(3 \times 30 \mathrm{~mL})$. The crude product was purified by flash chromatography using $\mathrm{CH}_{2} \mathrm{Cl}_{2}$ to $\mathrm{CH}_{2} \mathrm{Cl}_{2} / \mathrm{MeOH}$ (98/1) as eluent to afford the product 45 as a white solid (6.60 g, 73\%). mp: $109-110^{\circ} \mathrm{C} . \delta_{\mathrm{H}}\left(300 \mathrm{MHz} ; \mathrm{CDCl}_{3}\right): 8.70(2$ overlapping bs, $1 \mathrm{H}$, $\mathrm{N}=\mathrm{CH}-\mathrm{N}), 8.01-7.87\left(\mathrm{~m}, 7 \mathrm{H}, 6 \mathrm{ArH}_{\text {ortho }}, \mathrm{H}-8\right), 7.60-7.51(\mathrm{~m}$, $\left.3 \mathrm{H}, \mathrm{ArH}_{\text {para }}\right), 7.46-7.34\left(\mathrm{~m}, 6 \mathrm{H}, \mathrm{ArH}_{\text {meta }}\right), 6.48(\mathrm{dd}, 1 \mathrm{H}, J=5.4$, $\left.3.6 \mathrm{~Hz}, \mathrm{H}-2^{\prime}\right), 6.24\left(\mathrm{~d}, 1 \mathrm{H}, J=3.9 \mathrm{~Hz}, \mathrm{H}-1^{\prime}\right), 6.21-6.12(\mathrm{~m}, 1 \mathrm{H}$, $\mathrm{H}-3^{\prime}$ ), 4.57-4.50 (X part of ABX, 1H, H-4'), 4.10-3.91 (AB part of $\left.\mathrm{ABX}, 2 \mathrm{H}, \mathrm{H}-5^{\prime}\right), 3.12(\mathrm{~s}, 3 \mathrm{H}), 2.69(\mathrm{~s}, 3 \mathrm{H}), 0.87$ [s, 9H, $\left.\mathrm{C}\left(\mathrm{CH}_{3}\right)_{3}\right], 0.08\left(\mathrm{~s}, 3 \mathrm{H}, \mathrm{SiCH}_{3}\right), 0.05\left(\mathrm{~s}, 3 \mathrm{H}, \mathrm{SiCH}_{3}\right) . \delta_{\mathrm{C}}(75$ $\mathrm{MHz} ; \mathrm{CDCl}_{3}$ ): 170.9 (C), 165.5 (C), 165.1 (C), 157.2 (C, C-6 or $\mathrm{C}-2), 157.1(\mathrm{CH}, \mathrm{N}=\mathrm{CH}-\mathrm{N}), 155.7(\mathrm{C}, \mathrm{C}-6$ or $\mathrm{C}-2), 149.1(\mathrm{C}$, C-4), $137.5(\mathrm{CH}, \mathrm{C}-8), 133.9(\mathrm{CH}), 133.64(\mathrm{CH}), 133.60(\mathrm{CH})$, $133.3(\mathrm{C}), 130.2(\mathrm{CH}), 129.8(\mathrm{CH}), 129.7(\mathrm{CH}), 129.0(\mathrm{C}), 128.9$ (C), $128.7(\mathrm{CH}), 128.5(\mathrm{CH}), 120.7(\mathrm{C}, \mathrm{C}-5), 87.3\left(\mathrm{CH}, \mathrm{C}^{\prime} \mathbf{1}^{\prime}\right)$, $82.7\left(\mathrm{CH}, \mathrm{C}-4^{\prime}\right), 74.3\left(\mathrm{CH}, \mathrm{C}-2^{\prime}\right), 71.1\left(\mathrm{CH}, \mathrm{C}-3^{\prime}\right), 62.5\left(\mathrm{CH}_{2}\right.$, $\left.\mathrm{C}-5^{\prime}\right), 40.9\left(\mathrm{CH}_{3}\right), 35.0\left(\mathrm{CH}_{3}\right), 25.9\left[\mathrm{CH}_{3}, \mathrm{SiC}\left(\mathrm{CH}_{3}\right)_{3}\right], 18.4[\mathrm{C}$, $\left.\mathrm{SiC}\left(\mathrm{CH}_{3}\right)_{3}\right],-5.5\left[\mathrm{CH}_{3}, \mathrm{Si}\left(\mathrm{CH}_{3}\right)_{2}\right]$. HRMS $\left(\mathrm{ES}^{+}\right) \mathrm{m} / z$ calcd for $\mathrm{C}_{40} \mathrm{H}_{45} \mathrm{~N}_{6} \mathrm{O}_{8} \mathrm{Si}[\mathrm{M}+\mathrm{H}]^{+}$765.3068, found 765.3052.

$2^{\prime}-O, 3^{\prime}-O, N^{1}$-Tribenzoyl, $N^{2}$-[(dimethylamino)methylene $]$ guanosine 46. To a stirred solution of $\mathbf{4 5}(1.50 \mathrm{~g}, 1.96 \mathrm{mmol})$ in THF $(36 \mathrm{~mL})$ was added aqueous TFA $\left(18 \mathrm{~mL}, \mathrm{TFA} / \mathrm{H}_{2} \mathrm{O}, 1: 1\right)$ at $0{ }^{\circ} \mathrm{C}$. After stirring for $3 \mathrm{~h}$ at room temperature, the reaction mixture was neutralized carefully with a solution of saturated $\mathrm{NaHCO}_{3}(60 \mathrm{~mL})$ and diluted with EtOAc $(40 \mathrm{~mL})$. The aqueous phase was extracted with EtOAc $(3 \times 40 \mathrm{~mL})$. The combined organic phases were washed with water $(2 \times 50 \mathrm{~mL})$, dried over $\mathrm{MgSO}_{4}$, filtered and concentrated in vacuo. The title product was purified by flash chromatography using EtOAc/ hexane $(20: 80)$ to afford the product 46 as white solid $(1.05 \mathrm{~g}$, $82 \%)$ mp: $154-155^{\circ} \mathrm{C} . \delta_{\mathrm{H}}\left(300 \mathrm{MHz} ; \mathrm{CDCl}_{3}\right): 8.58$ (2 overlapping bs, $1 \mathrm{H}, \mathrm{N}=\mathrm{CH}-\mathrm{N}), 8.01-7.85\left(\mathrm{~m}, 6 \mathrm{H}, 6 \mathrm{ArH}_{\mathrm{ortho}}\right)$, $7.77(\mathrm{~s}, 1 \mathrm{H}, \mathrm{H}-8), 7.61-7.50\left(\mathrm{~m}, 3 \mathrm{H}, \mathrm{ArH}_{\text {para }}\right), 7.47-7.33(\mathrm{~m}$, $\left.6 \mathrm{H}, \mathrm{ArH}_{\text {meta }}\right), 6.49-6.40\left(\mathrm{~m}, 1 \mathrm{H}, \mathrm{H}-2^{\prime}\right), 6.18(\mathrm{~d}, 1 \mathrm{H}, J=6.0 \mathrm{~Hz}$, $\left.\mathrm{H}-1^{\prime}\right), 6.16-6.10\left(\mathrm{~m}, 1 \mathrm{H}, \mathrm{H}-3^{\prime}\right), 4.57-4.52(\mathrm{X}$ part of ABX, 1H, $\mathrm{H}-4^{\prime}$ ), 4.04 (A part of $\mathrm{ABX}, 1 \mathrm{H}, J=12.6,1.8 \mathrm{~Hz}$, one of $\mathrm{H}-5^{\prime}$ ), 3.91 (B part of ABX, $1 \mathrm{H}, J=11.7 \mathrm{~Hz}$, one of $\left.\mathrm{H}-5^{\prime}\right), 3.15(\mathrm{~s}, 3 \mathrm{H})$, $2.70(\mathrm{~s}, 3 \mathrm{H}) . \delta_{\mathrm{C}}\left(75 \mathrm{MHz} ; \mathrm{CDCl}_{3}\right): 170.6(\mathrm{C}), 165.5(\mathrm{C}), 165.0$ (C), $157.4(\mathrm{CH}, \mathrm{N}=\mathrm{CH}-\mathrm{N}), 157.1(\mathrm{C}, \mathrm{C}-6$ or C-2), $156.1(\mathrm{C}, \mathrm{C}-6$ or C-2), 148.8 (C, C-4), 138.7 (CH, C-8), $134.1(\mathrm{CH}), 133.73$ $(\mathrm{CH}), 133.67(\mathrm{CH}), 133.0(\mathrm{C}), 130.3(\mathrm{CH}), 129.8(\mathrm{CH}), 129.7$ $(\mathrm{CH}), 129.0(\mathrm{C}), 128.8(\mathrm{CH}), 128.6(\mathrm{CH}), 128.5(\mathrm{CH}), 121.5(\mathrm{C}$, C-5), $88.5\left(\mathrm{CH}, \mathrm{C}-1^{\prime}\right), 84.7\left(\mathrm{CH}, \mathrm{C}-4^{\prime}\right), 73.4\left(\mathrm{CH}, \mathrm{C}-2^{\prime}\right), 72.2$ $\left(\mathrm{CH}, \mathrm{C}-3^{\prime}\right), 62.1\left(\mathrm{CH}_{2}, \mathrm{C}-5^{\prime}\right), 41.2\left(\mathrm{CH}_{3}\right), 35.0\left(\mathrm{CH}_{3}\right)$. Many signals in ${ }^{1} \mathrm{H}$ and ${ }^{13} \mathrm{C}$ are broadened showing evidence of two rotamers. HRMS $\left(\mathrm{ES}^{+}\right) m / z$ calcd for $\mathrm{C}_{34} \mathrm{H}_{31} \mathrm{~N}_{6} \mathrm{O}_{8}[\mathrm{M}+\mathrm{H}]^{+}$ 651.2203, found 651.2226 .
$\mathbf{5}^{\prime}$-O-tert-Butyldimethylsilyl-2,3'-anhydrothymidine $\mathbf{5 1}$. $^{35 \mathrm{~b}} \mathrm{~A}$ solution containing $5^{\prime}$-O-tert-butyldimethylsilylthymidine $\mathbf{2 4 b}$ $(2.50 \mathrm{~g}, 7.01 \mathrm{mmol})$ and triphenylphosphine $(3.68 \mathrm{~g}, 14.03$ $\mathrm{mmol})$ in DMF $(20 \mathrm{~mL})$ was prepared. Diisopropyl azodicarboxylate $(2.73 \mathrm{~mL}, 14.03 \mathrm{mmol})$ was added dropwise while stirring at room temperature. The reaction was stirred at room temperature overnight. Then, solvent was evaporated in vacuo. The residue was diluted with dichloromethane $(20 \mathrm{~mL})$, washed with water $(3 \times 10 \mathrm{~mL})$, dried over $\mathrm{MgSO}_{4}$, filtered and concentrated in vacuo. The crude was purified by chromatography column using neat EtOAc to remove $\mathrm{OPPh}_{3}$ then neat acetone as eluent to afford the product $\mathbf{5 1}$ as a white solid $(1.90 \mathrm{~g}, 80 \%)$. mp: $171-172{ }^{\circ} \mathrm{C}\left(\right.$ lit.: $\left.{ }^{35 \mathrm{~b}} 175-176^{\circ} \mathrm{C}\right) . \delta_{\mathrm{H}}\left(300 \mathrm{MHz} ; \mathrm{CDCl}_{3}\right)$ : 7.16 (finely split s, $1 \mathrm{H}, \mathrm{H}-6), 5.73\left(\mathrm{~d}, 1 \mathrm{H}, J=3.6 \mathrm{~Hz}, \mathrm{H}-1^{\prime}\right), 5.20$ (bs, $\left.1 \mathrm{H}, \mathrm{H}-3^{\prime}\right), 4.34-4.25\left(\mathrm{~m}, 1 \mathrm{H}, \mathrm{H}-4^{\prime}\right), 3.81$ (A part of ABX, $J=10.1,7.2 \mathrm{~Hz}$, one of $\left.\mathrm{H}-5^{\prime}\right), 3.74$ (B part of ABX, $1 \mathrm{H}, J=10.1$, $7.2 \mathrm{~Hz}$, one of $\left.\mathrm{H}-5^{\prime}\right), 2.84-2.78\left(\mathrm{~m}, 1 \mathrm{H}\right.$, one of $\left.\mathrm{H}-2^{\prime}\right), 2.52-2.44$ $\left(\mathrm{m}, 1 \mathrm{H}\right.$, one of $\left.\mathrm{H}-2^{\prime}\right), 1.90\left(\mathrm{~s}, 3 \mathrm{H}, \mathrm{CH}_{3}\right), 0.89\left[\mathrm{~s}, 9 \mathrm{H}, \mathrm{C}\left(\mathrm{CH}_{3}\right)_{3}\right], 0.06$ $\left(\mathrm{s}, 6 \mathrm{H}, 2 \times \mathrm{SiCH}_{3}\right) . \delta_{\mathrm{c}}\left(75 \mathrm{MHz} ; \mathrm{CDCl}_{3}\right): 172.1(\mathrm{C}, \mathrm{C}-4), 153.7(\mathrm{C}$, C-2), 135.8 (CH, C-6), 117.8 (C, C-5), 87.5 (CH, C-1'), 85.7 (CH, $\left.\mathrm{C}-4^{\prime}\right), 76.7\left(\mathrm{CH}, \mathrm{C}-3^{\prime}\right), 61.2\left(\mathrm{CH}_{2}, \mathrm{C}-5^{\prime}\right), 33.4\left(\mathrm{CH}_{2}, \mathrm{C}-2^{\prime}\right), 25.7\left[\mathrm{CH}_{3}\right.$, $\left.\mathrm{SiC}\left(\mathrm{CH}_{3}\right)_{3}\right], 18.4\left[\mathrm{C}, \mathrm{SiC}\left(\mathrm{CH}_{3}\right)_{3}\right], 13.3\left(\mathrm{CH}_{3}, \mathrm{CH}_{3}-\mathrm{C}-5\right),-5.5\left[\mathrm{CH}_{3}\right.$, $\left.\mathrm{Si}\left(\mathrm{CH}_{3}\right)_{2}\right]$. HRMS (ES+) $m / z$ calcd for $\mathrm{C}_{16} \mathrm{H}_{27} \mathrm{~N}_{2} \mathrm{O}_{4} \mathrm{Si}[\mathrm{M}+\mathrm{H}]^{+}$ 339.1740 , found 339.1732. $v_{\max } \mathrm{cm}^{-1}$ (film) 2928, 1659, 1620, 1528, 1471, 1271, 1137, 1078, 837, 779 .

$\mathbf{5}^{\prime}$-O-tert-Butyldimethylsilyl-3' -azido-3'-deoxythymidine $\mathbf{5 2 .}{ }^{35 \mathrm{~b}}$ A mixture of sodium azide $(2.74 \mathrm{~g}, 42.1 \mathrm{mmol})$ and $\mathbf{5 1}(2.85 \mathrm{~g}$, $8.42 \mathrm{mmol})$ in DMF $(25 \mathrm{~mL})$ was heated at $110^{\circ} \mathrm{C}$ while stirring overnight. Then, solvent was evaporated in vacuo and the crude product was diluted in dichloromethane $(30 \mathrm{~mL})$, washed 3 times with water $(3 \times 10 \mathrm{~mL})$, dried over $\mathrm{MgSO}_{4}$, filtered and concentrated in vacuo. Purification by flash chromatography using hexane/EtOAc (70:30) to hexane/EtOAc (50:50) afforded the product 52 as a clear oil $(2.05 \mathrm{~g}, 64 \%) . \delta_{\mathrm{H}}\left(300 \mathrm{MHz} ; \mathrm{CDCl}_{3}\right): 7.39$ (finely split s, $1 \mathrm{H}, \mathrm{H}-6), 6.18\left(\mathrm{t}, 1 \mathrm{H}, J=6.3 \mathrm{~Hz}, \mathrm{H}-1^{\prime}\right), 4.22-4.14(\mathrm{~m}, 1 \mathrm{H}$, $\left.\mathrm{H}-3^{\prime}\right), 3.94-3.84\left(\mathrm{~m}, 2 \mathrm{H}, \mathrm{H}-4^{\prime}\right.$, one of $\left.\mathrm{H}-5^{\prime}\right), 3.75$ (B part of ABX, $1 \mathrm{H}, J=9.3,1.9 \mathrm{~Hz}$, one of $\left.\mathrm{H}-5^{\prime}\right), 2.43-2.33\left(\mathrm{~m}, 1 \mathrm{H}\right.$, one of $\left.\mathrm{H}-2^{\prime}\right)$, $2.23-2.10\left(\mathrm{~m}, 1 \mathrm{H}\right.$, one of $\left.\mathrm{H}-2^{\prime}\right), 1.86$ (finely split s, $\left.3 \mathrm{H}, \mathrm{CH}_{3}\right), 0.87$ $\left[\mathrm{s}, 9 \mathrm{H}, \mathrm{C}\left(\mathrm{CH}_{3}\right)_{3}\right], 0.07\left(\mathrm{~s}, 6 \mathrm{H}, 2 \times \mathrm{SiCH}_{3}\right) . \delta_{\mathrm{c}}\left(75 \mathrm{MHz} ; \mathrm{CDCl}_{3}\right)$ : 164.2 (C, C-4), 150.5 (C, C-2), 135.1 (CH, C-6), 111.0 (C, C-5), 84.5 $\left(\mathrm{CH}, \mathrm{C}-1^{\prime}\right), 84.4\left(\mathrm{CH}, \mathrm{C}-4^{\prime}\right), 62.9\left(\mathrm{CH}_{2}, \mathrm{C}-5^{\prime}\right), 60.5\left(\mathrm{CH}, \mathrm{C}-3^{\prime}\right), 38.0$ $\left(\mathrm{CH}_{2}, \mathrm{C}-2^{\prime}\right), 25.9\left[\mathrm{CH}_{3}, \mathrm{SiC}\left(\mathrm{CH}_{3}\right)_{3}\right], 18.4\left[\mathrm{C}, \mathrm{SiC}\left(\mathrm{CH}_{3}\right)_{3}\right], 12.6$ $\left(\mathrm{CH}_{3}, \mathrm{CH}_{3}-\mathrm{C}-5\right),-5.5\left[\mathrm{CH}_{3}, \mathrm{Si}\left(\mathrm{CH}_{3}\right)_{2}\right]$. HRMS (ES+) $\mathrm{m} / z$ calcd for $\mathrm{C}_{16} \mathrm{H}_{28} \mathrm{~N}_{5} \mathrm{O}_{4} \mathrm{Si}[\mathrm{M}+\mathrm{H}]^{+} 382.1911$, found 382.1917. $v_{\max } \mathrm{cm}^{-1}$ (film) 2928, 2105, 1692, 1470, 1259, 1126, 836, 779.

$\mathbf{5}^{\prime}$-O-tert-Butyldimethylsilyl-3' -azido-3'-deoxy,3- $N$-benzoylthymidine 53. Treatment of $\mathbf{5 2}(1.75 \mathrm{~g}, 4.59 \mathrm{mmol})$, benzoyl chloride (1.06 mL, $9.17 \mathrm{mmol})$, triethylamine $(1.28 \mathrm{~mL}, 9.17 \mathrm{mmol})$ and dimethylaminopyridine (450 mg, $3.67 \mathrm{mmol}$ ) in dichloromethane $\left(20 \mathrm{~mL}\right.$ ) by procedure $\mathrm{B}$ (chromatography using neat $\mathrm{CH}_{2} \mathrm{Cl}_{2}$ ) afforded the product 53 as a clear oil $(1.90 \mathrm{~g}, 85 \%) . \delta_{\mathrm{H}}(300 \mathrm{MHz}$; $\mathrm{CDCl}_{3}$ ): $7.93\left(\mathrm{dd}, 2 \mathrm{H}, J=6.9,1.5 \mathrm{~Hz}, \mathrm{ArH}_{\text {ortho }}\right), 7.65$ (bt, $1 \mathrm{H}$, $\left.J=7.5,1.2 \mathrm{~Hz}, \mathrm{ArH}_{\text {para }}\right), 7.57$ (finely split s, $\left.1 \mathrm{H}, \mathrm{H}-6\right), 7.49(\mathrm{t}, 2 \mathrm{H}$, $\left.J=7.8 \mathrm{~Hz}, \mathrm{ArH}_{\text {meta }}\right), 6.21\left(\mathrm{t}, 1 \mathrm{H}, J=6.6 \mathrm{~Hz}, \mathrm{H}-\mathrm{l}^{\prime}\right), 4.30-4.22(\mathrm{~m}$, $\left.1 \mathrm{H}, \mathrm{H}-3^{\prime}\right), 3.99-3.91\left(\mathrm{~m}, 2 \mathrm{H}, \mathrm{H}-4^{\prime}\right.$, one of $\left.\mathrm{H}-5^{\prime}\right), 3.81$ (B part of ABX, $1 \mathrm{H}, J=9.0,2.1 \mathrm{~Hz}$, one of $\left.\mathrm{H}-5^{\prime}\right), 2.49-2.39(\mathrm{~m}, 1 \mathrm{H}$, one of $\left.\mathrm{H}-2^{\prime}\right), 2.33-2.23\left(\mathrm{~m}, 1 \mathrm{H}\right.$, one of $\left.\mathrm{H}-2^{\prime}\right), 1.96$ (finely split s, $3 \mathrm{H}$, $\left.\mathrm{CH}_{3}\right), 0.96\left[\mathrm{~s}, 9 \mathrm{H}, \mathrm{C}\left(\mathrm{CH}_{3}\right)_{3}\right], 0.15\left(\mathrm{~s}, 6 \mathrm{H}, 2 \times \mathrm{SiCH}_{3}\right) . \delta_{\mathrm{c}}(75 \mathrm{MHz}$; $\mathrm{CDCl}_{3}$ ): 168.9 (C), 162.7 (C, C-4), 149.2 (C, C-2), 135.1 (CH, C-6), $131.5(\mathrm{C}), 130.4(\mathrm{CH}), 129.2(\mathrm{CH}), 110.9(\mathrm{C}, \mathrm{C}-5), 84.9\left(\mathrm{CH}, \mathrm{C}-1^{\prime}\right)$, $84.7\left(\mathrm{CH}, \mathrm{C}-4^{\prime}\right), 63.0\left(\mathrm{CH}_{2}, \mathrm{C}-5^{\prime}\right), 60.4\left(\mathrm{CH}, \mathrm{C}-3^{\prime}\right), 38.0\left(\mathrm{CH}_{2}\right.$, $\left.\mathrm{C}-2^{\prime}\right), 25.9\left[\mathrm{CH}_{3}, \mathrm{SiC}\left(\mathrm{CH}_{3}\right)_{3}\right], 18.4\left[\mathrm{C}, \mathrm{SiC}\left(\mathrm{CH}_{3}\right)_{3}\right], 12.6\left(\mathrm{CH}_{3}\right.$, $\left.\mathrm{CH}_{3}-\mathrm{C}-5\right),-5.3\left[\mathrm{CH}_{3}, \mathrm{Si}\left(\mathrm{CH}_{3}\right)_{2}\right],-5.4\left[\mathrm{CH}_{3}, \mathrm{Si}\left(\mathrm{CH}_{3}\right)_{2}\right]$. One aromatic $\mathrm{CH}$ not seen. HRMS (ES+) $m / z$ calcd for $\mathrm{C}_{23} \mathrm{H}_{32} \mathrm{~N}_{5} \mathrm{O}_{5} \mathrm{Si}$ $[\mathrm{M}+\mathrm{H}]^{+}$486.2173, found 486.2187. $v_{\max } \mathrm{cm}^{-1}$ (film) 2929, 2103, $1750,1703,1662,1442,1256,1075,835,779$.

3'-Azido-3'-deoxy,3- $\mathbf{N}$-benzoylthymidine 54. Treatment of 53 $(1.90 \mathrm{~g}, 3.91 \mathrm{mmol})$ in THF $(24 \mathrm{~mL})$ and aqueous TFA $(12 \mathrm{~mL}$, 
TFA- $\mathrm{H}_{2} \mathrm{O}=1: 1$ ) by procedure $\mathrm{C}$ (chromatography using $\mathrm{CH}_{2} \mathrm{Cl}_{2} / \mathrm{MeOH}$ 98:2) afforded the product $\mathbf{5 4}$ as a white solid $(1.43 \mathrm{~g}, 98 \%) . \mathrm{mp}: 161-162^{\circ} \mathrm{C} . \delta_{\mathrm{H}}\left(300 \mathrm{MHz} ; \mathrm{CDCl}_{3}\right): 7.92(\mathrm{dd}$, $2 \mathrm{H}, J=7.2,1.5 \mathrm{~Hz}, \mathrm{ArH}_{\text {ortho }}$ ), 7.77 (finely split s, 1H, H-6), 7.67 (bt, $1 \mathrm{H}, J=7.5, \mathrm{ArH}_{\text {para }}$ ), $7.50\left(\mathrm{t}, 2 \mathrm{H}, J=8.1 \mathrm{~Hz}, \mathrm{ArH}_{\text {meta }}\right.$ ), $6.13\left(\mathrm{t}, 1 \mathrm{H}, J=6.3 \mathrm{~Hz}, \mathrm{H}-1^{\prime}\right), 4.34-4.27\left(\mathrm{~m}, 1 \mathrm{H}, \mathrm{H}-3^{\prime}\right)$, 3.94-3.84 (m, 2H, H-4', one of $\mathrm{H}^{-5^{\prime}}$ ), 3.70 (B part of ABX, $1 \mathrm{H}, J=12.0,2.4 \mathrm{~Hz}$, one of $\left.\mathrm{H}-5^{\prime}\right), 2.43-2.35\left(\mathrm{~m}, 2 \mathrm{H}, \mathrm{H}-2^{\prime}\right), 1.91$ (finely split s, $\left.3 \mathrm{H}, \mathrm{CH}_{3}\right) . \delta_{\mathrm{c}}\left(75 \mathrm{MHz} ; \mathrm{CDCl}_{3}\right): 169.1(\mathrm{C}), 163.1$ (C, C-4), 149.3 (C, C-2), 136.7 (CH, C-6), $135.4(\mathrm{CH}), 131.3(\mathrm{C})$, $130.4(\mathrm{CH}), 129.3(\mathrm{CH}), 110.9(\mathrm{C}, \mathrm{C}-5), 85.9\left(\mathrm{CH}, \mathrm{C}^{-1}{ }^{\prime}\right), 84.8$ $\left(\mathrm{CH}, \mathrm{C}-4^{\prime}\right), 61.7\left(\mathrm{CH}_{2}, \mathrm{C}-5^{\prime}\right), 60.1\left(\mathrm{CH}, \mathrm{C}-3^{\prime}\right), 37.7\left(\mathrm{CH}_{2}, \mathrm{C}-2^{\prime}\right)$, $12.6\left(\mathrm{CH}_{3}, \mathrm{CH}_{3}-\mathrm{C}-5\right)$. HRMS (ES+) $m / z$ calcd for $\mathrm{C}_{17} \mathrm{H}_{18} \mathrm{~N}_{5} \mathrm{O}_{5}$ $[\mathrm{M}+\mathrm{H}]^{+}$372.1308, found 372.1309. $v_{\max } \mathrm{cm}^{-1}$ (film) 3300, 2103, 1747, 1699, 1655, 1446, 1257, 1099, 763.

OH-Insertion Reaction of $3^{\prime}$-Azido-3'-deoxy, 3 - $N$-benzoylthymidine (54) and Trimethyldiazophosphonoacetate (20) to Give Phosphonate 55. Treatment of $54(1.43 \mathrm{~g}, 3.85 \mathrm{mmol})$ and $\mathbf{2 0}(880 \mathrm{mg}$, $4.23 \mathrm{mmol})$ with rhodium(II) acetate $(\sim 1 \mathrm{~mol} \%)$ by procedure D (chromatography using neat EtOAc) afforded the title product 55 as clear oil $(1.30 \mathrm{~g}, 61 \%)$. NMR shows roughly a $1: 1$ mixture of two epimers. $\delta_{\mathrm{H}}\left(400 \mathrm{MHz} ; \mathrm{CDCl}_{3}\right): 7.97-7.90\left(\mathrm{~m}, 2.5 \mathrm{H}, \mathrm{ArH}_{\text {ortho }}\right.$ 2 epimers, H-6 1 epimer), 7.71 (finely split s, 0.5H, H-6, 1 epimer), 7.62 (bt, $1 \mathrm{H}, J=7.2 \mathrm{~Hz}, \mathrm{ArH}_{\text {para }}, 2$ epimers), 7.47 (bt, $2 \mathrm{H}, J=7.8$ $\mathrm{Hz}, \mathrm{ArH}_{\text {meta }}, 2$ epimers), 6.32-6.23 (m, 1H, H-1', 2 epimers), $4.61-4.40$ (m, 1H, H-3', 2 epimers), 4.47 (d, 0.5H, $J=18.6 \mathrm{~Hz}$, $\mathrm{PCH}, 1$ epimer), 4.41 (d, $0.5 \mathrm{H}, J=18.3 \mathrm{~Hz}, \mathrm{PCH}, 1$ epimer), 4.10-3.74 (m, 12H, H-4', $2 \times \mathrm{H}-5^{\prime}, 9 \mathrm{x} \mathrm{CH}_{3}, 2$ epimers), 2.43-2.34 (m, 2H, H-2', 2 epimers), 2.00 (finely split s, $1.5 \mathrm{H}, \mathrm{CH}_{3}-\mathrm{C}-5$, 1 epimer), 1.97 (finely split s, $1.5 \mathrm{H}, \mathrm{CH}_{3}-\mathrm{C}-5,1$ epimer). $\delta \mathrm{c}(100$ $\mathrm{MHz} ; \mathrm{CDCl}_{3}$ ): 169.1 (C, NCOPh, 1 epimer), 169.1 (C, NCOPh, 1 epimer), 167.2 (C, d, $J=1.3 \mathrm{~Hz}, \mathrm{CO}_{2} \mathrm{Me}, 1$ epimer), 166.9 (C, d, $J=1.6 \mathrm{~Hz}, \mathrm{CO}_{2} \mathrm{Me}, 1$ epimer), 163.0 (C, C-4, 1 epimer), 162.9 (C, C-4, 1 epimer), 149.40 (C, C-2, 1 epimer), 149.37 (C, C-2, 1 epimer), $136.0(\mathrm{CH}, \mathrm{C}-6,1$ epimer $), 135.6(\mathrm{CH}, \mathrm{C}-6), 135.1\left(\mathrm{CH}, \mathrm{ArH}_{\text {para }}\right.$, 2 epimers), 131.53 (C, 1 epimer), 131.48 (C, 1 epimer), $130.4(\mathrm{CH})$, 129.2(CH), 111.8 (C, C-5, 1 epimer), 111.4 (C, C-5, 1 epimer), 85.0 (CH, C-1', 1 epimer), 84.4 (CH, C-1', 1 epimer), 82.9 (CH, C-4', 1 epimer), 82.8 (CH, C-4', 1 epimer), $76.0(\mathrm{CH}, \mathrm{d}, J=157.3 \mathrm{~Hz}$, PCH, 1 epimer), 75.6 (CH, d, $J=158.2 \mathrm{~Hz}, \mathrm{PCH}, 1$ epimer), 72.4 $\left(\mathrm{CH}_{2}, \mathrm{~d}, J=10.6 \mathrm{~Hz}, \mathrm{C}-5^{\prime}, 1\right.$ epimer $), 71.6\left(\mathrm{CH}_{2}, \mathrm{~d}, J=11.2 \mathrm{~Hz}\right.$, $\mathrm{C}-5^{\prime}, 1$ epimer), 61.6 ( $\mathrm{CH}, \mathrm{C}-3^{\prime}, 1$ epimer), 60.8 (CH, C-3', 1 epimer), 54.2-53.8 $\left[\mathrm{CH}_{3}, \mathrm{~m},\left(\mathrm{CH}_{3} \mathrm{O}\right)_{2} \mathrm{PO}, 2\right.$ epimers $], 53.10$ $\left(\mathrm{CH}_{3}, \mathrm{CO}_{2} \mathrm{CH}_{3}, 1\right.$ epimer $), 53.08\left(\mathrm{CH}_{3}, \mathrm{CO}_{2} \mathrm{CH}_{3}, 1\right.$ epimer $), 37.6$ $\left(\mathrm{CH}_{2}, \mathrm{C}-2^{\prime}, 1\right.$ epimer $), 37.3\left(\mathrm{CH}_{2}, \mathrm{C}-2^{\prime}, 1\right.$ epimer $), 12.10\left(\mathrm{CH}_{3}\right.$, $\mathrm{CH}_{3}-\mathrm{C}-5,1$ epimer $), 11.97\left(\mathrm{CH}_{3}, \mathrm{CH}_{3}-\mathrm{C}-5,1\right.$ epimer $) . \delta_{\mathrm{P}}(121$ $\left.\mathrm{MHz} ; \mathrm{CDCl}_{3}\right): 16.51$ (1 epimer), 16.25 (1 epimer). HRMS ( $\left.\mathrm{ES}^{+}\right)$ $m / z$ calcd for $\mathrm{C}_{22} \mathrm{H}_{27} \mathrm{~N}_{5} \mathrm{O}_{10} \mathrm{P}[\mathrm{M}+\mathrm{H}]^{+} 552.1496$, found 552.1496 . $[\alpha]_{\mathrm{D}} 34.87\left(\mathrm{c}=0.75, \mathrm{CHCl}_{3}, 20^{\circ} \mathrm{C}\right) . v_{\max } \mathrm{cm}^{-1}$ (film) 2956, 2101, 1747, 1701, 1658, 1441, 1259, 1032, 763.

Partial Deprotection of 55 to Give Phosphonate 56. Treatment of the phosphonate $\mathbf{5 5}(570 \mathrm{mg}, 1.03 \mathrm{mmol})$ by procedure $\mathrm{E}$ with TMSBr $(0.67 \mathrm{~mL}, 5.17 \mathrm{mmol})$ in dichloromethane $(20 \mathrm{~mL})$ for $2 \mathrm{~h}$ then treatment with water $(20 \mathrm{~mL})$ and $\mathrm{NaOH}(1 \mathrm{M}, 1.5 \mathrm{~mL}$, 1.4 equiv) overnight at room temperature afforded, after charcoal column $(\mathrm{pH} \approx 3.0$ before adsorption, elution with ethanol/ $\left.\mathrm{H}_{2} \mathrm{O} / \mathrm{NH}_{4} \mathrm{OH}, 10: 10: 3\right)$, the methyl ester as its ammonium salt $56(270 \mathrm{mg}, 60 \%)$. NMR shows roughly a 1.2: 1 mixture of two epimers. $\delta_{\mathrm{H}}\left(400 \mathrm{MHz} ; \mathrm{D}_{2} \mathrm{O}\right): 7.61(\mathrm{~s}, 0.55 \mathrm{H}, \mathrm{H}-6$, major epimer), 7.42 (s, 0.45H, H-6, minor epimer), 6.08-5.98 (m, $1 \mathrm{H}, \mathrm{H}-1^{\prime}, 2$ epimers), $4.38-4.29$ ( $\mathrm{m}, 0.55 \mathrm{H}, \mathrm{H}-3^{\prime}$, major epimer), 4.25-4.16 (m, 0.45H, H-3', minor epimer), 4.07 (bd, $1 \mathrm{H}, J=$ $17.4 \mathrm{~Hz}, \mathrm{PCH}, 2$ epimers), 4.01-3.96 ( $\mathrm{m}, 1 \mathrm{H}, \mathrm{H}-4^{\prime}, 2$ epimers), 3.73-3.47 (m, $2 \mathrm{H}, 2 \times \mathrm{H}-5^{\prime}, 2$ epimers), 3.58 (bs, $3 \mathrm{H}, \mathrm{CO}_{2} \mathrm{CH}_{3}$, 2 epimers), 2.44-2.18 (m, 2H, H-2', 2 epimers), 1.72 (s, $1.45 \mathrm{H}$, $\mathrm{CH}_{3}-\mathrm{C}-5$, minor epimer), $1.70\left(\mathrm{~s}, 1.55 \mathrm{H}, \mathrm{CH}_{3}-\mathrm{C}-5\right.$, major epimer). $\delta \mathrm{c}\left(100 \mathrm{MHz} ; \mathrm{D}_{2} \mathrm{O}\right): 172.8\left(\mathrm{C}, \mathrm{CO}_{2} \mathrm{Me}\right.$, minor epimer), 172.4 (C, $\mathrm{CO}_{2} \mathrm{Me}$, major epimer), 166.4 (C, C-4, major epimer),
166.3 (C, C-4, minor epimer), 151.4 (C, C-2, 2 epimers), 137.7 (CH, C-6, major epimer), 137.4 (CH, C-6, minor epimer), 111.55 (C, C-5, minor epimer), 111.48 (C, C-5, major epimer), 85.13 (CH, C-1', minor epimer), 85.09 (CH, C-1', major epimer), 82.9 ( $\mathrm{CH}, \mathrm{C}-4^{\prime}$, major epimer), 82.5 ( $\mathrm{CH}, \mathrm{C}-4^{\prime}$, minor epimer), $79.7(\mathrm{CH}, \mathrm{d}, J=133.0 \mathrm{~Hz}, \mathrm{PCH}$, minor epimer), $79.3(\mathrm{CH}, \mathrm{d}, J=$ 135.3 Hz, PCH, major epimer), 71.9-71.7 ( $\mathrm{CH}_{2}, \mathrm{~m}, \mathrm{C}-5^{\prime}, 2$ epimers), 61.1 (CH, C-3', major epimer), 60.4 ( $\mathrm{CH}, \mathrm{C}-3^{\prime}$, minor epimer), $52.4\left(\mathrm{CH}_{3}, \mathrm{CO}_{2} \mathrm{CH}_{3}, 2\right.$ epimers $), 36.0\left(\mathrm{CH}_{2}, \mathrm{C}-2^{\prime}\right.$, major epimer $)$, $35.5\left(\mathrm{CH}_{2}, \mathrm{C}-2^{\prime}\right.$, minor epimer $), 11.5\left(\mathrm{CH}_{3}, \mathrm{CH}_{3}-\mathrm{C}-5\right.$, minor epimer), $11.4\left(\mathrm{CH}_{3}, \mathrm{CH}_{3}-\mathrm{C}-5\right.$, major epimer $) . \delta_{\mathrm{P}}(161 \mathrm{MHz}$; $\left.\mathrm{D}_{2} \mathrm{O}\right): 11.54$ (2 epimers). HRMS $\left(\mathrm{ES}^{+}\right) \mathrm{m} / z$ calcd for $\mathrm{C}_{13} \mathrm{H}_{19} \mathrm{~N}_{5^{-}}$ $\mathrm{O}_{9} \mathrm{P}[\mathrm{M}+\mathrm{H}]^{+} 420.0920$, found 420.0930. $v_{\max } \mathrm{cm}^{-1}$ (film) 3208, 2107, 1697, 1439, 1275, 1070, 912, 766, 557. HPLC 3.48 and $4.22 \mathrm{~min}$ ( 2 epimers), $96.8 \%$.

Full Deprotection of 55 to Give Phosphonate 57. Treatment of the phosphonate $55(590 \mathrm{mg}, 1.07 \mathrm{mmol})$ by procedure $\mathrm{E}$ with $\operatorname{TMSBr}(0.67 \mathrm{~mL}, 5.17 \mathrm{mmol})$ in dichloromethane $(20 \mathrm{~mL})$ for $2 \mathrm{~h}$ then treatment with water $(20 \mathrm{~mL})$ and $\mathrm{NaOH}(1 \mathrm{M}, 10 \mathrm{~mL}$, 9.3 equiv) overnight at room temperature afforded, after charcoal column $(\mathrm{pH} \approx 2.5$ before adsorption, elution with a solution of $20 \% \mathrm{NH}_{4} \mathrm{OH}$ ), the fully deprotected phosphonate as its ammonium salt 57 (310 mg, 69\%). NMR shows roughly a 1.2: 1 mixture of two epimers. $\delta_{\mathrm{H}}\left(600 \mathrm{MHz} ; \mathrm{D}_{2} \mathrm{O}\right): 7.59(\mathrm{~s}, 0.55 \mathrm{H}, \mathrm{H}-6$, major epimer), 7.50 (s, 0.45H, H-6, minor epimer), 6.16-6.6.08 (m, $1 \mathrm{H}$, $\mathrm{H}-1^{\prime}, 2$ epimers), 4.38-4.31 (m, 1H, H-3', 2 epimers), 4.12-4.03 (m, 1H, H-4', 2 epimers), 3.95-3.48 ( $\mathrm{m}, 3 \mathrm{H}, \mathrm{PCH}, \mathrm{H}-5^{\prime}, 2$ epimers), 2.49-2.31 (m, 2H, H-2', 2 epimers), 1.81 (s, $1.45 \mathrm{H}, \mathrm{CH}_{3}-\mathrm{C}-5$, minor epimer), 1.80 (s, $1.55 \mathrm{H}, \mathrm{CH}_{3}-\mathrm{C}-5$, major epimer). $\delta \mathrm{c}(100$ $\mathrm{MHz} ; \mathrm{D}_{2} \mathrm{O}$ ): 166.47 (C, C-4, 1 epimer), 166.44 (C, C-4, 1 epimer), 151.6 (C, C-2, 2 epimers), 137.7 (CH, C-6, major epimer), 137.4 (CH, C-6, minor epimer), 111.8 (C, C-5, 2 epimers), 85.11 ( $\mathrm{CH}$, C-1', major epimer), 85.04 (CH, C-1', minor epimer), $83.0(\mathrm{CH}$, C-4', major epimer), 82.6 (CH, C-4', minor epimer), 71.7-71.2 $\left(\mathrm{CH}_{2}, \mathrm{~m}, \mathrm{C}-5^{\prime}, 2\right.$ epimers), 60.8 (CH, C-3' , major epimer), $60.5(\mathrm{CH}$, C-3', minor epimer), $35.7\left(\mathrm{CH}_{2}, \mathrm{C}-2^{\prime}\right.$, major epimer $), 35.6\left(\mathrm{CH}_{2}\right.$, $\mathrm{C}-2^{\prime}$, minor epimer), $11.53\left(\mathrm{CH}_{3}, \mathrm{CH}_{3}-\mathrm{C}-5\right.$, minor epimer $), 11.51$ $\left(\mathrm{CH}_{3}, \mathrm{CH}_{3}-\mathrm{C}-5\right.$, major epimer). PCH could not be detected. $\delta_{\mathrm{P}}\left(161 \mathrm{MHz} ; \mathrm{D}_{2} \mathrm{O}\right): 11.77$ (2 epimers). HRMS $\left(\mathrm{ES}^{+}\right) \mathrm{m} / z$ calcd for $\mathrm{C}_{12} \mathrm{H}_{17} \mathrm{~N}_{5} \mathrm{O}_{9} \mathrm{P}[\mathrm{M}+\mathrm{H}]^{+}$406.0764, found 406.0724. $v_{\max } \mathrm{cm}^{-1}$ (film) 3216, 2109, 1697, 1595, 1433, 1274, 1069, 911, 766, 560. HPLC 1.50 min (2 epimers), $99.9 \%$.

Monophosphorylation. Preparation of Tributylammonium Orthophosphate. ${ }^{37}$ Anhydrous othophosphoric acid (7.5 g, $77 \mathrm{mmol}$ ) was added to $50 \mathrm{~mL}$ of anhydrous $\mathrm{CH}_{2} \mathrm{Cl}_{2}$ in a $100 \mathrm{~mL}$ flask. Tributylamine $(18.3 \mathrm{~mL}, 77 \mathrm{mmol}$ ) was then added dropwise to the solution through an addition funnel over a period of $30 \mathrm{~min}$ under anhydrous conditions. The mixture was left stirring for $1 \mathrm{~h} . \mathrm{CH}_{2} \mathrm{Cl}_{2}$ was then evaporated, and the reaction residue was coevaporated with DMF $(2 \times 20 \mathrm{~mL})$. The final product was dissolved in $77 \mathrm{~mL}$ of anhydrous $\mathrm{DMF}$, so as to have a final concentration of $1 \mathrm{M}$ and stored over molecular sieves at $4{ }^{\circ} \mathrm{C}$.

Monophosphorylation of $\mathbf{5 6}$ to Give $\mathbf{5 8}$. The compound $\mathbf{5 6}$ was converted to the triethylammonium salt by evaporation from $50 \mathrm{~mL}$ of a solution of $100 \mathrm{mM}$ triethylammonium bicarbonate (2 times). Residual water was removed by coevaporation with acetonitrile. Then, the triethylammonium salt 56 (103 mg, $0.26 \mathrm{mmol})$ was dissolved in anhydrous DMF (10 mL). 1,1'-Carbonyldiimidazole (CDI) (250 mg, $1.54 \mathrm{mmol}$ ) was added and the reaction mixture was stirred at room temperature for $5 \mathrm{~h}$. Methanol $(3.08 \mathrm{mmol}, 0.12 \mathrm{~mL})$ was then added to hydrolyze the excess of CDI and stirring was continued for $30 \mathrm{~min}$. A solution of tributylammonium phosphate in DMF (1 M solution in anhydrous DMF) $(1.54 \mathrm{~mL}, 1.54 \mathrm{mmol})$ was added and stirring was continued overnight at room temperature. The reaction was terminated by addition of water $(20 \mathrm{~mL})$ and the reaction mixture was directly applied to a column of DEAE Sephadex A-25 (2 g) that had been equilibrated in $50 \mathrm{mM}$ ammonium bicarbonate. The column was eluted with $250 \mathrm{~mL}$ of $50 \mathrm{mM}$ 
ammonium bicarbonate followed by $250 \mathrm{~mL}$ of $100 \mathrm{mM}$ ammonium bicarbonate and then $100 \mathrm{~mL}$ of $500 \mathrm{mM}$ ammonium bicarbonate. The product elutes with the $500 \mathrm{mM}$ ammonium bicarbonate solution. The fractions containing the product were combined and dried in vacuo. The product was lyophilized to give $\mathbf{5 8}$ as a fine white solid ( $m=94 \mathrm{mg}, 71 \%$ ).

${ }^{1} \mathrm{H}$ and ${ }^{13} \mathrm{C}$ NMR show roughly a $1.2: 1$ mixture of two epimers. $\delta_{\mathrm{H}}\left(600 \mathrm{MHz} ; \mathrm{D}_{2} \mathrm{O}\right): 7.86$ (s, $0.55 \mathrm{H}, \mathrm{H}-6$, major epimer), 7.56 (s, $0.45 \mathrm{H}, \mathrm{H}-6$, minor epimer), $6.21-6.10\left(\mathrm{~m}, 1 \mathrm{H}, \mathrm{H}^{-1}{ }^{\prime}, 2\right.$ epimers), $4.62-4.34$ ( $\mathrm{m}, 2 \mathrm{H}, \mathrm{H}-3^{\prime}, \mathrm{H}-4^{\prime}, 2$ epimers), 4.10-3.76 (m, 2H, $2 \times$ $\mathrm{H}-5^{\prime}, 2$ epimers), 3.67 (s, $1.45 \mathrm{H}, \mathrm{CO}_{2} \mathrm{CH}_{3}$, minor epimer), 3.66 (s, $1.55 \mathrm{H}, \mathrm{CO}_{2} \mathrm{CH}_{3}$, major epimer), 2.52-2.28 (m, 2H, H-2', 2 epimers), 1.81 (s, $1.45 \mathrm{H}, \mathrm{CH}_{3}-\mathrm{C}-5$, minor epimer), $1.78(\mathrm{~s}, 1.55 \mathrm{H}$, $\mathrm{CH}_{3}-\mathrm{C}-5$, major epimer), $\mathrm{PCH}$ not seen. $\delta \mathrm{c}\left(100 \mathrm{MHz} ; \mathrm{D}_{2} \mathrm{O}\right)$ : $171.7\left(\mathrm{C}, \mathrm{CO}_{2} \mathrm{Me}\right.$, minor epimer), $171.5\left(\mathrm{C}, \mathrm{CO}_{2} \mathrm{Me}\right.$, major epimer), 166.6 (C, C-4, major epimer), 166.5 (C, C-4, minor epimer), 151.8 (C, C-2, major epimer), 151.6 (C, C-2, minor epimer), $138.0(\mathrm{CH}$, C-6, major epimer), 137.5 (CH, C-6, minor epimer), 111.7 (C, C-5, 2 epimers), 85.10 ( $\mathrm{CH}, \mathrm{C}-1^{\prime}$, minor epimer), 84.98 ( $\mathrm{CH}, \mathrm{C}-1^{\prime}$, major epimer), 83.3 ( $\mathrm{CH}, \mathrm{C}-4^{\prime}$, major epimer), 82.7 ( $\mathrm{CH}, \mathrm{C}-4^{\prime}$, minor epimer), 72.0-71.8 ( $\mathrm{m}, \mathrm{CH}_{2}, \mathrm{C}-5^{\prime}, 2$ epimers), 61.8 (CH, C-3' , major epimer), $60.6\left(\mathrm{CH}, \mathrm{C}-3^{\prime}\right.$, minor epimer), $52.7\left(\mathrm{CH}_{3}, \mathrm{CO}_{2} \mathrm{CH}_{3}\right.$, minor epimer), $52.6\left(\mathrm{CH}_{3}, \mathrm{CO}_{2} \mathrm{CH}_{3}\right.$, major epimer $), 36.4\left(\mathrm{CH}_{2}, \mathrm{C}-2^{\prime}\right.$, major epimer), $35.7\left(\mathrm{CH}_{2}, \mathrm{C}-2^{\prime}\right.$, minor epimer $), 11.5\left(\mathrm{CH}_{3}, \mathrm{CH}_{3}-\mathrm{C}-5\right.$, minor epimer), $11.4\left(\mathrm{CH}_{3}, \mathrm{CH}_{3}-\mathrm{C}-5\right.$, major epimer), $\mathrm{PCH}$ not seen. $\delta_{\mathrm{P}}\left(161 \mathrm{MHz} ; \mathrm{D}_{2} \mathrm{O}\right):-0.24--0.20$ (m, 2 epimers), $-7.69--7.65$ (m, 2 epimers). HRMS (ES $\left.{ }^{+}\right) m / z$ calcd for $\mathrm{C}_{13} \mathrm{H}_{20} \mathrm{~N}_{5} \mathrm{O}_{12} \mathrm{P}_{2}[\mathrm{M}+$ $\mathrm{H}]^{+}$500.0584, found 500.0581. $v_{\max } \mathrm{cm}^{-1}$ (film) 3218, 3063, 2108, 1697, 1442, 1227, 1079, 912, 490.

Monophosphorylation of 56 to Give 59. The compound 56 was converted to the triethylammonium salt by evaporation from $50 \mathrm{~mL}$ of a solution of $100 \mathrm{mM}$ triethylammonium bicarbonate ( 2 times). Residual water was removed by coevaporation with acetonitrile. Then, the triethylammonium salt $\mathbf{5 6}(90 \mathrm{mg}, 0.23$ $\mathrm{mmol}$ ) was dissolved in anhydrous DMF $(10 \mathrm{~mL}) .1,1^{\prime}$-Carbonyldiimidazole (CDI) (224 mg, $1.38 \mathrm{mmol}$ ) was added and the reaction mixture was stirred at room temperature for $5 \mathrm{~h}$. Methanol $(2.76 \mathrm{mmol}, 0.11 \mathrm{~mL}$ ) was then added to hydrolyze the excess of CDI and stirring was continued for $30 \mathrm{~min}$. A solution of tributylammonium phosphate in DMF (1 M solution in anhydrous DMF) $(1.38 \mathrm{~mL}, 1.38 \mathrm{mmol})$ was added and stirring was continued overnight at room temperature. The reaction was terminated by addition of water $(20 \mathrm{~mL})$, then, a solution of $\mathrm{NaOH}$ was added in excess $(1 \mathrm{M}, 5 \mathrm{~mL})$, and the mixture was stirred overnight at room temperature. Then the mixture was directly applied to a column of DEAE Sephadex A-25 (2 g) that had been equilibrated in $50 \mathrm{mM}$ ammonium bicarbonate. The column was eluted with $250 \mathrm{~mL}$ of 50 $\mathrm{mM}$ ammonium bicarbonate followed by $250 \mathrm{~mL}$ of $100 \mathrm{mM}$ ammonium bicarbonate and then $100 \mathrm{~mL}$ of $500 \mathrm{mM}$ ammonium bicarbonate. The fractions containing the product were combined and dried in vacuo. The product was lyophilized to give $\mathbf{5 9}$ as a fine white solid ( $m=72 \mathrm{mg}, 64 \%$ ).

${ }^{1} \mathrm{H}$ and ${ }^{13} \mathrm{C}$ NMR show roughly a 1.2: 1 mixture of two epimers. $\delta_{\mathrm{H}}\left(600 \mathrm{MHz} ; \mathrm{D}_{2} \mathrm{O}\right): 7.71$ (s, $0.45 \mathrm{H}, \mathrm{H}-6$, minor epimer), 7.52 (s, 0.55H, H-6, major epimer), 6.19-6.06 (m, 1H, H-1', 2 epimers), $4.50-4.32$ ( $\mathrm{m}, 1 \mathrm{H}, \mathrm{H}-3^{\prime}, 2$ epimers), $4.18-4.02(\mathrm{~m}, 1 \mathrm{H}$, $\mathrm{H}-4^{\prime}, 2$ epimers), $3.82-3.62$ ( $\mathrm{m}, 2 \mathrm{H}, 2 \times \mathrm{H}-5^{\prime}, 2$ epimers), 2.482.29 (m, 2H, H-2', 2 epimers), 1.81 (s, $1.55 \mathrm{H}, \mathrm{CH}_{3}-\mathrm{C}-5$, major epimer), 1.79 (s, $1.45 \mathrm{H}, \mathrm{CH}_{3}-\mathrm{C}-5$, minor epimer), $\mathrm{PCH}$ not seen. $\delta \mathrm{c}\left(100 \mathrm{MHz} ; \mathrm{D}_{2} \mathrm{O}\right)$ : 166.6 (C, C-4, minor epimer), 166.5 (C, C-4, major epimer), 151.7 (C, C-2, minor epimer), 151.6 (C, C-2, major epimer), 137.8 ( $\mathrm{CH}, \mathrm{C}-6$, minor epimer), 137.4 ( $\mathrm{CH}, \mathrm{C}-6$, major epimer), 111.8 (C, C-5, 2 epimers), 84.9 ( $\mathrm{CH}, \mathrm{C}-1^{\prime}, 2$ epimers), 83.1 ( $\mathrm{CH}, \mathrm{C}-4^{\prime}$, major epimer), $82.6\left(\mathrm{CH}, \mathrm{C}-4^{\prime}\right.$, minor epimer), 71.6-71.3 (m, $\mathrm{CH}_{2}, \mathrm{C}-5^{\prime}, 2$ epimers), $61.3\left(\mathrm{CH}, \mathrm{C}-3^{\prime}\right.$, minor epimer), 60.7 ( $\mathrm{CH}, \mathrm{C}-3^{\prime}$, major epimer), $36.0\left(\mathrm{CH}_{2}, \mathrm{C}-2^{\prime}\right.$, minor epimer), $35.6\left(\mathrm{CH}_{2}, \mathrm{C}-2^{\prime}\right.$, major epimer $), 11.5\left(\mathrm{CH}_{3}, \mathrm{CH}_{3}-\mathrm{C}-5\right.$, 2 epimers), $\mathrm{CO}_{2} \mathrm{H}$ and $\mathrm{PCH}$ not seen. $\delta_{\mathrm{P}}\left(161 \mathrm{MHz} ; \mathrm{D}_{2} \mathrm{O}\right)$ :
2.98-2.91 (m, 2 epimers), $-10.14--10.22$ (m, 2 epimers). HRMS $\left(\mathrm{ES}^{+}\right) m / z$ calcd for $\mathrm{C}_{12} \mathrm{H}_{18} \mathrm{~N}_{5} \mathrm{O}_{12} \mathrm{P}_{2}[\mathrm{M}+\mathrm{H}]^{+} 486.0427$, found 486.0427. $v_{\max } \mathrm{cm}^{-1}$ (film) 3203, 2109, 1697, 1594, 1442, $1213,1069,911,492$.

Diphosphorylation of 56 to Give 60. The compound 56 was converted to the triethylammonium salt by evaporation from $50 \mathrm{~mL}$ of a solution of $100 \mathrm{mM}$ triethylammonium bicarbonate ( 2 times). Residual water was removed by coevaporation with acetonitrile. Then, the triethylammonium salt $\mathbf{5 6}$ (140 mg, 0.35 mmol) was dissolved in $20 \mathrm{~mL}$ of DMF. 1, 1'-Carbonyldiimidazole (339 mg, $2.09 \mathrm{mmol}$ ) was added and the reaction mixture was stirred at room temperature overnight. Methanol (4.18 mmol, $0.17 \mathrm{~mL}$ ) was then added and stirring was continued for $35 \mathrm{~min}$. Tributylammonium pyrophosphate $(1.15 \mathrm{~g}, 2.09$ $\mathrm{mmol}$ ) was added and stirring was continued overnight at room temperature. The reaction was terminated by addition of water $(20 \mathrm{~mL})$, then the mixture was directly applied to a column of DEAE Sephadex A-25 (2 g) that had been equilibrated in $50 \mathrm{mM}$ ammonium bicarbonate. The column was eluted with $250 \mathrm{~mL}$ of $50 \mathrm{mM}$ ammonium bicarbonate followed by $250 \mathrm{~mL}$ of $100 \mathrm{mM}$ ammonium bicarbonate and then $100 \mathrm{~mL}$ of $500 \mathrm{mM}$ ammonium bicarbonate. The fractions containing the product were combined and dried in vacuo to give after lyophilization $\mathbf{6 0}$ as a white solid (120 mg, 58\%). ${ }^{1} \mathrm{H}$ and ${ }^{13} \mathrm{C}$ NMR show roughly a 1.8: 1 mixture of two epimers. $\delta_{\mathrm{H}}\left(600 \mathrm{MHz} ; \mathrm{D}_{2} \mathrm{O}\right): 7.87(\mathrm{~s}, 0.65$ $\mathrm{H}, \mathrm{H}-6$, major epimer), 7.54 (s, $0.35 \mathrm{H}, \mathrm{H}-6$, minor epimer), 6.22-6.18 (m, 0.65H, H-1', major epimer), 6.15-6.11 (m, $0.35 \mathrm{H}, \mathrm{H}-1^{\prime}$, minor epimer), $4.61-4.58\left(\mathrm{~m}, 0.35 \mathrm{H}, \mathrm{H}-3^{\prime}\right.$, minor epimer), 4.50 (d, $0.35 \mathrm{H}, J=18.0 \mathrm{~Hz}, \mathrm{PCH}$, minor epimer), 4.49 $(\mathrm{d}, 0.65 \mathrm{H}, J=18.0 \mathrm{~Hz}, \mathrm{PCH}$, major epimer $), 4.37-4.32(\mathrm{~m}$, $0.65 \mathrm{H}, \mathrm{H}-3^{\prime}$, major epimer), $4.12-4.06$ ( $\mathrm{m}, 1 \mathrm{H}, \mathrm{H}-4^{\prime}, 2$ epimers), $3.93-3.64\left(\mathrm{~m}, 2 \mathrm{H}, 2 \times \mathrm{H}-5^{\prime}, 2\right.$ epimers), 3.69 (s, $3 \mathrm{H}, \mathrm{CO}_{2} \mathrm{CH}_{3}$, 2 epimers), 2.52-2.28 (m, 2H, H-2', 2 epimers), 1.80 (s, $1.05 \mathrm{H}$, $\mathrm{CH}_{3}-\mathrm{C}-5$, minor epimer), $1.78\left(\mathrm{~s}, 1.95 \mathrm{H}, \mathrm{CH}_{3}-\mathrm{C}-5\right.$, major epimer). $\delta c\left(150 \mathrm{MHz} ; \mathrm{D}_{2} \mathrm{O}\right)$ : $171.9\left(\mathrm{C}, \mathrm{CO}_{2} \mathrm{Me}, 2\right.$ epimers), 166.6 (C, C-4, 2 epimers), 151.8 (C, C-2, 2 epimers), 137.9 (CH, C-6, major epimer), 137.4 (CH, C-6, minor epimer), 111.7 (C, C-5, 2 epimers), 84.9 ( $\mathrm{CH}, \mathrm{C}-1^{\prime}, 2$ epimers), 83.2 (CH, C-4', 2 epimers), $72.0-71.8$ ( $\mathrm{m}, \mathrm{CH}_{2}, \mathrm{C}-5^{\prime}, 2$ epimers), 61.9 ( $\mathrm{CH}, \mathrm{C}-3^{\prime}$, major epimer), $60.6\left(\mathrm{CH}, \mathrm{C}-3^{\prime}\right.$, minor epimer), $52.8\left(\mathrm{CH}_{3}\right.$, $\mathrm{CO}_{2} \mathrm{CH}_{3}$, minor epimer), $52.7\left(\mathrm{CH}_{3}, \mathrm{CO}_{2} \mathrm{CH}_{3}\right.$, major epimer), $36.3\left(\mathrm{CH}_{2}, \mathrm{C}-2^{\prime}\right.$, major epimer $), 35.7\left(\mathrm{CH}_{2}, \mathrm{C}-2^{\prime}\right.$, minor epimer $)$, $11.5\left(\mathrm{CH}_{3}, \mathrm{CH}_{3}-\mathrm{C}-5\right.$, minor epimer $), 11.4\left(\mathrm{CH}_{3}, \mathrm{CH}_{3}-\mathrm{C}-5\right.$, major epimer), $\mathrm{PCH}$ not seen. $\delta_{\mathrm{P}}\left(161 \mathrm{MHz} ; \mathrm{D}_{2} \mathrm{O}\right):-8.25(\alpha-\mathrm{P}$ and $\gamma$-P, 2 epimers), -22.18 ( $\beta$-P, 2 epimers). HRMS (ES $\left.{ }^{+}\right) m / z$ calcd for $\mathrm{C}_{13} \mathrm{H}_{21} \mathrm{~N}_{5} \mathrm{O}_{15} \mathrm{P}_{3}[\mathrm{M}+\mathrm{H}]^{+} 580.0247$, found 580.0253 .

Diphosphorylation of 56 to Give 61. The compound 56 was converted to the triethylammonium salt by evaporation from $50 \mathrm{~mL}$ of a solution of $100 \mathrm{mM}$ triethylammonium bicarbonate (2 times). Residual water was removed by coevaporation with acetonitrile. Then, the triethylammonium salt $\mathbf{5 6}(140 \mathrm{mg}, 0.35$ mmol) was dissolved in $20 \mathrm{~mL}$ of DMF. 1, 1'-Carbonyldiimidazole $(339 \mathrm{mg}, 2.09 \mathrm{mmol})$ was added and the reaction was stirred at room temperature for $5 \mathrm{~h}$. Methanol (4.18 mmol, $0.17 \mathrm{~mL}$ ) was then added and stirring was continued at room temperature for $30 \mathrm{~min}$. Tributylammonium pyrophosphate $(1.15 \mathrm{~g}, 2.09$ mmol) was added and stirring was continued overnight at room temperature. The reaction was terminated by addition of water $(20 \mathrm{~mL})$ and a solution of $\mathrm{NaOH}(1 \mathrm{M}, 5 \mathrm{~mL})$ in excess was added, and the mixture was stirred overnight at room temperature. Then the mixture was directly applied to a column of DEAE Sephadex A-25 (2 g) that had been equilibrated in $50 \mathrm{mM}$ ammonium bicarbonate. The column was eluted with $250 \mathrm{~mL}$ of $50 \mathrm{mM}$ ammonium bicarbonate followed by $250 \mathrm{~mL}$ of $100 \mathrm{mM}$ ammonium bicarbonate and then $100 \mathrm{~mL}$ of $500 \mathrm{mM}$ ammonium bicarbonate. The fractions containing the product were combined and dried in vacuo. The product was lyophilized to give 61 as a solid ( $m=170 \mathrm{mg}, 84 \%$ ). 
${ }^{1} \mathrm{H}$ and ${ }^{13} \mathrm{C}$ NMR shows roughly a 1.2: 1 mixture of two epimers. $\delta_{\mathrm{H}}\left(400 \mathrm{MHz} ; \mathrm{D}_{2} \mathrm{O}\right): 7.49$ (s, $0.45 \mathrm{H}, \mathrm{H}-6$, minor epimer), 7.33 (s, 0.55H, H-6, major epimer), 6.04-5.91 (m, 1H, H-1', 2 epimers), $4.32-4.12$ ( $\mathrm{m}, 1 \mathrm{H}, \mathrm{H}-3^{\prime}, 2$ epimers), $4.00-3.86$ (m, $2 \mathrm{H}$, $\mathrm{PCH}, \mathrm{H}-4^{\prime}, 2$ epimers), 3.67-3.35 (m, 2H, $2 \times \mathrm{H}-5^{\prime}, 2$ epimers), 2.35-2.16 (m, 2H, H-2', 2 epimers), 1.65 (s, 3H, $\mathrm{CH}_{3}-\mathrm{C}-5$, 2 epimers). $\delta \mathrm{c}\left(100 \mathrm{MHz} ; \mathrm{D}_{2} \mathrm{O}\right): 174.7\left(\mathrm{C}, \mathrm{CO}_{2} \mathrm{H}, 2\right.$ epimers), 166.42 (C, C-4, minor epimer), 166.37 (C, C-4, major epimer), 151.57 (C, C-2, minor epimer), 151.52 (C, C-2, major epimer), 137.6 ( $\mathrm{CH}, \mathrm{C}-6$, minor epimer), 137.2 ( $\mathrm{CH}, \mathrm{C}-6$, major epimer), 111.7 (C, C-5, 2 epimers), 85.0 (CH, C-1' ${ }^{\prime}$, minor epimer), $84.8(\mathrm{CH}$, $\mathrm{C}-1^{\prime}$, major epimer), 82.9 ( $\mathrm{CH}, \mathrm{C}-4^{\prime}$, minor epimer), $82.4(\mathrm{CH}$, C-4', major epimer), $80.3(\mathrm{CH}, \mathrm{d}, J=138.0 \mathrm{~Hz}, \mathrm{PCH}$, major epimer), 80.2 (CH, d, $J=135.3 \mathrm{~Hz}, \mathrm{PCH}$, minor epimer), 71.571.4 ( $\mathrm{m}, \mathrm{CH}_{2}, \mathrm{C}-5^{\prime}, 2$ epimers), 60.9 (CH, C-3', minor epimer), 60.4 (CH, C-3', major epimer), $35.6\left(\mathrm{CH}_{2}, \mathrm{C}-2^{\prime}\right.$, minor epimer $), 35.4$ $\left(\mathrm{CH}_{2}, \mathrm{C}-2^{\prime}\right.$, major epimer $), 11.4\left(\mathrm{CH}_{3}, \mathrm{CH}_{3}-\mathrm{C}-5,2\right.$ epimers $)$. $\delta_{\mathrm{P}}\left(161 \mathrm{MHz} ; \mathrm{D}_{2} \mathrm{O}\right):-8.14(\alpha-\mathrm{P}$ and $\gamma$-P, 2 epimers $),-8.54(\beta-\mathrm{P}$, 2 epimers), -22.04 (2 epimers). HRMS ( $\left.\mathrm{ES}^{+}\right) \mathrm{m} / z$ calcd for $\mathrm{C}_{12} \mathrm{H}_{19} \mathrm{~N}_{5} \mathrm{O}_{15} \mathrm{P}_{3}[\mathrm{M}+\mathrm{H}]^{+}$566.0091, found 566.0091. $v_{\max } \mathrm{cm}^{-1}$ (film) 3428, 2113, 1705, 1460, 1225, 1087, 896, 527.

Antiviral Activity Assays. The compounds were evaluated against the following viruses: herpes simplex virus type 1 (HSV-1) strain KOS, thymidine kinase-deficient ( $\mathrm{TK}^{-}$) $\mathrm{HSV}-1$ $\mathrm{KOS}$ strain resistant to $\mathrm{ACV}\left(\mathrm{ACV}^{\mathrm{r}}\right)$, herpes simplex virus type 2 (HSV-2) strains Lyons and G, varicella-zoster virus (VZV) strain Oka, TK ${ }^{-}$VZV strain 07-1, human cytomegalovirus (HCMV) strains AD-169 and Davis, vaccinia virus Lederle strain, respiratory syncytial virus (RSV) strain Long, vesicular stomatitis virus (VSV), Coxsackie B4, Parainfluenza 3, Reovirus-1, Sindbis, Reovirus-1, Punta Toro, human immunodeficiency virus type 1 strain IIIB and human immunodeficiency virus type 2 strain ROD, and Moloney murine sarcoma virus (MSV). The antiviral, other than anti-HIV, assays were based on inhibition of virus-induced cytopathicity or plaque formation in human embryonic lung (HEL) fibroblasts, African green monkey cells (Vero), human epithelial cells (HeLa). Confluent cell cultures in microtiter 96-well plates were inoculated with $100 \mathrm{CCID}_{50}$ of virus $\left(1 \mathrm{CCID}_{50}\right.$ being the virus dose to infect $50 \%$ of the cell cultures) or with 20 plaque forming units (PFU) (VZU) in the presence of varying concentrations of the test compounds. Viral cytopathicity or plaque formation was recorded as soon as it reached completion in the control virus-infected cell cultures that were not treated with the test compounds. Antiviral activity was expressed as the $\mathrm{EC}_{50}$ or concentration required to reduce virus-induced cytopathogenicity or viral plaque formation by $50 \%$.

Anti-HIV Activity Assays. Inhibition of HIV-1(IIIB)- and HIV-2(ROD)-induced cytopathicity in CEM cell cultures was measured in microtiter 96-well plates containing $\sim 3 \times 10^{5} \mathrm{CEM}$ cells/mL infected with 100 CCID50 of HIV per milliliter and containing appropriate dilutions of the test compounds. After 4-5 days of incubation at $37^{\circ} \mathrm{C}$ in a $\mathrm{CO}_{2}$-controlled humidified atmosphere, CEM giant (syncytium) cell formation was examined microscopically. The $\mathrm{EC}_{50}(50 \%$ effective concentration) was defined as the compound concentration required to inhibit HIV-induced giant cell formation by $50 \%$.

Anti-Moloney Murine Sarcoma Virus (MSV) Assays. The inhibitory effect of the test compounds on MSV-induced transformation of murine embryo fibroblast $\mathrm{C} 3 \mathrm{H} / 3 \mathrm{~T} 3$ cell cultures was examined microscopically at day 6 post infection. MSV was added at 75 focus-forming units to monolayer cell cultures in 48-well microtiter plates.

Cytostatic Activity Assays. All assays were performed in 96-well microtiter plates. To each well were added $(5-7.5) \times$ $10^{4}$ cells and a given amount of the test compound. The cells were allowed to proliferate for $48 \mathrm{~h}$ (murine leukemia L1210 cells) or $72 \mathrm{~h}$ (human lymphocytic CEM and Molt4/clone 8 cells) at $37^{\circ} \mathrm{C}$ in a humidified $\mathrm{CO} 2$-controlled atmosphere. At the end of the incubation period, the cells were counted in a Coulter counter. The IC50 (50\% inhibitory concentration) was defined as the concentration of the compound that inhibited cell proliferation by $50 \%$.

Acknowledgment. We thank Science Foundation Ireland (Grant 05PICAB802) and the Concerted Actions of the K.U. Leuven (GOA 10/014) for financial support for this work. We also thank Tom O'Mahony and Sinead Milner for their help with the HPLC, and Mrs. Leen Ingels and Lizette van Berckelaer for excellent technical assistance. We also thank the Johnson-Matthey Company for their loan of rhodium(II) acetate.

Supporting Information Available: ${ }^{1} \mathrm{H},{ }^{13} \mathrm{C},{ }^{31} \mathrm{P}$ NMR spectra of the key compounds from Table 2, 3, 4 and Schemes 9 and 11 are included. This material is available free of charge via the Internet at http://pubs.acs.org. 